\title{
NBS
}

PUBLICATIONS

\author{
NBSIR 82-2602
}

\section{Experimental Evaluation of Circulation Loop Drain and Vent Plumbing Modifications for Building Rehabilitation}

U.S. DEPARTMENT OF COMMERCE

National Bureau of Standards

National Engineering Laboratory

Center for Building Technology

Washington, DC 20234

November 1982

Issued December 1982

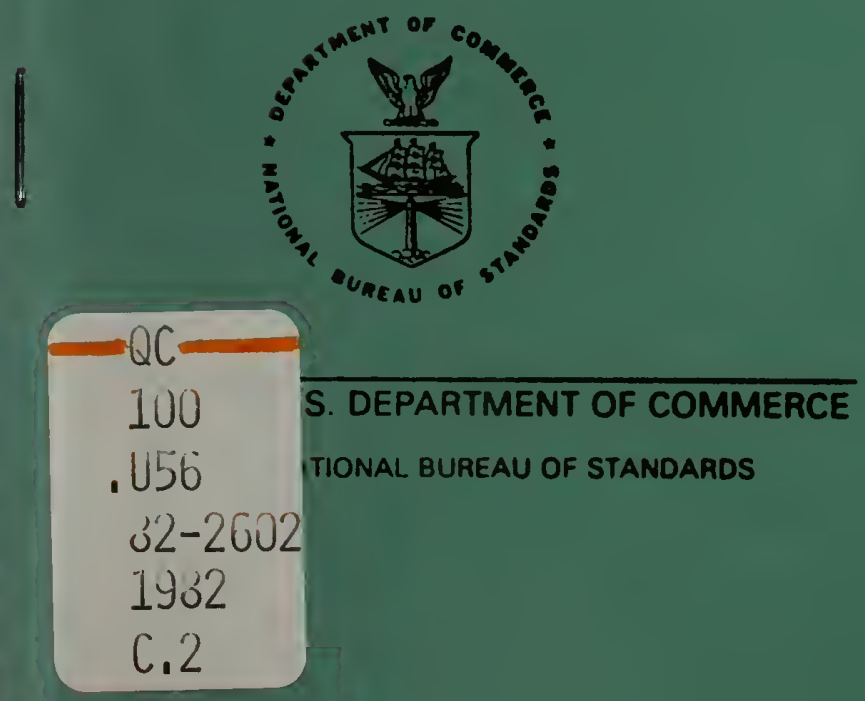





\section{EXPERIMENTAL EVALUATION OF CIRCULATION LOOP DRAIN AND VENT PLUMBING MODIFICATIONS FOR BUILDING REHABILITATION}

Fred Winter

Lawrence Galowin

U.S. DEPARTMENT OF COMMERCE

National Bureau of Standards

National Engineering Laboratory

Center for Building Technology

Washington, DC 20234

November 1982

Issued December 1982

U.S. DEPARTMENT OF COMMERCE, Malcolm Baldrige, Secretary NATIONAL BUREAU OF STANDARDS, Ernest Ambler, Director 



\section{ABSTRACT}

Rehabilitation or modernization of existing buildings frequently imposes increased loads on the plumbing water supply and drainage system. The requirement for venting in U.S. practice is intended to prevent trap seal loss from exceeding values prescribed in model plumbing codes. The vent piping in older bulldings may be marginal for retrofit under code requirements for new construction with the same or increased numbers of fixtures and devices installed into the plumbing system.

An experimental laboratory investigation of a "circulation loop" modification to a drain-waste-vent (DWV) system was conducted to determine the change in performance. An experimental evaluation of the performance of the modified system and a conventional system were undertaken for a variety of simulated wastewater-loads with various plumbing fixtures and multi-story soll stack loads. The performance parameters considered were trap seal failures, backflow, and the siphonic action of the water closets. Also, the dynamic responses to pressure excursions and air flow rates in the branches were measured. Both systems were tested to the limiting condition for single-stack performance over a range of alr flow rates into the soll and vent stack.

The circulation loop system was found to decrease the pressure difference in the upper a portion of the soil stack, and to provide limited benefits in reducing trap seal fallures and fallure due to reduced siphonic action in the lower level water closets. With vent valves open, both the conventional and modified loop systems provided satisfactory venting except at the highest loads. Additional research should be undertaken to develop methods for sizing the soll stack and vent connection fitting connection to the circulation loop. Further testing should also be done with small regulated air flows into the vent stack.

Key Words: Innovative venting; plumbing; plumbing renovation; rehabilitation; vents for plumbing. 


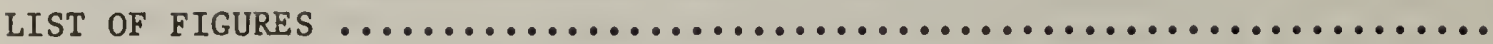

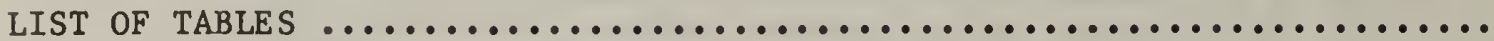

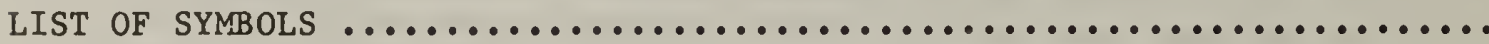

1. INTRODUCTION $\ldots \ldots \ldots \ldots \ldots \ldots \ldots \ldots \ldots \ldots \ldots \ldots \ldots \ldots \ldots \ldots \ldots \ldots \ldots \ldots \ldots \ldots \ldots \ldots . . \ldots \ldots$

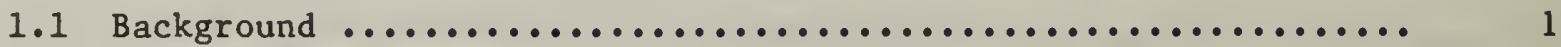

1.2 Vent System Requirements $\ldots \ldots \ldots \ldots \ldots \ldots \ldots \ldots \ldots \ldots \ldots \ldots \ldots \ldots \ldots \ldots \ldots$

2. PRESSURES IN VENTING SYSTEMS $\ldots \ldots \ldots \ldots \ldots \ldots \ldots \ldots \ldots \ldots \ldots \ldots \ldots \ldots \ldots \ldots . \ldots \ldots$

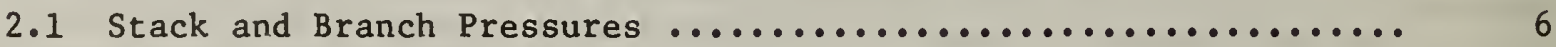

2.2 Vent Circulation Loop Modification ...................... 8

3. VENT CIRCULATION LOOP TEST PROGRAM AND RESULTS ............... 10

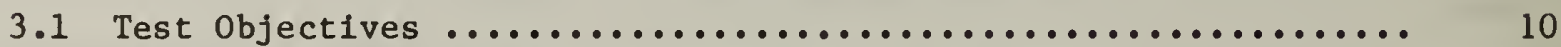

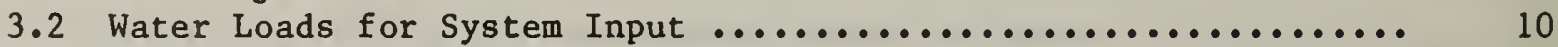

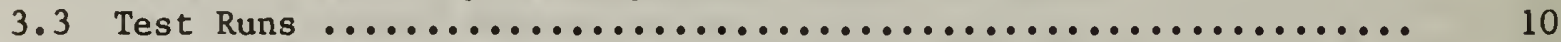

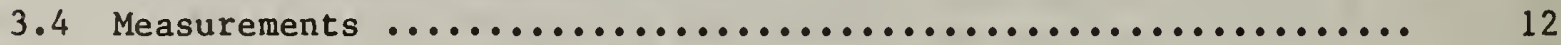

3.5 Test Results and Interpretation of Data $\ldots \ldots \ldots \ldots \ldots \ldots \ldots \ldots \ldots \ldots . . \ldots$

4. DISCUSSION OF TEST RESULTS ............................. 14

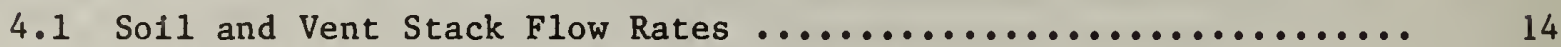

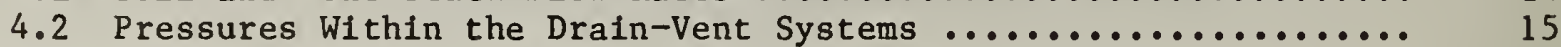

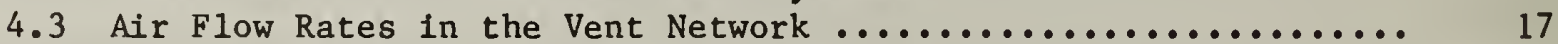

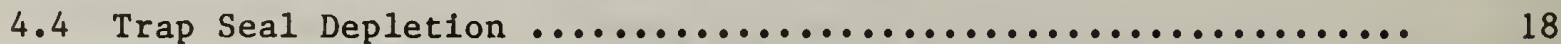

4.5 Trap Seal Depletion and Pressure Excursion ................. 19

4.6 Effect of Variations in the Vent Stack Air Flow on the

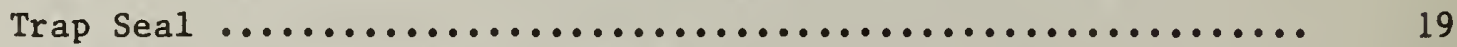

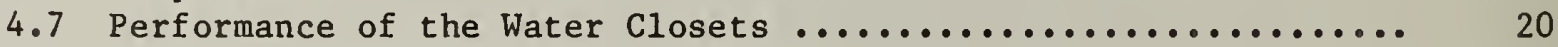

5. CONCLUSIONS AND RECOMMENDATIONS $\ldots \ldots \ldots \ldots \ldots \ldots \ldots \ldots \ldots \ldots \ldots \ldots \ldots \ldots \ldots \ldots . \ldots \ldots$

6. REFERENCES ............................................ 23

APPENDIX 1 - RESULTS OF ONE CYCLE TEST RUN ..................... 53

APPENDIX 2 - COMPARISON OF TEST RESULTS AMONG RUNS ................ 64 


\section{LIST OF FIGURES}

Page

Figure 1. Diagram to illustrate hydraulic and pneumatic conditions in an discharge stack

F1gure 2. Schematic diagram for modifled vent one-pipe system of drainage in buildings .............................

Figure 3. Pressure diagram for stack with vent system [8] ..........

F1gure 4. Pressure diagram for stack without a vent system for a steady

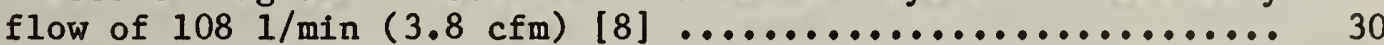

Figure 5. Vent header network computer model ................... 31

Figure 6. Conventional drainage system and the vent circulation loop .. 32

Figure 7. Flow characteristics of typical water closets and bathtubs .. 33

Figure 8. Identification of the input elements ................. 34

Figure 9. Identification of the measurements and location .......... 35

Figure 10. Water and total air flow rates in the soil stack (vent stack closed)

Figure 11. Soil stack water flow rates and the soll stack and vent stack air flow rates for the circulation loop and conventional system (various valve settings)

Figure 12. Pressures in branches with vent valves closed and open with soil stack downflows and no water closets discharged .......

Figure 13. Pressures in branches with $2.531 / \mathrm{s}$ (40 gpm) soil stack downflow and one water closet discharge, vent valves closed and open $\ldots \ldots \ldots \ldots \ldots \ldots \ldots \ldots \ldots \ldots \ldots \ldots \ldots \ldots \ldots \ldots \ldots \ldots \ldots \ldots \ldots$

Figure 14. Branch pressures with $2.531 / \mathrm{s}(40 \mathrm{gpm})$ and downflow one water closets discharged, vent valves closed and open .......

Figure 15. Branch pressures with $5.051 / \mathrm{s}(80 \mathrm{pm})$ and all water closets

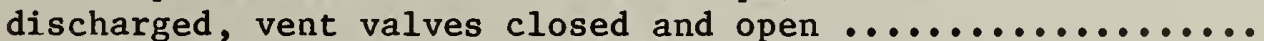

Figure 16. Mean branch pressures as a function of time over three

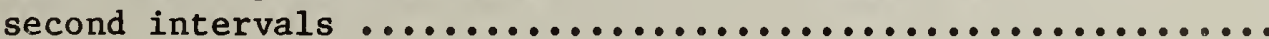

Figure 17. Accuracy attained in measuring the air flow rates at junctions in the flow net by hot wire anemometry .......... 


\section{LIST OF FIGURES (Continued)}

$\underline{\text { Page }}$

Figure 18. Distribution of air flow rates in the vent stack and the vent branches for several vent valve settings .................

Figure 19A. Comparison of the air flow rates and pressures during the

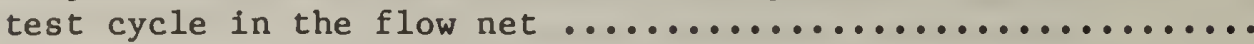

Figure 19B. Comparison of the air flow rates and pressures during the

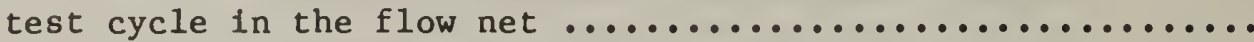

Figure 20. Depletion of traps 1, 2, and 3 as a function of the soil stack flow rates (no fixtures active) for the circulation loop and the conventional system $\ldots \ldots \ldots \ldots \ldots \ldots \ldots \ldots \ldots$

Figure 21. Depletion of traps 4 and 5 as functions of the soil stack flow rates (no fixtures active) for the circulation loop and

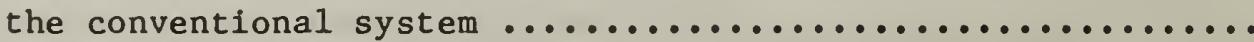

Figure 22. Trap seal depletions for the circulation loop and conventional system for 2.53 and $5.051 / \mathrm{s}(40$ and $80 \mathrm{gpm}$ ) of soll stack flow with vent valves closed

Figure 23A. Trap seal depletions and the corresponding static pressures in the drains as a function of the soll stack flow rates for the circulation loop and the conventional system ...........

Figure 23B. Trap seal depletions and the corresponding static pressures in the drains as a function of the soll stack flow rates for the circulation loop and the conventional system ...........

Figure 23C. Trap seal depletions and the corresponding static pressures in the drains as a function of the soll stack flow rates for the circulation loop and the conventional system ...........

Figure 24. Trap seal depletions for traps 1,3, and 5 for a soil stack flow rate of $4.12 \mathrm{l} / \mathrm{s}$ ( $65 \mathrm{gpm}$ ) with various vent stack valve

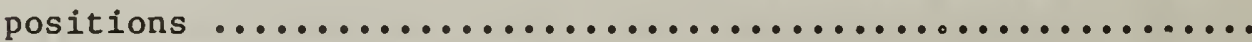


Table 1. Stze and lengths of vents ........................... 24

Table 2. Examples of marginal venting ......................... 25

Table 3. A typical computer output from a test run ............... 26

Table 4. A computer output of mean values for 12 test runs .......... 27

Table 5. Performance of the water closets in the drainage system (conventional) ................................... 28 


\section{LIST OF SYMBOLS}

$B_{K}$ bathtub simulation computer control code indicator

D pipe diameter

f plpe friction factor

g gravitational constant

$h_{\text {s }}$ suction head

k pressure loss coefficlents (gener1c)

\& p1pe length (equivalent)

$Q_{a}$ air flow rate

Q test load flow rates in the soll stack (see p. 10)

$\mathrm{WJ}_{\mathrm{J}}$ water closet computer control code Indicator

$V_{\mathrm{L}} \quad$ vent valve computer control code indicator

$\Delta$ mass flow balance error (percent)

$T, F S, F V, P_{1 J}, P_{k}, F_{1 J}$ Recorded data designations (see p. 11)

Note on metric conversion:

Plumbing codes and design guldes have not adopted metric units, therefore metric units are shown in the report along with common units (1n parentheses). 


\section{INTRODUCTION}

\subsection{BACKGROUND}

Rehabilitation of existing buildings may require only the renovation or repair to existing systems or may extend to complete replacement with new systems and components. It is generally desirable to reuse intact existing drainage, waste and vent (DWV) piping in the bullding especially when existing structural or architectural elements in the building pose extensive physical constraints to the installation of new DWV piping. In order to facilitate rehabilitation practices concerned with the plumbing system, the determination of the condition and capacity of the existing DWV piping in the building must be made. Such determinations are required to: (a) assess the suitability for reuse of the existing installation; (b) assess the potential for expansion to allow increase loads; (c) provide local jurisdictional authorities with the information for evaluating the rehabilitation project. Inspection procedures, documentation, testing and general methods for estimating plumbing system capacity are described in the Rehabilitation Guldelines [1] published by the Department of Housing and Urban Development (HUD).

Circumstances which may require new construction criteria to be applied to a rehabilitation project are:

- A rule in effect in the jurisdiction requiring upgrading when the building is being repaired or improved, e.g., compliance is triggered by a local 25-50* percent rule for repair and improvement of existing residential buildings.

- A requirement when there is change of use or occupancy (e.g., from one- and two-family dwelling to apartment building, office building to apartment building, etc.).

- Deterioration of the existing system is extensive and repairs or upgrading will not bring the system into compliance for sizing.

There are several problems in applying new construction requirements to renovation situations:

(a) Extensive and costly structural and finish work may be necessary if the plumbing system is to be made accessible for modification.

(b) Pipe size, connections, use of wet venting, and vent location do not comply with current code provisions (although, existing vent systems may provide for adequate health and safety as installed and used).

* The 25-50 rule is frequently applied as the percentage of costs to value in rehabilitating projects above which new building requirements must be satisfied. 
(c) New vents and drainage line installations may be constrained by limited available space and/or the existing configuration of the piping system.

(d) Proposed use or modification to existing DWV systems requires building and plumbing officials to apply judgment without the ald of complete technical guidelines.

The Guidelines [1] do not provide methods to determine adequately the load capacity limits of the plumbing system and evaluate it for expansion of the loading patterns.

The DWV system collects effluent water from the fixtures and drains and conveys it to the public sewer or onsite treatment sites. The piping system for collection and transmission of wastes can transmit sewer gases and foul odors back into the inhabitable areas of bulldings unless water traps near drain outlets are provided to prevent escape of sewer gases. During the discharge of the various fixtures into the drainage system, pressure excursions are induced by the gravity driven wastewater flow. The concern is focussed on the idle traps since the trap seals of active fixtures will be replenished by water discharging from the fixtures. Reduced pressures may deplete the trap seal by withdrawing water. Positive pressures causes the column of water in the idle trap to rise (on the fixture side) and can cause water from the trap to be spilled after removal of the load and thereby deplete part or all of the trap seal. Partial trap seal losses reduce the level of protection afforded by the trap seal against the passage of noxious gases from the sewer into the living space. Large pressure excursions are therefore undesirable. To reduce the pressure fluctuations in the drain lines for the preservation of the integrity of the trap seal, vents are provided as a means of supplying air into the system.

The vent system also serves to relleve pressures in the soll stack as well as to individual traps. The partially-filled drains and branch vent piping passages from the vent system are connected to the stack and supply supplementary air to modify the soll stack pressure. The suction or positive pressures in the stack can strongly influence the discharge performance characteristics of fixtures and appliances in the gravity driven drainage system. The siphonic discharge action of water closets are especially dependent on the pressure conditions.

\subsection{VENT SYSTEM REQUIREMENTS}

A properly designed plumbing vent system provides adequate pressure relief when wastewater discharge loads are placed upon the drainage system. The pressure relief provided at the trap is dependent upon pipe friction (roughness), pipe connections, fitting losses, changes in pipe sizes, and configurations of pipe bends. The relationships between the air flow rates, and pressure levels adjacent to the trap as a function of the waste loading must be known to size the vent system piping. The model plumbing codes require that each fixture trap shall have a water seal of not less than $50 \mathrm{~mm}$ ( 2 in) nor more than $100 \mathrm{~mm}$ ( 4 in) (as defined in the model codes), except where a deeper seal is required 
by the plumbing official for special conditions. The codes $[2,3,4,5]$ are also in agreement that venting systems are generally required and shall be designed and installed so that trap seals shall not be subjected to a pneumatic pressure difference of more than one inch of water pressure under design load conditions. The selection of size and length of vent piping requires information about the size of the soll and/or waste stack and the fixture units (the probabilistic parameter for frequency of usage and time period of fixture discharge for the loads connected to the stack). The codes provide tabulations, (e.g., table 1) from which the vent pipe diameter can then be selected for known lengths of the vent.

The determination of condition, integrity, and capacity of the installed DWV system in proposed rehabilitation projects requires procedures set forth in [1]. The evaluation for proposed expansion of plumbing utility services within a building provides little flexibility (unless the existing system was over designed) since the accepted references are the current model plumbing codes for new installations. Alternative solutions applicable to various DWV installation problems for residential rehabilitation are not documented to aid the local jurisdiction in approving nonconventional installations. In the case of venting requirements, the basis for sizing was established by Wyly and Eaton [6] and adopted (with some modification) by all of the model codes [2,3, 4,5]. The conservative assumptions by Wyly and Eaton resulted in design recommendations leading to oversize vent pipe systems. The research by Lilywhite and Wise [7], Chakrabarti [8] and by the authors herein confirms that the major portion of the air is supplied through the main drainage stack. The laboratory testing of trap seals with reduced size venting systems for hospitals (in table 1) has shown that the tabulations presented in current plumbing code provisions for sizing vents are overly conservative [9]. In that study the limits of vent pipe lengths for given dlameters were found to be up to 30 percent greater.

In rehabilitation projects the reuse of the installed plumbing system is desired to reduce construction time and provide cost savings. The estimated hydraulic drainage system capacity may be increased provided the venting maintains pressures close to atmospheric so that (1) the trap seals will not be excessively depleted, and (2) the discharge performance of fixtures, 1.e., the siphonic action in the water closet, is not serfously degraded. The trap failure modes for which protection is required [1] are:

- Self-siphonage - seal depletion due to siphonic action by the discharge of the fixture to which the trap is connected;

- Induced siphonage - seal depletion due to siphonic action by discharge of fixtures other than the one to which the trap is connected;

- Blowback - emission of water, suds, air, or sewer gas into the fixture or the inhabited area of a bullding through the fixture trap; and

- Cross-flow - movement of wastewater from the trap or branch drain of an operating fixture into the trap or branch drain of an idle fixture. 
The first pode of fallure, self-siphonage, is a function of fixture and branch plping characteristics. Self-venting trap arms and branch drains can be deslgned to prevent self-siphonage through knowledge of the flxture discharge characteristics and correct plpe sizing and configuration. Induced siphonage, blowback, and cross-flow are prevented through correct venting design and installation. Protection of the DWV system utilizing individual fixture vents is an obviously expensive approach. Among more economical alternatives developed, tested, and comonly approved for residential bulldings are stack venting and wet venting. In stack venting, fixture traps are protected by venting provided through the (upper portion) soll or waste stack; this technique is allowable in low bulldings or for the top floors or high bulldings. het venting is a technique that uses the drain plpe itself for venting of selected fixture traps. In practice wet vents apply to single fixtures or groups of low discharge fixtures connected to a single horizontal branch.

For DWV systems that meet the initial requirements for renovation and reuse as deternined from onsite evaluation procedures (e.g., structural integrity, tightness, etc.) the 1ssue of the vent capacity limits for the proposed waste load patterns must be addressed. The sizing of the vent system to adequately satisfy increased loads requires calculation of the waste fixture units and the application of the vent sizing table of the appropriate code. Increase in the number of water using appliances and fixtures can be anticipated for renovated bulldings (with or without change of occupancy). Older bulldings generally have fewer restroom facilities and appliances than normally installed in newer buildings. For changes of occupancy facillties, such as additional kitchens, restrooms, and appliances w1ll have increased sanitary loads. In such situations the installed plumbing system may be found to offer "marginal venting capacity." Marginal venting is defined here to be that capacity of the vent size and length which is less than (by an arbitrary limit) the allowable minimum values or exceeds somewhat the maximum permissible found in the plumbing code tables.

Examples of marginal venting conditions are illustrated in table 2. It is assumed that satisfactory conditions for reuse and/or expansion of the existing DWV systen were determined following the procedures of [1]. The requirements of the proposed renovation are 1llustrated for two of many possible situations; in group I the maximum length of the vents exceed that allowed for the same number of fixture units connected; in group II, the fixture units connected exceed the allowable values (although the maximum length of vents by interpolation may not be exceeded). While the existing drainage system may be sized to satisfy additional hydraulic loading from the wastewater in the building the vent network nay not be adequate and construction of a new vent piping network could be required. The consideration to be addressed is whether the excess load requirements can be satisfled by modification of the DWV by an alternative acceptable approach without replacing the existing vent piping.

In this investigation, the DWV modification to eliminate marginal venting linitations was the addition of a vent circulation loop with interconnections to the soll and vent stack as described in section 2.2. A vent circulation loop provides for redistribution of waste loads into the soll stack and increases venting capacity by adding air storage volumes associated with the 
vent plplng network. The experiments were designed to determine the effectiveness of the modifications in limiting pressure excursions at the trap seals and providing satisfactory flxture drain performance. 


\section{PRESSURES IN VENTING SYSTEMS}

\subsection{STACK AND BRANCH PRESSURES}

The vertical drainage stacks and horizontal branch drains run partially full in correctly designed plumbing systems. The annular flow in vertical stacks entrains air within the core; the branch drains flow partially full with air above the liquid surface. The air flow and pressure distributions depend on the drag between the water and $a$ ir and on the frictional resistance of the components of the system. The air is discharged or ingested from the vents of the building drain and/or sewers, although a portion may recirculate and leave from the stacks. Research has been conducted to develop generalized schemes for calculation of maximum pressure excursions below and above atmospheric (figure 1 ) by combining theory with experimentally determined coefficients $[6,7,8,9,10]$. The present requirements for venting pipe sizes [6] to limit stack and branch drain pressure changes within a narrow band, $\pm 2.5 \mathrm{~mm}$ ( 1 in)* was based upon assumptions which may be questionable as a result of recent experimental data [8]. This is discussed in later sections of this report. Pressure excursions of $5 \mathrm{~cm}$ ( $2 \mathrm{in}$ ) in the stack results in the $108 \mathrm{~s}$ of $25 \mathrm{~mm}$ ( 1 in) from a filled trap seal in (commonly sized) traps constructed with a depth of $50 \mathrm{~mm}$ ( 2 in) at the "U-bend."

The methods of modifying pressure distributions in soil stacks have not been the specific subject of plumbing research investigations. However, experimental results of Wyly and Eaton [6] have shown that drain stacks which carry large wastewater flows and which are interconnected with vents have the peak suction and positive pressures as low as one half that of an unvented stack. The need for further research identified in that report (over 25 years ago) has only recently been addressed; it was recommended that:

"Further investigation of air flow in venting systems is required to obtain information on the flow and recirculation in complex venting systems .... applications of results from relatively simple systems may be unrealistic with respect to more complex systems ... (vent) pipe sizing could be effected if proper allowances for recirculation of air and height of fall of water in complex venting systems could be made."

Modifications for rehabilitation projects could include non-vented single stack systems which are widely accepted in Europe. Single stack installations are reduced in complexity since the entire vent piping network and interconnected branch elements are eliminated. The extensive use of such systems in the United States is not anticipated. The basis for predicting the maximum suction pressures in an unvented discharge stack follows the formulation by Wise [11] for the suction head, $h_{s}$,

$$
h_{s}=\frac{Q_{a}^{2}}{g D^{4}}\left[0.5+\sum k_{\text {bends }}+\frac{f_{\ell}}{D}+\sum k_{\text {inlets }}+1\right\rfloor
$$

* Pressures are expressed in height of water column, unless otherwise specified. 
where $Q_{a}$ is the air flow rate, $D$ the stack diameter, $g$ the gravitational constant, and the other factors are pressure 1088 coeficients. The equation indicates that the suction head is the summation of the pressure drop at entry to the stack, the pressure drop due to bends, the pressure drop in the piping (for the equivalent length) in the dry part of the stack, the sum of pressure drops across the discharging inlets, and the velocity head.

The application of the method to a partially vented drainage stack, (reported in [8]) figure 2, require additional equations to account for the air flow introduced at the branches (for $n$ junctions). The simultaneous equations for each air flow path with the overali continulty equation are then solved for the head 1088 ( $1 . e$, the suction pressure). The linear superposition of terms in all equations neglects $1088 e s$ which occur due to air and water flows mixing at connections and fittings. The lack of agreement between experimental results and predictions have generally been attributed to this basic assumption. In addition, the results of [8] includes the equations derived for the calculation of water film thickness in the stack and the terminal velocity of the soil stack annular water flow (the shear induced driving force for the air ingestion). Typical experimental data for the plumbing systems investigated in [8] are reproduced in figures 3 and 4. These figures illustrate the change from suction to positive pressures, relative to the atmospheric pressure, at different levels in a building and in the test tower.

For fully vented systems (venting of all fixtures on a branch connected to the soll and vent stack) a more complex set of equations are necessary. Two separate, although similar pipe network analysis methods (multi-path and loop closure), figure 5, have been developed for computer based numerical solutions of the equations [9]. Those schemes, analogous to an electrical network analysis method, were applied to the plumbing for each floor of a hospital building interconnected with interstitial space vent headers and long horizontal drains that are connected to the vertical vent and soil stacks. The complete flow and pressure loss analysis at the vertical stacks could then be handled by a means similar to that described by Wise, above, or proposed in [6] for junctions of drainage stacks with horizontal branches. The methods are limited in their accuracy to predict pressures and air flow rates due to the lack of loss coefficients for sanitary fittings and roughness factors for piping of various materials. Generalized methods of solution for single-component flow (water or air) in pipe connected networks are discussed in [12] and [13]; two component flows (air and water) are not addressed there.

In summary, the basic physical principles of air flow ingestion into the plumbing system and the resulting pressures are known. Limited experiments have provided a narrow empirical basis for calculations under some loading conditions and configurations. There was a need to conduct additional experiments to provide data for the performance of other than the conventionally installed system.

The relatively well established and simpler single pipe non-vented European installations should be considered, because of potential economic benefits, as another alternative in selecting plumbing renovations with limited waste loads. 


\subsection{VENT CIRCULATION LOOP MODIFICATION}

Alternative solutions for handling DWV problems in residential rehabilitation are required. After the integrity to perform the sanitary functions have been found to be satisfactory the capacity of the existing DWV system for the proposed occupancy loading patterns must be determined. When the analysis ind1cates ( 1 ) the existing system provides limited venting capacity as defined by current codes, or (11) there is restricted vent capacity for upgrading services (which may include expansion of the plumbing system), then methods for supplementing the marginal venting must be considered. Several methods are possible:

a) Apply vent connections only to those branch drain fixtures (existing or new) which are likely to experience greatest suction loads on the trap. Long branch drains which are subjected to self siphonage due to full bore flow would be logical locations for such connections.

b) Modify the drain piping to incorporate single pipe drain systems (as in the European practice) where tolerable loading limits are anticipated.

c) Adapt separate portions of the drain system to vacuum drainage or small pressurized drain piping where expanded sanitary facilities are added to the system. This portion of the system essentially becomes a new DWV system while retaining the existing system to handle only a fraction of the loading.

d) Modify the drain and vent pipe configurations to alter either the soil stack pressure distribution or to provide expanded volumetric capacity (as a reserve air source) to supply the branch vent lines.

The first three $(a, b, c)$ are not in accordance with conventional U.S. practices and would have difficulty in gaining acceptance. The method (d) introduces a variation of current practice but retains the generally accepted approach for venting connected systems.

An experimental evaluation of a modifled vent drainage stack system designated as "a circulation loop vent system" was conducted. Following (d), the circulation loop vent system provides increased volumes to the vent network, alters the drain stack load input and redistributes the pressures in the soll stack. The conventional and the circulation loop vent systems are shown in the schematics in figure 6. The expansion of facilities beyond the line A-A 1llustrates an example of increased loads on the plumbing system.

The laboratory DWV system included $75 \mathrm{~mm}$ ( $3 \mathrm{in}$ ) soll stack, loops, and drains while the vent stack and vent branches were $50 \mathrm{~mm}$ ( $2 \mathrm{in}$ ) in diameter. The systein tested simulated the plumbing in a three-story building with soil and vent stack with water closets and simulated bathtubs, as shown. A water tank above the third level provided water flow into the system to simulate wastewater loadings from the upper storles of a larger bullding. The system was tested in two phases. In the first phase, the assembly included the circulation loop vent network. Two configurations of the circulation loop vent system 
were included in the testing - one a double-story loop and the other a singlestory loop. The longer double-story loop had a larger alr volume with greater potential for altering the soll stack pressures as well as the abllity for providing greater length for diversion of waste loads from the soil stack. The supplementary venting attachment to the loop from the vent stack provided a path to the atmosphere. All vent plpes were of the same dlameter in the experImental rig, however, the connecting vent branches may be of smaller diameter plpe. The circulation loops are not necessarily required to be located in close proximity to the soll stack as was the case in this experiment. That provides for more flexibility in design of the renovation for added sanitary facilities. In the second phase, the elements of the c1rculation loop were removed and the network converted to a conventional plumbing system. Each configuration was subjected to identical wastewater loads in various combinations of fixture loadings to enable comparison and assessment of the proposed circulation loop performance. 


\section{VENT CIRCULATION LOOP TEST PROGRAM AND RESULTS}

\subsection{TEST OBJECTIVES}

The objectives of the tests were to determine:

a. the effectiveness of changing the capacity of an existing drain-vent system by stack and venting connections to provide trap seal protection at increased wastewater loadings.

b. the allowable increase in wastewater hydraulic loads as a result of the modification.

c. the trap seal depletions under the simulated wastewater loadings.

d. the air flows and pressure excursions in critical areas adjacent to the trap seals and soll stack fittings.

e. the extent to which the siphonic action of the water closet is affected by pressure excursions in the stack.

\subsection{WATER LOADS FOR SYSTEM INPUT}

The loads were provided by tanks simulating bathtubs, water closets and a soll stack water supply tank. The bathtubs were simulated by containers calibrated to deliver a water flow to the drains of $0.885 \pm 0.13 \mathrm{l} / \mathrm{s}$ (14 $\pm 2 \mathrm{gpm}$ ). Actual water closet flxtures were used. The soll stack water supply tank, installed to simulate wastewater flows from the upper stories, was capable of delivering water in the range of $0-5.35 \mathrm{l} / \mathrm{s}(0-85 \mathrm{gpm})$. The flow from the tank and to the soll stack was over a circular weir such that an annular flow would be rapidly established in the soll stack. Typical flow rates for water closets and bathtubs are shown in figure 7. Bathtubs are characterized by having a relatively constant flow rate that are in the range of $.82-1.09 \mathrm{l} / \mathrm{s}$ (15-20 gpm) (depending on the nominal diameter of their outlet) while water closets have a higher peak flow rate range $(1.09-2.19 \mathrm{l} / \mathrm{s}(20-40 \mathrm{gpm}))$ which is established rapidly and then falls sharply after 5 seconds. The load system consisted of two water closets back-to-back on the first and second levels, two bathtubs (also on the first and second levels), and one water closet and one bathtub on the third level. Valves were inserted in the vent stack and the vent branches so that the air flow from the vent stack to the vent network could be varied or eliminated entirely (see figure 8 ).

\subsection{TEST RUNS}

Figure 8 shows the circulation loop vent assembly tested in the laboratory with the identification of the major elements in the system. A test run consisted of a combination of the following flow parameters:

- Flow rate to the soll stack (see figure 8 for identification of input elements) 
$Q_{i}=0,1.09,2.19,3.28,4.38 \mathrm{k} / \mathrm{s}(20,40,60,80 \mathrm{gpm})$

- Water closet flushing, $\mathrm{W}_{\mathrm{J}}$, where

$$
\begin{aligned}
J= & 1 \text { no W.C. } \\
& 2 \text { - W.C. } 1.1 \\
& 3 \text { - W.C. } 1.1,1.2 \\
& 4 \text { - W.C. } 1.1,2.1,3.1 \\
& 5 \text { - W.C. All }
\end{aligned}
$$

- Bathtubs active, $B_{K}$, where

$$
\begin{aligned}
K= & 1 \text { - no tub } \\
& 2 \text { - one tub } \\
& 3 \text { - two tubs } \\
& 4 \text { - three tubs } \\
& 5 \text { - all tubs }
\end{aligned}
$$

- Vent valves closure, $V_{m, L}$, where

$$
\begin{aligned}
& L=1 \text { valves closed } \\
& L=2 \text { valves partially open } \\
& L=3 \text { valves fully open }
\end{aligned}
$$

and for each of the four valves shown, $m=1,2,3,4$.

The data acquisition system and the computer interface provided the capability of recording 300 consecutive readings for each station (flow rates and pressures). The data recorded also provided a resource base for future study of the details of the dynamic response of the system.

Initial settings of manually operated control valves were made prior to the startup and the balance of the test run was fully automated by sending the proper signal information to the automated control system with designated codes from the control console.

The total time for each run was 30 seconds during which time stack flow, $Q_{i}$ (if non-zero) was continuously flowing from the start. For the active bathtubs $B_{K}$, the flow started at the beginning of the run. When water closets were active in the run, their operation started ten seconds after the start of the run to permit equilibrium conditions to develop for other flows. Data scans were made and recorded at ten readings per second to the end of each test ( 30 seconds). The data processing consolidated the data into ten groups of three second intervals ( 30 readings per group) and calculations were made to yield minimum, maximum, mean, and the maximum rate of change between two consecutive data points for the measurements at each instrumented location. The values for depth of the trap seals were read only twice; before and after the run in order to obtain the trap seal depletion after the period of the entire test run. Determining the trap seal dynamic response (oscillation) was not within the scope of this project. 


\subsection{MEASUREMENTS}

Figure 9 indicates the location of the instruments and the parameters measured for each test run, which were as follows:

T Water flow rate to the soll stack

FS Air flow rate intake to the soll stack

FV Alr flow rate intake to the vent stack

$P_{1 J} \quad$ Static pressure at designated station; $1=$ floor level, $J=10 c a t i o n$

$\mathrm{PT}_{\mathrm{k}} \quad$ Trap seal depletion for the traps connected to the simulated bathtubs

$F_{1 J}$ Alr flow rates in the vent stack and vent branches at the designated station; 1 = floor level, $\mathrm{J}=$ location

In addition, temperature probes were connected at each level in order to correct the vent air flow measurements.

Data scans ( 10 readings per second) included all the designated stations except for the air flows in the vent branches. Air flow measurements ( $F_{1 J}$ ) using hot-wire anemometers were made in each test run at the same scan rate but at only eight selected locations (of the fifteen avallable) in the vent network.

\subsection{TEST RESULTS AND INTEPRETATION OF DATA}

Table 3 is a typical computer output of a test run. The following information is shown:

- Test conditions, 1.e., Identification of the system, vent valve position, the water closets and tanks operated during the cycle and the nominal flow rate from the soll stack supply tank.

- Trap seal depletion at the simulated bathtubs (where zero indicates no depletion).

- Mean, maximum and mimimum values of the water flow rates from the soll stack, and air flow rates to the vent and soll stacks.

- Pressure and air flows as recorded at the designated stations.

The eight hot wires were installed at selected locations in the vent network. As shown in the sketch below, the measurements provided three measured air flows (two entering and one leaving) at the junction $J_{1}$. This feature provided details of internal vent piping flow; the measurements also provided the supplementary data for the vent stack volumetric flow rate analysis. Since the experimental laboratory configuration closely simulated that of an actual installation, no provisions were made to establish inlet pipe development lengths (upstream of the hot wires) to fulfill the usual requirements for accuracy of such readings. The accuracy of the air flow rates measured at low Reynolds numbers were generally poor (compared with the higher Reynolds numbers). Consequently closing the mass flow balance equations at junctions and fittings had large errors (see discussion in section 4.3). The deviation of the 
mass flow balance (error) was based upon absolute value of the percentage error, $\Delta$ percent, as shown below.

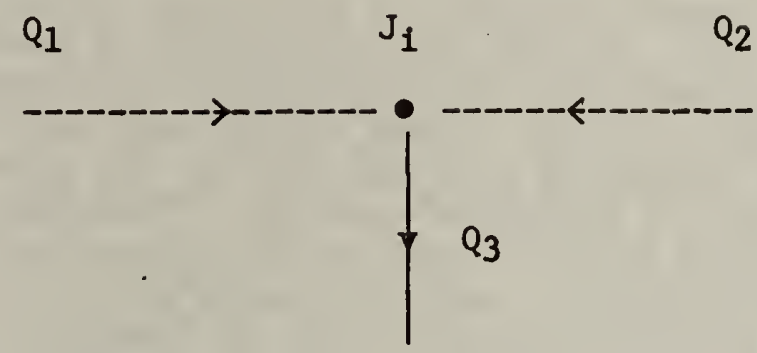

$$
Q_{1}+Q_{2}-Q_{3}=|\Delta|
$$

or

$$
\Delta \%=\frac{|\Delta|}{Q_{3}} \times 100
$$

Table 4 is a summary of 12 test runs where only the mean values of the test results are displayed; reduced data for three separate groups of test conditions are presented. Each group contains four independent tests with nearly identical input conditions. It is noted that the test results within each group did not vary appreciably which indicated that the tests were repeatable.

Appendices 1 and 2 present summary tables of data for the tests with various loading conditions of soll stack flows, operation of various fixtures, and valve settings (for vent air control) including the limiting case of single (soil) stack conditions. 


\section{DISCUSSION OF TEST RESULTS}

The vent plpe system, branch drains, and soll stack represent a complex plping network which acts in a manner similar to an ejector-driven air pump, where the water in the soll stack "drives" the system. In a simple ejector, the acceleration of the full bore flow of water through a contracting area section reduces the static pressure in the stream and thereby induces suction on an interconnecting branch (generally at a junction in the plane of the minimum area) In accordance with the Bernoulli equation. The complex piping of the drain system with numerous branch drains for wastewater and branch headers to the vent stack introduces multiple air flow paths with possible recirculation. The overall operation follows the performance of ejectors, 1.e., an Increase in water flow rate 18 followed by an increase in air flow rate.

In analyzing the test results similarities with other investigations $[6,8]$ were noted. For example, the total air flow 1ncreases to a level that appeared to be limited by the overall system resistance to air induction (due to pipe sizes, roughness of plpe walls, fitting losses and changes of areas at pipe branch points). No studies have been reported which demonstrate the controlling parameters or quantify the interdependence between the variables. In past investigations, the levels of air flow rates as a function of wastewater loads have been determined only over a very small range of vent and soll stack sizes. The levels of flow rate values in the vent and soll stack have been found to be generally comparable. The limiting levels of flow through the system may be governed by the downstream exit condition where the stack joins an elbow turning the water flow into the bullding drain which may cause full bore flow; some backup into the vertical so11 stack occurs and has been 1dent1fled as one cause of the increased pressure (above atmospheric) in the lower part of the vertical soll stack and possibly the lower part of the vent stack. In this lower region the air ingested must either be conveyed out to the bullding drain vent or the vent stack.

In this test series the water supply tank with an overflow inlet weir (without any flow guide to initially establish the annular stack flow) caused strong pressure reductions in the stack due to: (a) a vena contracta that decreases the cross-sectional area for the incoming air, and (b) an acceleration length of up to $3 \mathrm{~m}(10 \mathrm{ft}$ ) required for the water to attain near-terminal velocity. Both effects caused reduced suction pressures at the top of the soll stack; such pressure excursions exceeding that normally anticipated in a mid-level stack location of a multi-story building with loads from upper floors.

Specific samples of the data are shown here for soll stack and air vent stack flow rates, air flow rates within the vent pipe network, trap seal depletion and performance of the water closets. Additional data from the experiments are shown in the appendices.

\subsection{SOIL AND VENT STACK FLOW RATES}

The alr flow rates in the soll stack for the circulation loop and conventional systems as a function of the soll stack water flow rate are shown in figure 10 
for the vent stack valves closed. Alr flow rates as a function of the soll stack water flow rate 1 s shown for both systems in figure 11 with the vent stack valve open. There were no fixtures operating during any of these tests.

As seen in figure 11 the soll stack contribution to the total alr flow rate 1 s appreclably greater than the contribution from the vent stack. These results are simflar to other tests $[6,8]$ where vent to soll stack a1r flow rate ratios vary from $1: 3$ to $1: 6$. In previous studies leading to vent pipe sizing (now embodied in the plumbing code tables) a constant ratio was assumed for the vent to soll stack alr flow rates. The effects of varying the vent to soll stack alr flow ratio on vent pipe sizing in accordance with the test results requires further 1nvestigation. The alr flow rates in the vent stacks of the conventional system and circulation loop were simflar. The larger circulation loop piping interconnections possibly permits the air supply capacity of the clrculation to be distributed differently; however, the flows through the systems are comparable over the range tested. It w111 be noted in the following sections that the alr flow rate varlations follow directly with the changes of pressures within the system. Therefore, the air flow rate values alone do not indicate the performance of the system but may provide an indication of the overall resistance (or ejector efficlency) parameter when coupled with the pressure drop.

\subsection{PRESSURES WITHIN THE DRAIN-VENT SYSTEMS}

The pressure data obtalned at the transducer stations in the vent stack, branches, and drains provide detalled information concerning the pressure distributions in the clrculation loop and conventionally vented systems. The pressures in the branch vent arm at the closest connection of the vent and drain stack were Indicative of the pressures in the vertical pipes (vent and soil stacks).

Figures 12, 13, 14, 15, and 16 show data from several of the test runs. The plotted points are grouped in the sequence $P_{J K}$ which represent the pressures in the vent branch $(\mathrm{K}=2)$, the drain branch $(\mathrm{K}=1)$, and furthermost arm of the loop $(\mathrm{K}=3)$ at each level $\mathrm{J}$, where $\mathrm{J}=1,2$, or 3 for first, second and third level in the test tower (see figure 9). The pressure excursion value of $\pm 2 \mathrm{~mm}$ $\mathrm{Hg*}$ is approximately the limit value for acceptable system performance (o $\bar{f} \pm 1$ inch water). For the conventional system with vent valve open or closed and with or without water closet operation, the pressure variation in the soll stack from top to bottom was from below atmospheric to nearly or above atmospheric. For the circulation loop system with and without water closet operation, the suction pressures at the second and third levels were essentially the same without water closet operation, $1 . e .$, the long loop was at a constant pressure. The pressure at the first level was at or somewhat above atmospheric pressure in the soil stack. With water closet loads differences in pressure in the long loop appeared from the second to third level. However, when water closets were functioning, the difference in pressures between the second and third

* Instrumentation and DAS records for vent pressure were based upon mm Hg units; conversion to $\mathrm{cm} \mathrm{H}_{2} \mathrm{O}$ multiply by 1.35 , and to in $\mathrm{H}_{2} \mathrm{O}$ multiply by 0.53 . 
levels were less than that in the conventional system. Extremes in pressures which exceeded $+2 \mathrm{~mm} \mathrm{Hg}$ were due to excessive loads on the system. Selected data polnts with greatest departures of pressure must be analyzed with care; e.g., in figure 15, point 1.1 represents the pressure in a branch drain with a water closet flushing upstream of the measurement station and the drain possibly filled thereby causing interference with the transducer.

The circulation loop strongly interconnected the vent stack with the soll stack between the third level to the second level resulting in very similar pressures. In all the tabulations those effects can be noted. When the long loop is carrying water closet discharge loads (In its role as a soll stack) the pressures tend to be similar to variations found in a conventional soll stack system, see figure 15. Strong pressure reductions at the upper level were due to the inlet overflow weir arrangement. This is in agreement with the results presented by Wyly and Eaton [6]; 1.e., in the soll stack inlet development length region very low pressures occur until terminal velocity conditions are achieved. The data from tests with discharging water closets did not display the stack pressures disturbances anticipated from other reports $[6,11]$. The high stack flow rates from the upper tanks may have dominated over the flow disturbances at the stack/horizontal drain fitting where mixing of the two flows occurred. However, the peak flow rates from the several water closets do tend to equal or exceed those in the soll stack. The same size piping, used in the test configurations, may have been another contributing cause. A circulation loop of the same pipe size as the main drain stack may protect the soll stack from undue pressure variations. With the same (large) plpe sizes, the pressure gradient will tend to be eliminated since friction losses associated with the air flows are exceedingly small and, therefore, the similarity of pressures between levels 2 and 3 . The diversion of waste loads by the long loop introduced the load into the soll stack in a region of higher (closer to atmospheric) pressure. The figures 12-15 show the mean values of the pressures.

In the tests the conventional system generally had a greater length of the lower portion of the soll stack at positive pressures which was probably due to backup of water at the (exit) elbow. The discussion of the cause of the loss of siphonic action in lower level water closets (in section 4.7) and even back flow from those fixtures indicates that soll stack water was backed up.

In figure 16, test results for the mean values from the pressure data (obtained within each group comprised of the 30 pressure readings in ten consecutive intervals of three seconds each) are shown. Two samples were selected to show the effects of all and no water closets in operation with the waste stack load at $4.38 \mathrm{l} / \mathrm{s}(80 \mathrm{gpm})$. Note that operation of elther system with valves closed, to represent single soll stack operation, generally resulted in trap seal fallures and system pressures which exceeded $\pm 2 \mathrm{~mm} \mathrm{Hg}$.

For the valve open position tests, with the vent stack valves open, and with all the water closets active the first ten seconds were run without flushing the water closets. Then, following the inftiation of the flush, a peak flow rate from the water closet was attained in up to another five seconds (for a total test time of 15 seconds). For the middle period (for 15 seconds elasped time) there were significant changes in the slope of the data points of the 
pressure measured in the branches on the three levels. During the last 10 seconds of the 30 second test period the pressures at the upper level were less affected by the interactions at the lower levels. By inspection of such data, it is evident that the value of the mean pressure over the entire period may not be a good indicator of conditions at the 1dle trap seals; the dynamic pressure variations can cause oscillations induced at the $1 d$ le trap seals. It therefore may become necessary to measure the trap seal transients to determine when the trap seal depletions occur.

\subsection{AIR FLOW RATES IN THE VENT NETWORK}

In addition to pressure measurements, hot wire anemometer flow measurements were made to attempt to determine the recirculation of air within the pipe vent network and the inflow-outflow volumetric rates. Those data for the air flow rates in the network were found to contain excessive errors at very low rates.

Hot wire anemometry was selected for measuring alr flow velocitles within the vent pipe system; such devices have insignificant effects on the flow and do not introduce additional frictional losses. The shortcoming of these instruments is that the velocity is measured at one location in the cross section of the pipe and an assumption must be made about the velocity profile so the total air flow rate across that pipe section can be calculated.

A serious constraint in measuring the air flow rates was the actual geometry of the vent network. The maximum free upstream and downstream distances from the hot wire could not be the recommended ten plpe dlameters because of the short straight plpe runs between junctions and bends in the system. A distance of ten diameters is generally sufficlent for attalning a reasonable degree of accuracy for high flow rates. In many cases the air flows in the vent network attained Reynolds numbers as $10 \mathrm{w}$ as 100. In addition, the flows in the vicinity of bends and junctions is comprised of mixing streams and secondary swirls. The hot wire must be placed a distance away from these locations to obtain the desired accuracy. Figure 17 indicates that expected accuracles with the hotwire instrument in the flow net. The calculated error is expresssed as a percentage of the total flow rate leaving the junction in relation to the total flow rate entering the junction. As noted, errors up to 50 percent may result for flow rates of $.95 \mathrm{l} / \mathrm{s}(2 \mathrm{cfm})$ and results of flow rates of a magnitude of $1 \mathrm{cfm}$ may be entirely invalid. Table 3 (sample of a computer output of a test run) lists the percentage error in the flow rates at designated junctions. Table 4 indicates that the deviation of the air flow rates among identical inputs is relatively small even for small flow rates. This shows that the reading and experimental condition at the hot wire is reproducible.

For tests in which the vent stack was kept open or partially open, relatively large flow rates occurred in the stack and 1 ts junctions. Therefore the results in these locations (higher Reynolds numbers) are reasonably accurate.

Figure 18 shows flow rates for several cases. The values for case $V$ were very accurate as can be seen by comparing the flows entering and leaving the junctions. The flow patterns in the vent net were not as anticipated. The pressure 
In the soll stack at the third level is negative; therefore large flows took place from the vent stack into the branch vent network feeding the soll stack. At the first level the situation is reversed. The pressures in the soll stack and drain were positive and the tendency was for the system to drive the excess alr towards the vent stack.

Figure 19 compares the alr flows and the associated branch static pressures measured during a test run at two stations in the network. The data are in agreement with anticipated values inasmuch as the flow rate variations and flow directions agree with the varlations in the pressures (1.e., the decrease in flow rate occurs with a decrease in pressure). Such relationships could only be verifled for high alr flow rates. For low alr flow rates, the errors in the measurement were relatively large, as discussed above, and the degree of correlation was uncertain.

\subsection{TRAP SEAL DEPLETION}

One of the most 1mportant measures of performance of the system was the trap seal loss at the simulated bathtubs. For the waste loads imposed in the test series with the vent valves open, no trap seal fallures were experienced in efther the circulation loop or conventional systems. The extreme conditions of operating the systems in nonvented conflgurations, 1.e., single soll stack, resulted in elther excessive trap seal losses or fallures of the water closet. However, with vent valves partially open or fully open (as the vent system is Intended to function) smaller trap seal losses resulted for the circulation loop compared with the conventional drain vent system.

For the tests with only water closets discharged and no soll stack load, there were no trap seal fallures for the circulation loop system with vent valves open or closed. Under the same test conditions for the conventional system fallures with the vent valves closed occurred. Simllarly, with vent valves closed and soll stack load at $2.19 \mathrm{l} / \mathrm{s}(40 \mathrm{gpm})$ and with selected water closets discharged the conventional system had trap seal fallures whereas the clrculation loop did not. With vent valves open, water closets discharged and over a range of soll stack loads, no fallure occurred but the c1rculation loop generally had smaller trap seal losses than the conventional system and with only soll stack loads both systems had simflar trap seal depletions.

F1gures 20 and 21 display the trap seal losses as a function of the water flow rate from the soll stack supply tank without any active flxtures and the vent valves closed. Trap 1 was situated on the third level, traps 2 and 3 on the second level, and traps 4 and 5 on the first level. The criterion for fallure was a trap depletion in excess of $2.5 \mathrm{~cm}(1 \mathrm{lnch})$. The depletion of the trap seal in the first level was higher for the clrculation loop system; however, both systems met the criterion and did not fall. Traps 1, 2, and 3 attalned trap seal depletions values which are permissible by codes up to flow rates close to $3.28 \mathrm{l} / \mathrm{s}(60 \mathrm{gpm})$. The trap seal losses in the conventional system turned downward with higher stack loads due to the 1ncreased positive pressure in the lower sectlons of the stack whlch propagated upward; the suction pressures at levels 2 and 3 were reduced as shown by the decrease in trap seal loss. The trap seal losses in traps 1, 2, and 3 are larger than in traps 4 
and 5 since they experienced negative pressure which removed the water from the trap. Traps 4 and 5 experience positive pressure for which losses of the traps occurred primarily as a result of the oscillation of the water columns in the traps when the load was removed. For the circulation loop configuration traps 2 and 3 were subject to the low pressures induced by the overflow weir inlet at higher soil stack flow rates. The second level traps were subjected to those reduced pressures due to the large connecting loop tie-in near the top of the soll stack.

Figure 22 illustrates the trap seal depletions of traps 1,3 , and 5 for the circulation loop and the conventional system for soil stack flow rates of 2.19 $\ell / \mathrm{s}$ and $4.38 \mathrm{l} / \mathrm{s}$ ( 40 and $80 \mathrm{gpm}$ ) with vent valves closed, and for various combinations of simultaneous operations of the water closets. The data did not indicate a strong interaction between the water closets, $1 . e$. , an increase in the water closet hydraulic loading was not always followed by an increase of the trap seal depletion for all cases tested. The circulation loop improved the performance of trap 5 but resulted in a higher depletion of trap 3 . Observing the data for the flow rate of $2.19 \mathrm{l} / \mathrm{s}$ (40 gpm) only, it is observed that the circulation loop did improve the system as a whole. No trap failures were observed at the $2.19 \mathrm{l} / \mathrm{s}(40 \mathrm{gpm})$ rate with the circulation loop while failures occurred in trap 1 and trap 5. The data indicate that the circulation loop had an increase in load carrying capability representative of expanding the number of load producing fixtures for a single stack system.

\subsection{TRAP SEAL DEPLETION AND PRESSURE EXCURSION}

Figures 23A, 23B, and 23C display the correlation between the trap seal depletions and the pressure excursions for the three levels in the network with vent valves closed. These data show that the variations in the behavior of the traps were consistent with the (mean) pressure excursions in the system. It is noted tht for traps $I$ and 2 the trap seal depletion was increased for the conventional system up to $3.45 \mathrm{l} / \mathrm{s}(65 \mathrm{gpm})$ soil stack flows after which a sharp decrease took place. Correspondingly, increasing negative pressures occurred with flow up to $3.45 \mathrm{l} / \mathrm{s}(65 \mathrm{gpm})$ after which a sharp decrease in negative pressure took place. The correlation between the trap seal depletions and pressure excursions is quite consistent. The trap depth fallures for the conventional and circulation loop (traps 1 and 2 on figures 23B and 23C) are consistent with the occurrence of strongly reduced pressures, measured in the branches.

\subsection{EFFECT OF VARIATIONS IN THE VENT STACK AIR FLOW ON THE TRAP SEAL}

For all the tests conducted, the values for the trap seal depletion were very small when the vent stack was open. This was verified for the most severe loading conditions of $4.38 \mathrm{l} / \mathrm{s}(80 \mathrm{gpm})$ soil stack water flow and all the water closets in the system operating. In order to test the effectiveness of the vent stack, a series of tests were performed where the inlet valves to the vent stack were partially closed in a series of steps and the corresponding trap seal depletions were recorded. 
The trap seal depletion as a function of the vent stack alr flow rate the conventional system with a soll stack water flow rate of $3.45 \mathrm{l} / \mathrm{s}$ (65 gpm) 1s shown in figure 24. It is noted that the vent stack capacity was oversized as Indicated by the leveling out of the small trap losses as the vent valves were opened. It appears that a capacity reduction of one-third (in terms of vent stack alr flow contribution to the total alr demands) could have been made and still the integrity of the trap seal would have been retained. The vent valve closure conditions simulated a reduced size venting system. Veriflcation of this could be done by running tests with a system of a reduced size plping having the same losses introduced by the valve closure. The experiments performed indicate that although a vent stack and branch vents are required, they may be appreclably reduced in size and still maintain the integrity of the trap seal. This concept has been demonstrated by other investigators but to date such results have not resulted in any changes in the plumbing codes.

\subsection{PERFORMANCE OF THE WATER CLOSETS}

Another area of concern in this study was the possibllity of poor performance of the water closets elther due to (1) the negative pressures which have the undesirable effect of first depleting the trap (even without a fallure mode) resulting in reduced water level in the bowl and subsequent inadequate siphonic action in the water closet in the next flush cycle, or (11) the positive pressures that reduce the total effective hydraulic head in the water closet which may affect (or eliminate) the siphonic action of the water closet.

A detalled study of water closet performance was made when the conventional system was tested, with the results described in table 5. Table 5 indicates that the performance of the water closet was very much affected by the pressure excursions in the DWV system. In the absence of stack venting and with high soll stack flows, no slphonic action occurred for the water closets in the first level, and at the extreme loads complete suction of the water closet traps took place in the upper levels. When the vent stack valves were open to one-half capacity the undesirable feature of loss of siphon was nearly ellminated except at the highest soll stack flow of $4.38 \mathrm{l} / \mathrm{s}(80 \mathrm{gpm})$; (the trap seal depletion values were still relatively high). For the clrculation loop system the assessment of the siphonic action was based upon observations of the water in the bowl after inftiation of the flush; similar degradations (as with the conventlonal system) were not observed. However, with the vent valves open and the highest soll stack flow the branch drain pressures on the first level, as indicated in figures 12 and 15 (with $\mathrm{J}=1$ ), were reduced when compared with the conventional system. Such reductions in back-pressure (on the water closet) imply that the circulation loop venting can malntaln water closet performance when the conventional vent system may become marginal. 


\section{CONCLUSIONS AND RECOMMENDATIONS}

Laboratory experiments were conducted on a drain-waste-vent system in a conventional configuration as well as modified to include two circulation loops. The drainage system included $75 \mathrm{~mm}$ ( 3 in) soil stack, loops and drains while the vent stack and vent branches were $50 \mathrm{~mm}$ ( $2 \mathrm{in}$ ) in diameter. The tests included various combinations of hydraulic loading patterns in the soil stack and with selected fixtures which were connected to the branch piping discharged to simulate usage conditions.

The premise underlying the test of the vent circulation loop was that such a modification to an existing drain-waste-vent (DWV) system would provide redistribution of air for atmospheric pressure relief to a limited (marginal) vent pipe network. The test results showed that: (a) the pressure distributions in the soil stack with the circulation loop modification had reduced pressure gradients when compared to the conventional DWV system; (b) additional fixture loads were possible with the circulation loop without causing trap seal failures; (c) the siphonic action of water closets at large soil stack loads and at positive pressures in lower levels of a building could be maintained and the closets perform satisfactorily with the circulation loop whereas failures occurred in the conventional system; and (d) total air demand through the soil stack and vent stack remained approximately the same for the conventional and modified circulation loop systems.

The ratio of the air intake of the vent stack to the soil stack ingestion ranged from 1:6 up to 1:3. Independent research at other building research stations has indicated the same results. These data show that a range of variations in vent air flows should be introduced into vent stack design methods; the assumption of a constant ratio is currently used as the basis for current plumbing code vent sizing methods. Time-dependent air flow distributions and pressures in the branches were measured and have not been previously reported in the literature. The pressure excursions with large fixture loads were shown to be large; the swing from suction to positive pressure levels within the 30 second test period were pronounced. Additional dynamic tests are required before correlations can be made between the time varying pressures, oscillations of the trap seals, and trap seal losses.

Tests conducted at the limiting condition with the vent stack fully closed, Eepresentative of single (soil) stack systems, resulted in satisfactory performance for the conventional and circulation loop system up to moderate water loads in the soil stack; fallures were experienced at large water loads. Experiments with the conventional system were conducted using reduced vent stack air flows by gradual closure of the vent valves. Such air flow restrictions are equivalent to reducing the size of the vent stack. The results indicated that the vent stack size could be reduced appreciably without causing fallure of the trap seals. These findings reinforce previous laboratory and field tests which showed that vent stacks are generally overdesigned and can be appreciably reduced and still satisfy the required performance of the systein.

The results of the present tests have indicated a need for additional tests and/or research for the effects of circulation loop modifications. The inlet 
to the upper (two-story height) clrculation loop where 1 t connects to the soll stack should be reduced to a smaller plpe dlameter; the water driven "pumped" ejection effect which caused strong suction in the third and second levels would probably then be reduced due to greater orffice losses. Simulation of soll stack water loads from upper levels of multi-story building should be improved by providing an annular inlet gulde; the Inlet water load from the upper tank would then be a controlled annular flow to replicate the annular downflow found in long soll stacks. A larger group of wastewater loading patterns should be used, particularly, those which result in low alr flows in controlled 1ncrements into the vent of the circulation loop system so that changes in marginal vent performance can be determined. Measurements of dynamlc characteristics of plumbing vent systems are required to develop understanding of the hydraulic interactions within DWV systems.

The authors greatly appreclate the development of computer programs and assistance with the Instrumentation and DAS by $\mathrm{Mr}$. Paul Kopetka and the extensive contributions of $\mathrm{Mr}$. Michael McCall in conducting the laboratory experiments. 
6. REFERENCES

[1] Rehabilitation Guidelines, 1980, No. 7, Plumbing DWV Guideline for Residential Rehabilitation, U.S. Department of Housing and Urban Development, Washington, D.C.

[2] Uniform Plumbing Code, International Assoclation of Plumbing and Mechanical officials, Los Angeles, Callfornia.

[3] National Standard Plumbing Code, National Assoclation of Plumblng-HeatingCooling Contractors, Washington, D.C.

[4] The BOCA Basic Plumbing Code, Bullding Officials and Code Administrators International, Inc., Homewood, Illinois.

[5] Standard Plumbing Code, Southern Bullding Code Congress International, Inc., Birmingham, Alabama.

[6] Wyly, R.S., and Eaton, H.N., Capac1ties of Stacks in Santtary Dra1nage Systems for Buildings, National Bureau of Standards, Monograph 31, 1961.

[7] Lillywhite, M.S.T., and Wise, A.F.E., Towards a General Method for the Design of Drainage Systems in Large Bulldings, Bullding Research Station Current Paper: C027/69, August 1969.

[8] Chakrabart1, S.P., Studies on the Development of Economical Drainage Systems for Multi-Storyed Buildings, Ph.D., Dissertation, University of Roorkee, India, October 1980.

[9] Kopetka, P., and Galowin, L., Reduced Size Vents for Veterans Administration Hosiptals, National Bureau of Standards Letter Report to V.A., December 1980 .

[10] Pink, B.J., The Effect of Stack Length on the Air Flow in Drainage Stacks, Building Research Establishment Current Paper 38/73.

[11] Wise, A.F.E., Water, Sanitary and Waste Services for Buildings, B.T. Batsford Limited, London, 1979.

[12] Jeppson, R.W., Anaysis of Flow in Pipe Networks, Ann Arbor Science Publishers Inc., 3rd Printing, 1979.

[13] Watters, G.Z., Modern Analysis and Control of Unsteady Flow in Pipelines, Ann Arbor Science Publishers Inc., 1979. 
Table 1. Size and Length of Vents*

\begin{tabular}{|c|c|c|c|c|c|c|c|c|c|c|}
\hline \multirow[b]{3}{*}{$\begin{array}{l}\text { S1ze of Soll } \\
\text { Waste Stack }\end{array}$} & \multirow[b]{3}{*}{$\begin{array}{c}\text { P1xtures } \\
\text { Un1ts } \\
\text { Connected }\end{array}$} & \multicolumn{9}{|c|}{ Diameter of Vent Required (Inches) } \\
\hline & & $1-1 / 4$ & $1-1 / 2$ & 2 & $2-1 / 2$ & 3 & 4 & 5 & 6 & 8 \\
\hline & & \multicolumn{9}{|c|}{ Maximum Length of Vent (feet) } \\
\hline Inches & & & & & & & & & & \\
\hline $1-1 / 2$ & 8 & 50 & 150 & & & & & & & \\
\hline $1-1 / 2$ & 10 & 30 & 100 & & & & & & & \\
\hline 2 & 12 & 30 & 75 & 200 & & & & & & \\
\hline 2 & 20 & 26 & 500 & 150 & & & & & & \\
\hline $2-1 / 2$ & 42 & & 30 & 100 & 300 & & & & & \\
\hline 3 & 10 & & 30 & 100 & 200 & 600 & & & & \\
\hline 3 & 30 & & & 60 & 100 & 500 & & & & \\
\hline 3 & 60 & & & 50 & 80 & 400 & & & & \\
\hline 4 & 100 & & & 35 & 100 & 260 & 1000 & & & \\
\hline 4 & 200 & & & 30 & 90 & 250 & 900 & & & \\
\hline 4 & 500 & & & 20 & 70 & 180 & 700 & & & \\
\hline 5 & 200 & & & & 35 & 80 & 350 & 1000 & & \\
\hline 5 & 500 & & & & 30 & 70 & 300 & 900 & & \\
\hline 5 & 1100 & & & & 20 & 50 & 200 & 700 & & \\
\hline 6 & 350 & & & & 25 & 50 & 200 & 400 & 1300 & \\
\hline 6 & 620 & & & & 15 & 30 & 125 & 300 & 1100 & \\
\hline 6 & 960 & & & & & 24 & 100 & 250 & 1000 & \\
\hline 6 & 1900 & & & & & 20 & 70 & 200 & 700 & \\
\hline 6 & 600 & & & & & & 50 & 150 & 500 & 1300 \\
\hline 8 & 1400 & & & & & & 40 & 100 & 400 & 1200 \\
\hline 8 & 2200 & & & & & & 30 & 80 & 350 & 1100 \\
\hline 8 & 3600 & & & & & & 25 & 60 & 250 & 800 \\
\hline 10 & 1000 & & & & & & & 75 & 125 & 1000 \\
\hline 10 & 2500 & & & & & & & 50 & 125 & 1000 \\
\hline 10 & 3800 & & & & & & & 30 & 80 & 350 \\
\hline 10 & 5600 & & & & & & & 25 & 60 & 250 \\
\hline
\end{tabular}

* From Reference 3. 


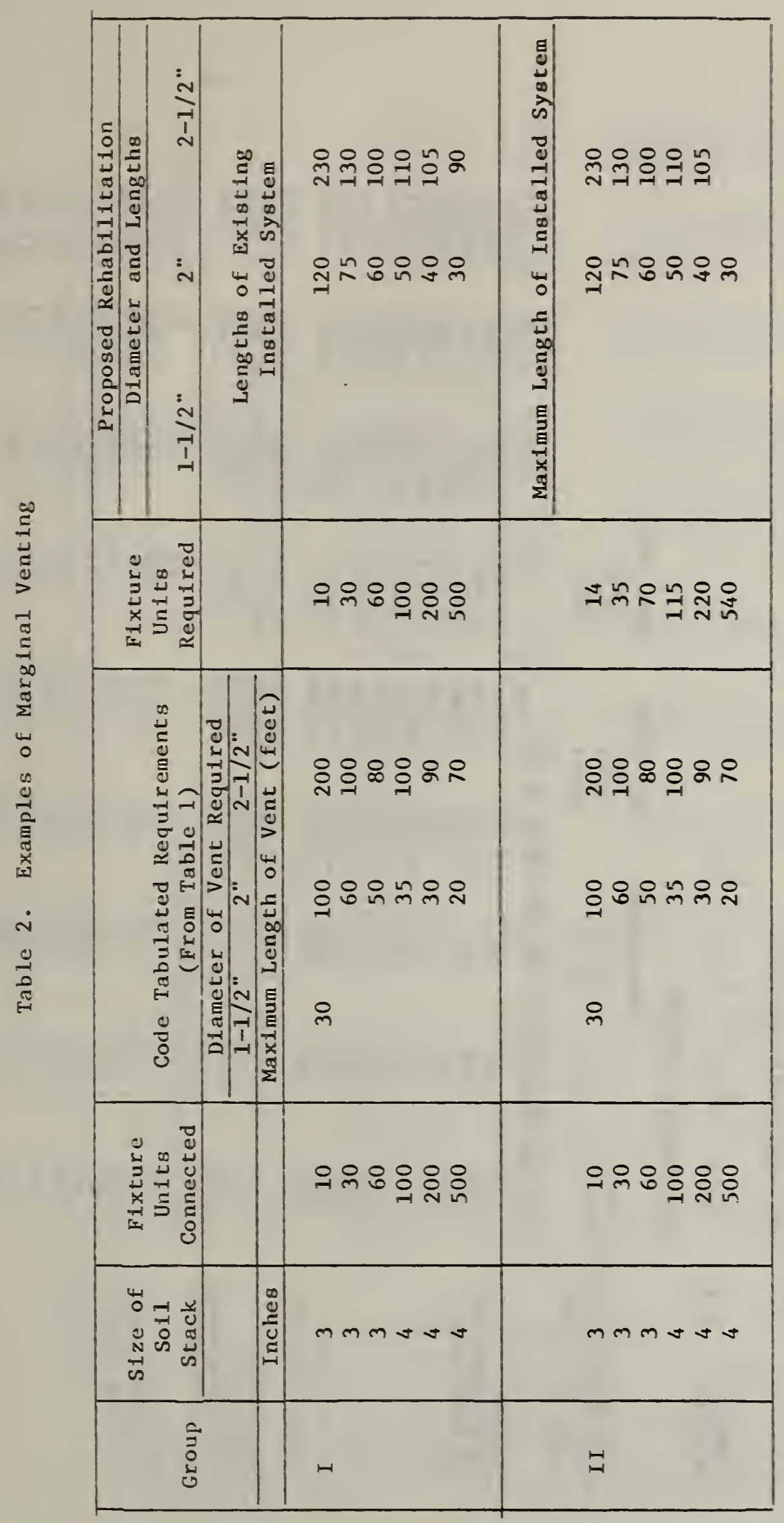




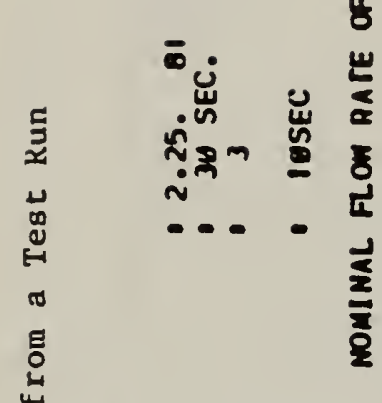

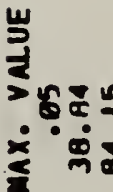

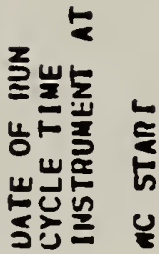

8

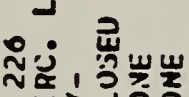

는겅옹융

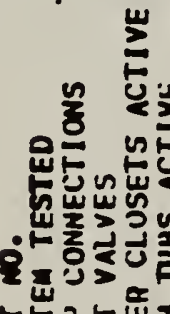

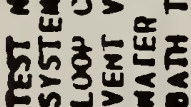

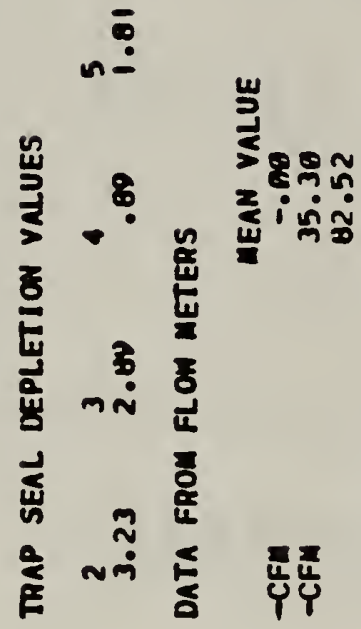

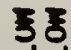

-

ำ

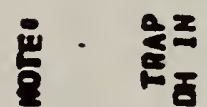

뜽휴
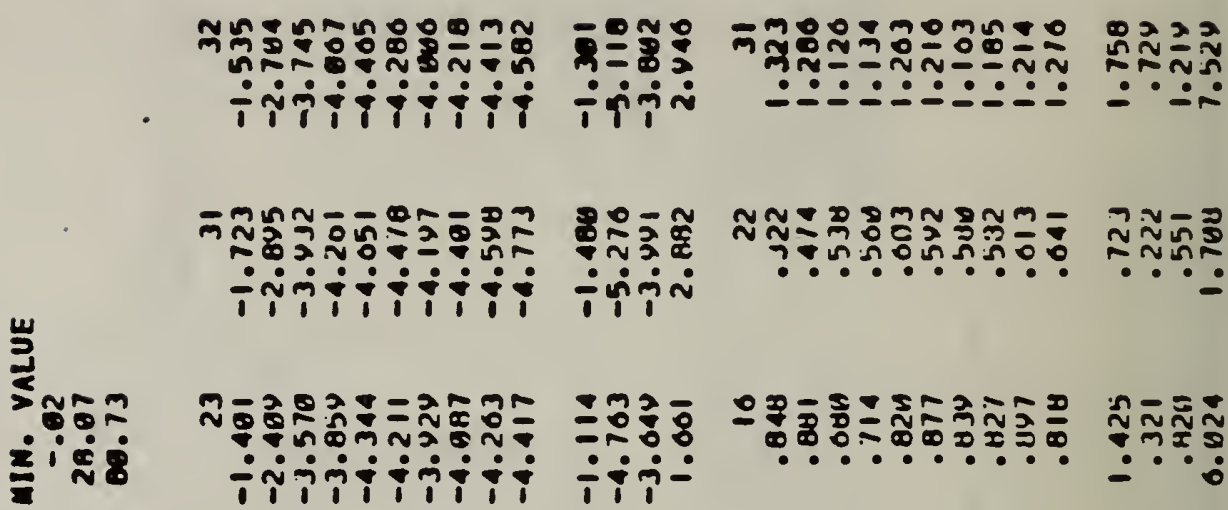

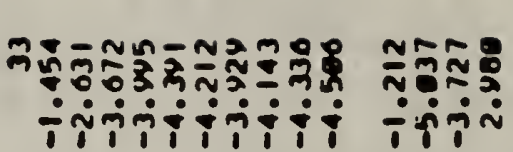

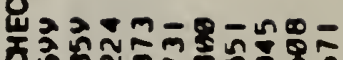

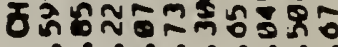

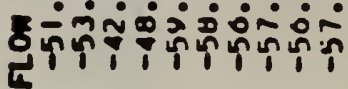

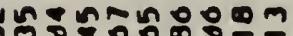

月ล응

भitititit imin

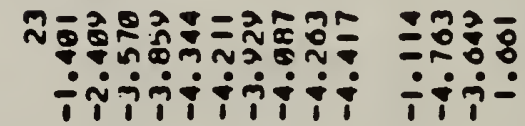

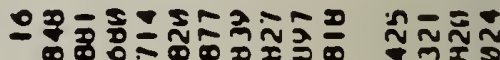
$\because \cdot \frac{1}{0}$

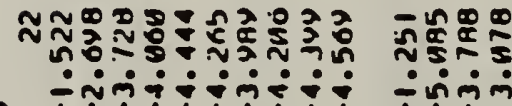

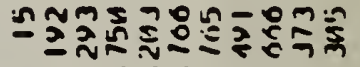

ク゚ฺ๊

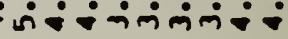

in்:

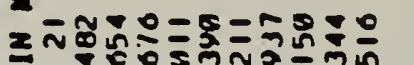

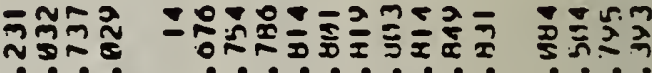

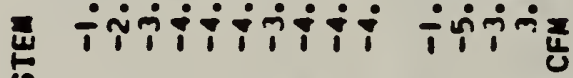

z

Sิ 舀 宸

密

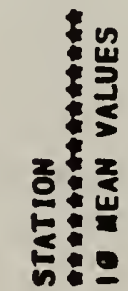

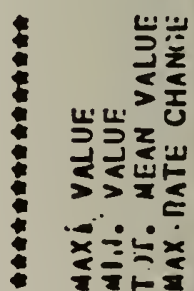




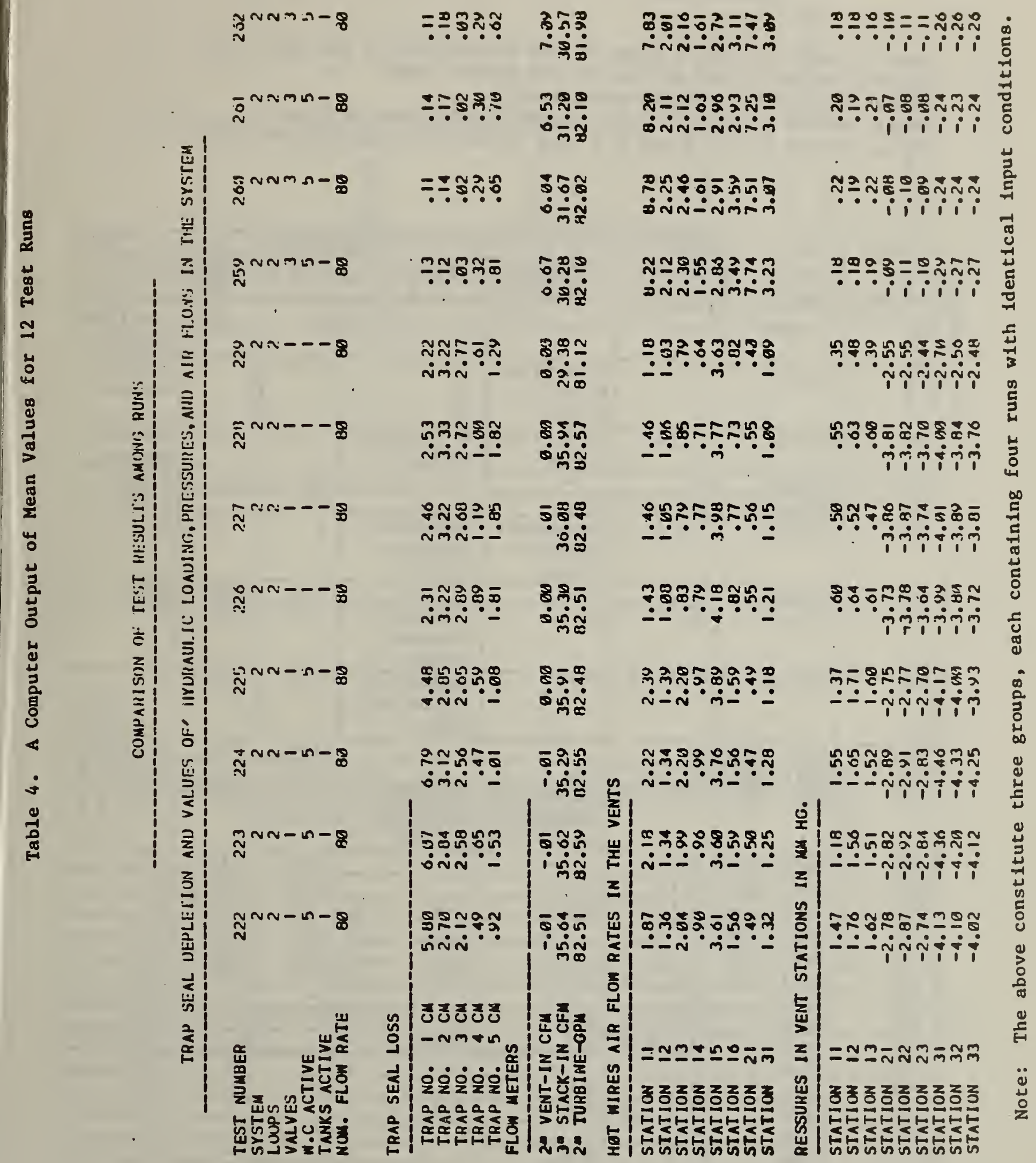


Table 5. Performance of the Water Closets in the Dralnage System (Convent1onal)

Water closets 1.1 and 1.2 are in the f1rst level of the test r18. Water closets 2.1 and 2.2 are in the second level.

Water closet 3.1 is in the third level.

Water closets 1.1 and 1.2 were tested for siphonic action.

Water closets $2.1,2.2$ and 2.3 were tested for trap seal depletion.

\begin{tabular}{|c|c|c|c|c|c|c|c|}
\hline \multirow{3}{*}{$\begin{array}{l}\text { Nominal } \\
\text { Water } \\
\text { Flow Rate }\end{array}$} & \multirow{3}{*}{$\begin{array}{l}\text { Vent } \\
\text { Valves } \\
\text { Position } \\
\end{array}$} & \multirow{3}{*}{$\begin{array}{l}\text { Water } \\
\text { Closets } \\
\text { Active } \\
\end{array}$} & \multicolumn{5}{|c|}{ Test Results } \\
\hline & & & \multicolumn{2}{|c|}{ Siphonie Action } & \multicolumn{3}{|c|}{ Trap Seal Depletion (') } \\
\hline & & & 1.1 & 1.2 & 2.1 & 2.2 & 3.1 \\
\hline 80 & Closed & 0 & - & - & 1 & $11 / 4$ & $\begin{array}{l}\text { Complete } \\
\text { Removal }\end{array}$ \\
\hline 80 & Closed & 1,1 & $\begin{array}{l}\text { Incomplete } \\
\text { Siphonic } \\
\text { Action }\end{array}$ & - & $11 / 2$ & $11 / 2$ & $\begin{array}{l}\text { Complete } \\
\text { Removal }\end{array}$ \\
\hline 80 & Closed & $1,11,2$ & $\begin{array}{l}\text { No Siphonid } \\
\text { Action }\end{array}$ & $\begin{array}{l}\text { No Siphonic } \\
\text { Action }\end{array}$ & $11 / 2$ & $11 / 2$ & $\begin{array}{l}\text { Complete } \\
\text { Removal }\end{array}$ \\
\hline 60 & Closed & 0 & - & - & $3 / 4$ & $3 / 4$ & $13 / 4$ \\
\hline 60 & Closed & 1,1 & $0 . K$. & - & $3 / 4$ & 1 & $13 / 4$ \\
\hline 60 & Closed & $1,11,2$ & $\begin{array}{l}\text { Incomplete } \\
\text { Siphonic } \\
\text { Action }\end{array}$ & $\begin{array}{l}\text { Incomplete } \\
\text { Siphonic } \\
\text { Action }\end{array}$ & 1 & $11 / 4$ & $13 / 4$ \\
\hline 40 & Closed & 0 & - & - & $1 / 2$ & $1 / 2$ & $3 / 4$ \\
\hline 40 & Closed & 1,1 & $0 / \mathrm{K}$ & $\begin{array}{l}\text { Incomplete } \\
\text { Siphonc } \\
\text { Action }\end{array}$ & $1 / 2$ & $1 / 2$ & 1 \\
\hline 40 & Closed & $1,1 \quad 1,2$ & $0 . \mathrm{K}$. & $\begin{array}{l}\text { Incomplete } \\
\text { Siphonic } \\
\text { Action }\end{array}$ & $1 / 2$ & $1 / 2$ & 1 \\
\hline 80 & Half open & 0 & $=$ & - & $1 / 4$ & $1 / 4$ & $11 / 4$ \\
\hline 80 & Half open & $1 ; 1$ & $0 . \mathrm{K}$. & - & $1 / 4$ & $1 / 4$ & $1 / 4$ \\
\hline 80 & Half Open & $1,1 \quad 1,2$ & $\begin{array}{l}\text { Incomplete } \\
\text { Siphonic } \\
\text { Action }\end{array}$ & $\begin{array}{l}\text { Incomplete } \\
\text { S1phonic } \\
\text { Action }\end{array}$ & $1 / 4$ & $1 / 4$ & $1 / 4$ \\
\hline 60 & Half open & 0 & - & - & $3 / 8$ & $3 / 8$ & $I^{\prime \prime}$ \\
\hline 60 & Half open & 1,1 & $0 . \mathrm{K}$. & - & $3 / 8$ & $3 / 8$ & $1^{\prime \prime}$ \\
\hline 60 & Half open & $1,11,2$ & $0 . \mathrm{K}$. & O.K. & $3 / 8$ & $3 / 8$ & $1^{11}$ \\
\hline 40 & Half open & 0 & $\overline{-}$ & - & $1 / 4$ & $1 / 4$ & $3 / 8$ \\
\hline 40 & Half open & 1.1 & $0 . \mathrm{K}$. & $=$ & $1 / 4$ & $1 / 4$ & $3 / 8$ \\
\hline 40 & Half open & $1,1 \quad 1,2$ & O.K. & $0 . K$ & $1 / 4$ & $1 / 4$ & $3 / 8$ \\
\hline 80 & Open & 0 & - & $=$ & - & - & $1 / 4$ \\
\hline 80 & Open & 1,1 & $0 . \mathrm{K}$ & $=$ & $=$ & - & $1 / 4$ \\
\hline 80 & Open & $1,11,2$ & $0 . \mathrm{K}$. & $0 . K$ & - & - & $1 / 4$ \\
\hline 60 & Open & 0 & - & $=$ & $=$ & - & $1 / 4$ \\
\hline 60 & Open & 1,1 & $0 . \mathrm{K}$. & $\overline{-}$ & - & - & $1 / 4$ \\
\hline 60 & Open & $1,11,2$ & $0 . \mathrm{K}$. & $0 . K$. & $=$ & $=$ & $1 / 4$ \\
\hline 40 & Open & 0 & - & - & - & - & - \\
\hline 40 & Open & 1,1 & 10.K. & - & - & - & - \\
\hline 40 & Open & $1,11,2$ & $0 . \mathrm{K}$. & $0 . \mathrm{K}$ & - & - & $=$ \\
\hline
\end{tabular}



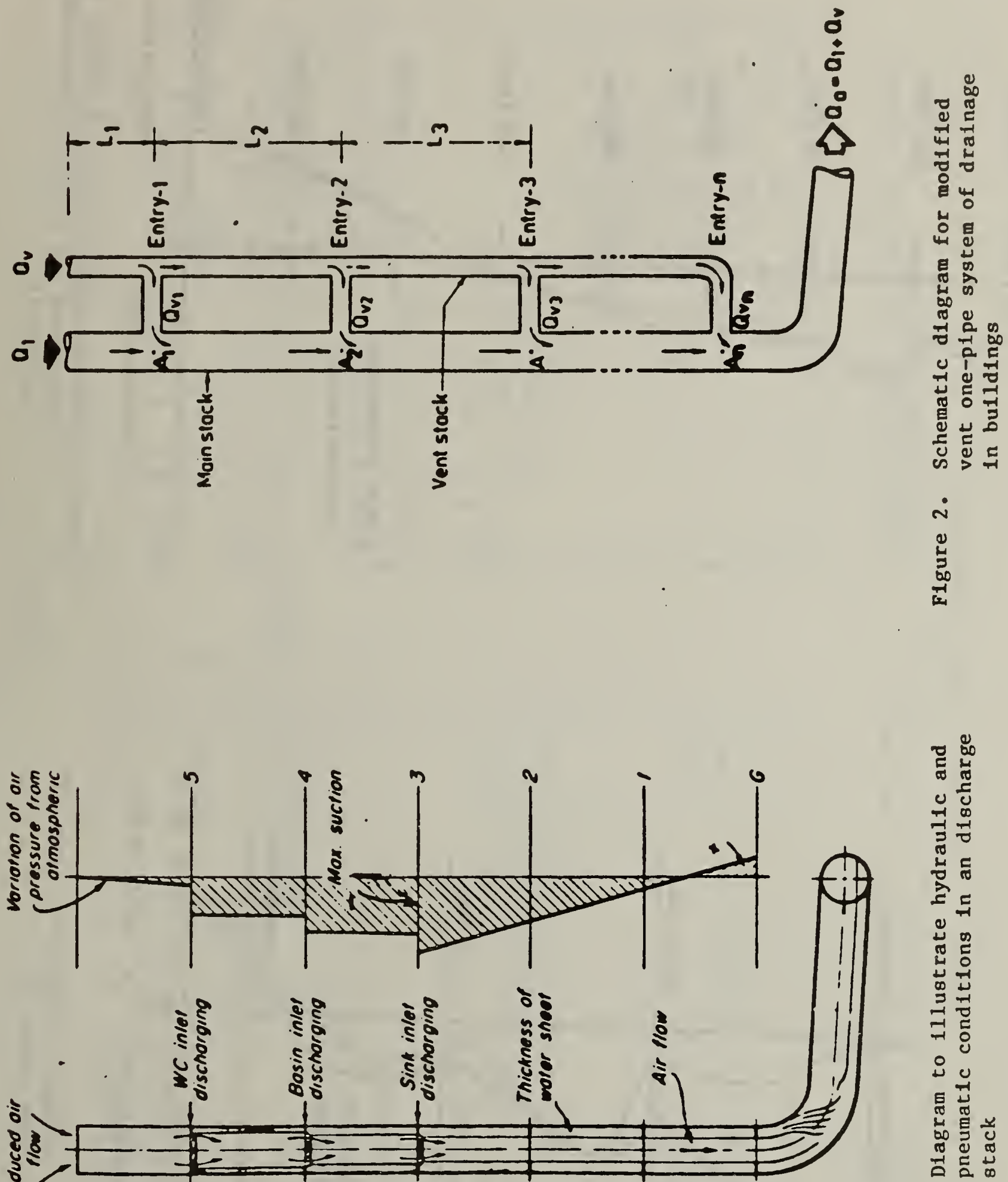

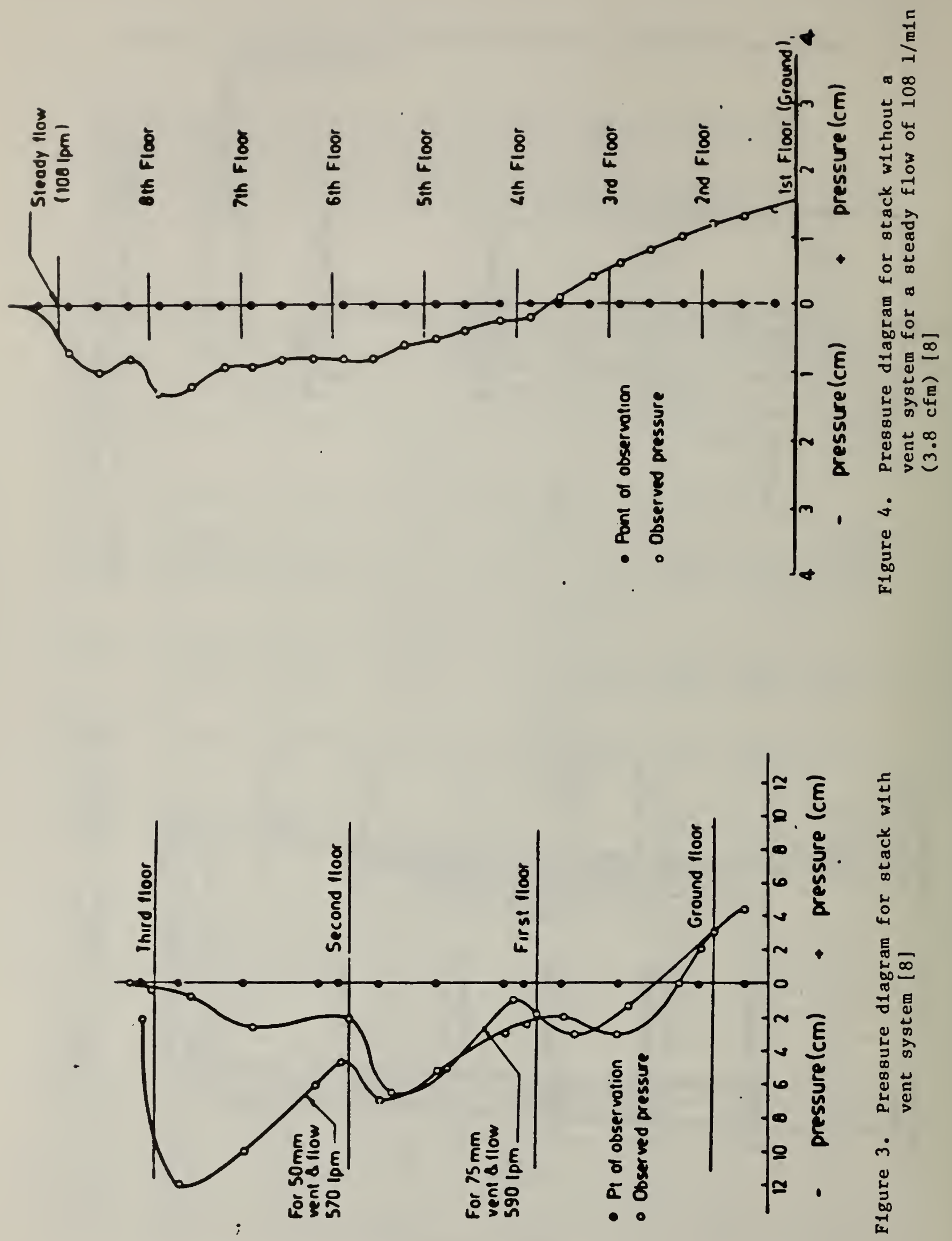

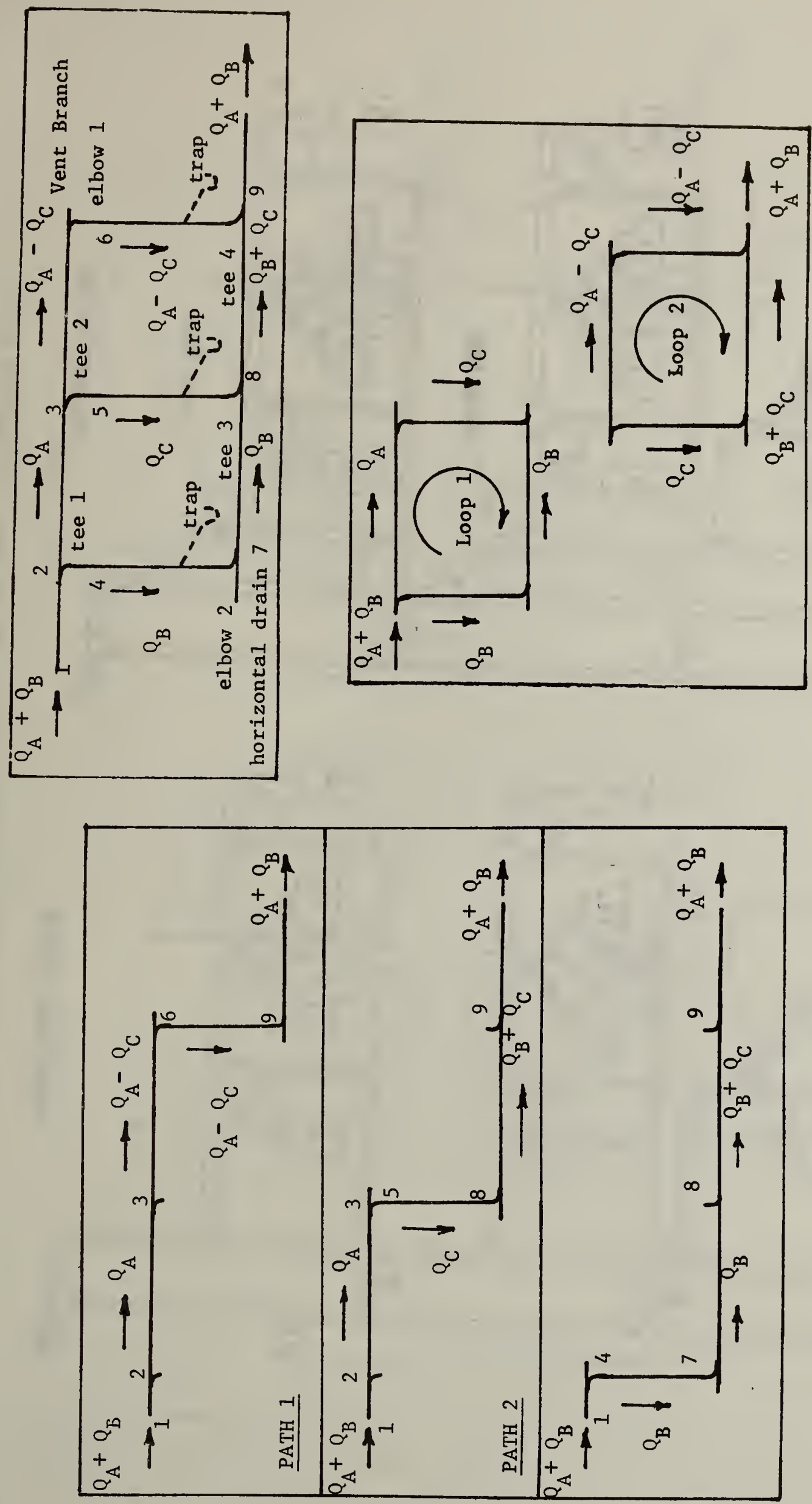

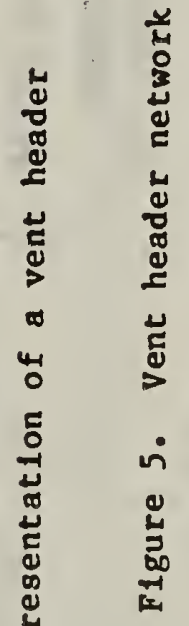




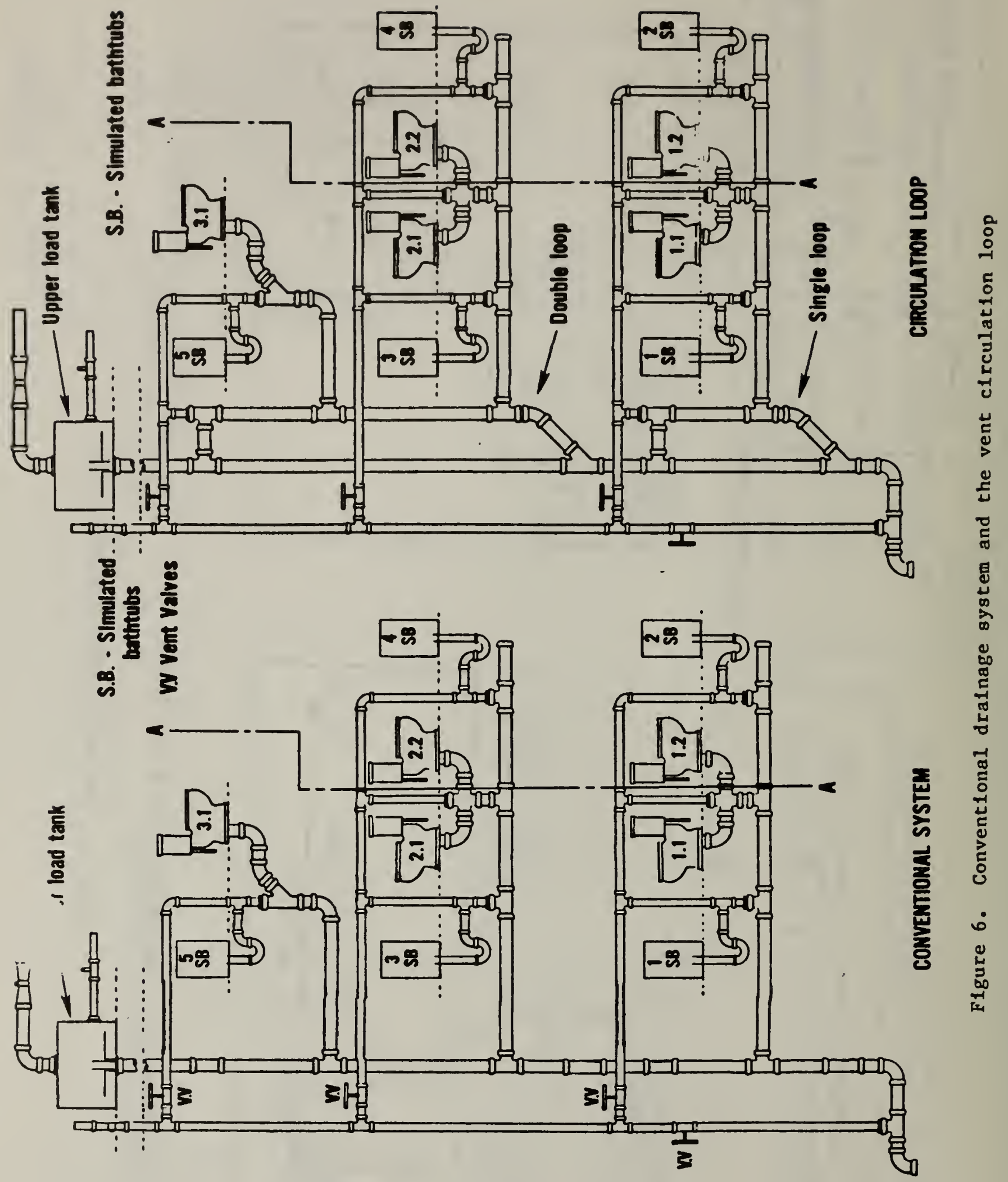




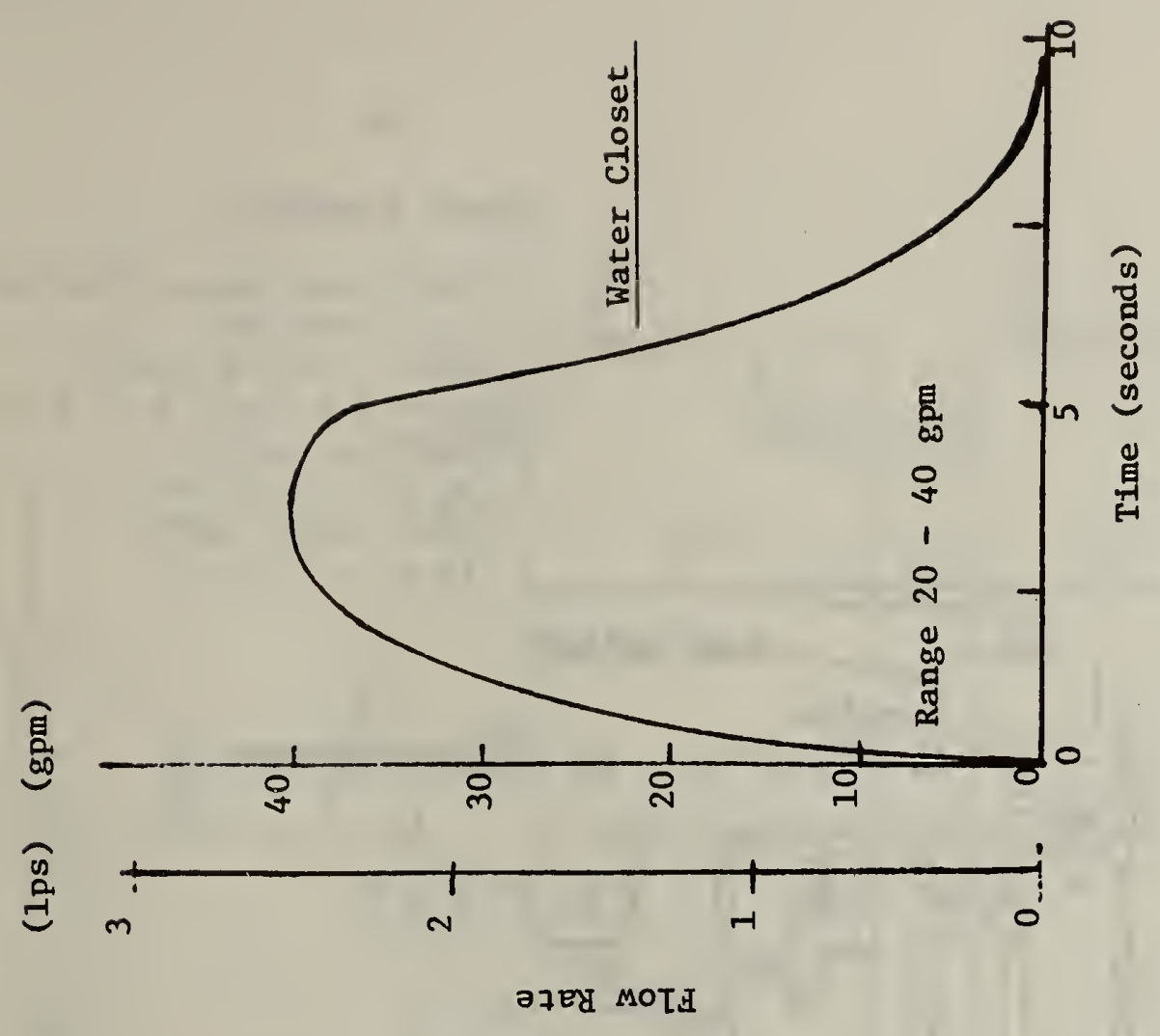

울

홈
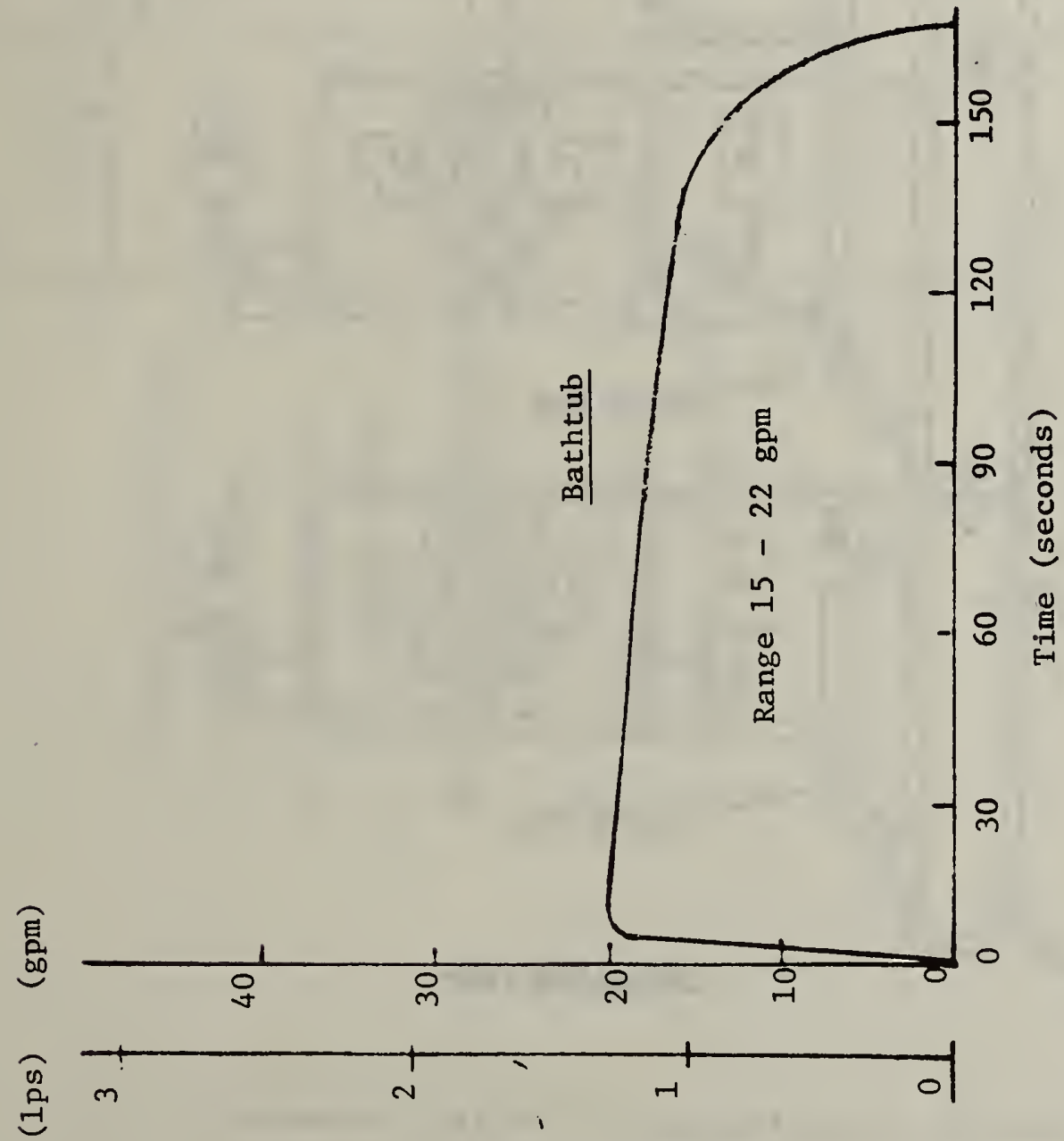

ә7EY MOTA 


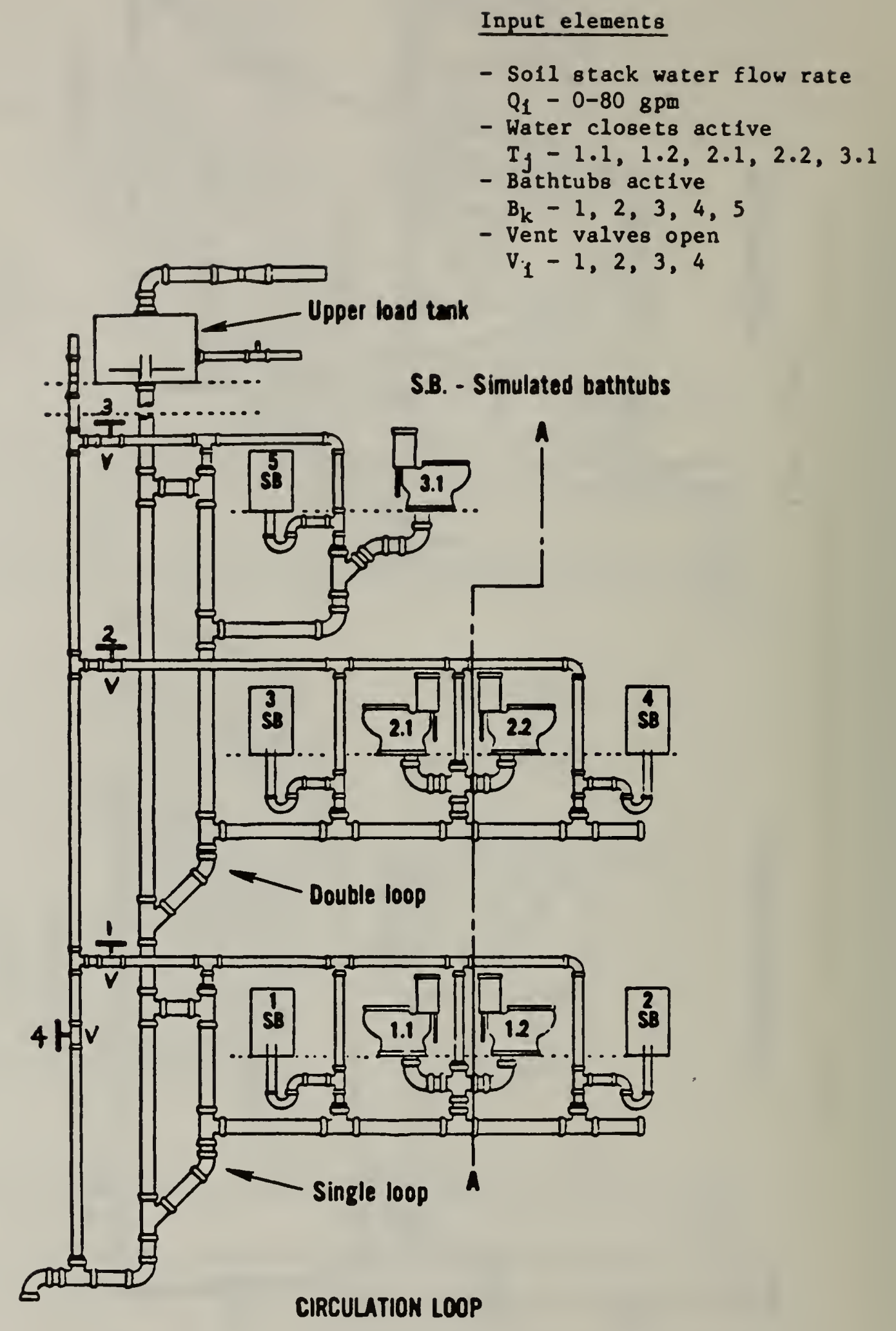

Figure 8. Identification of the input elements 


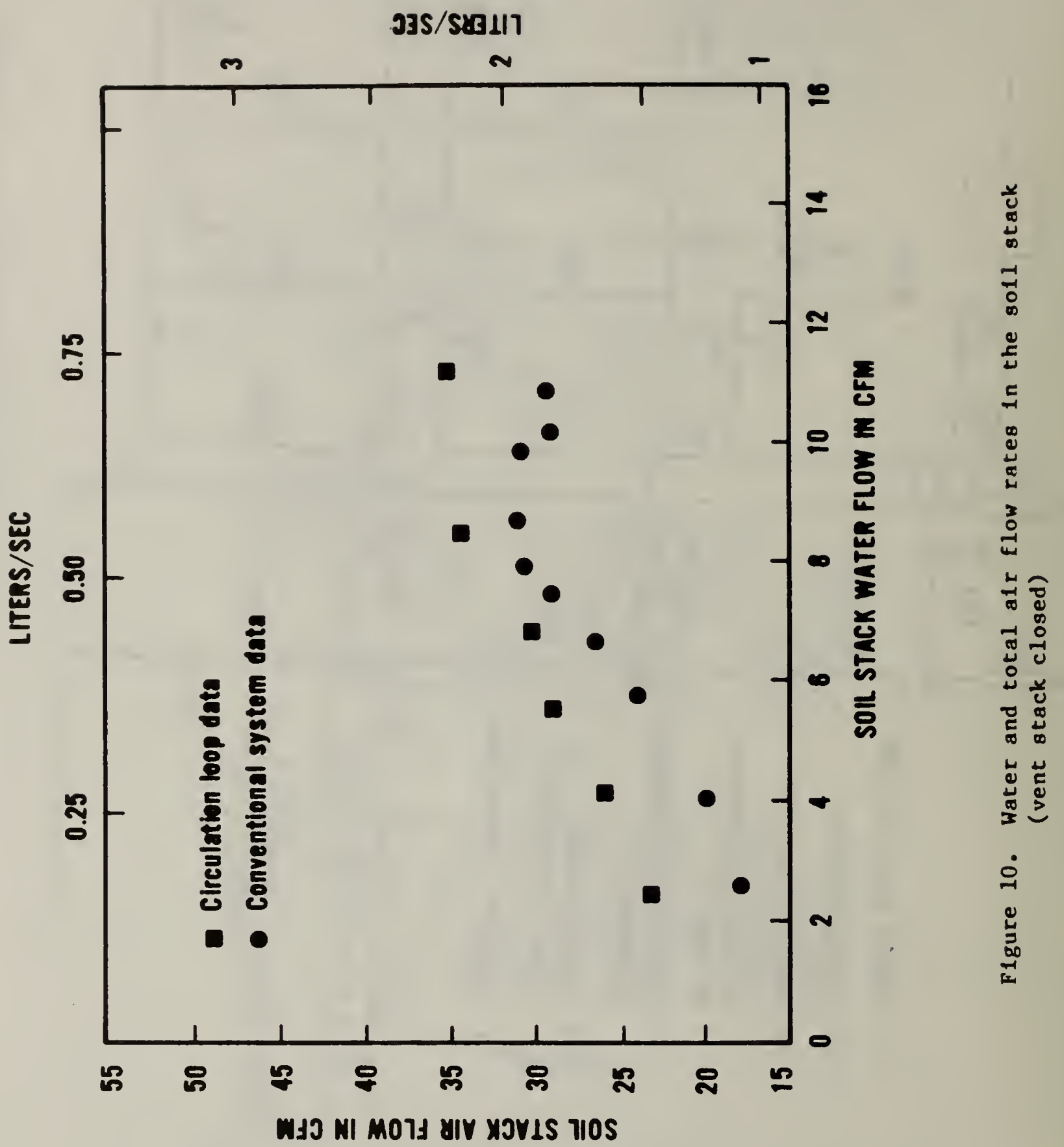




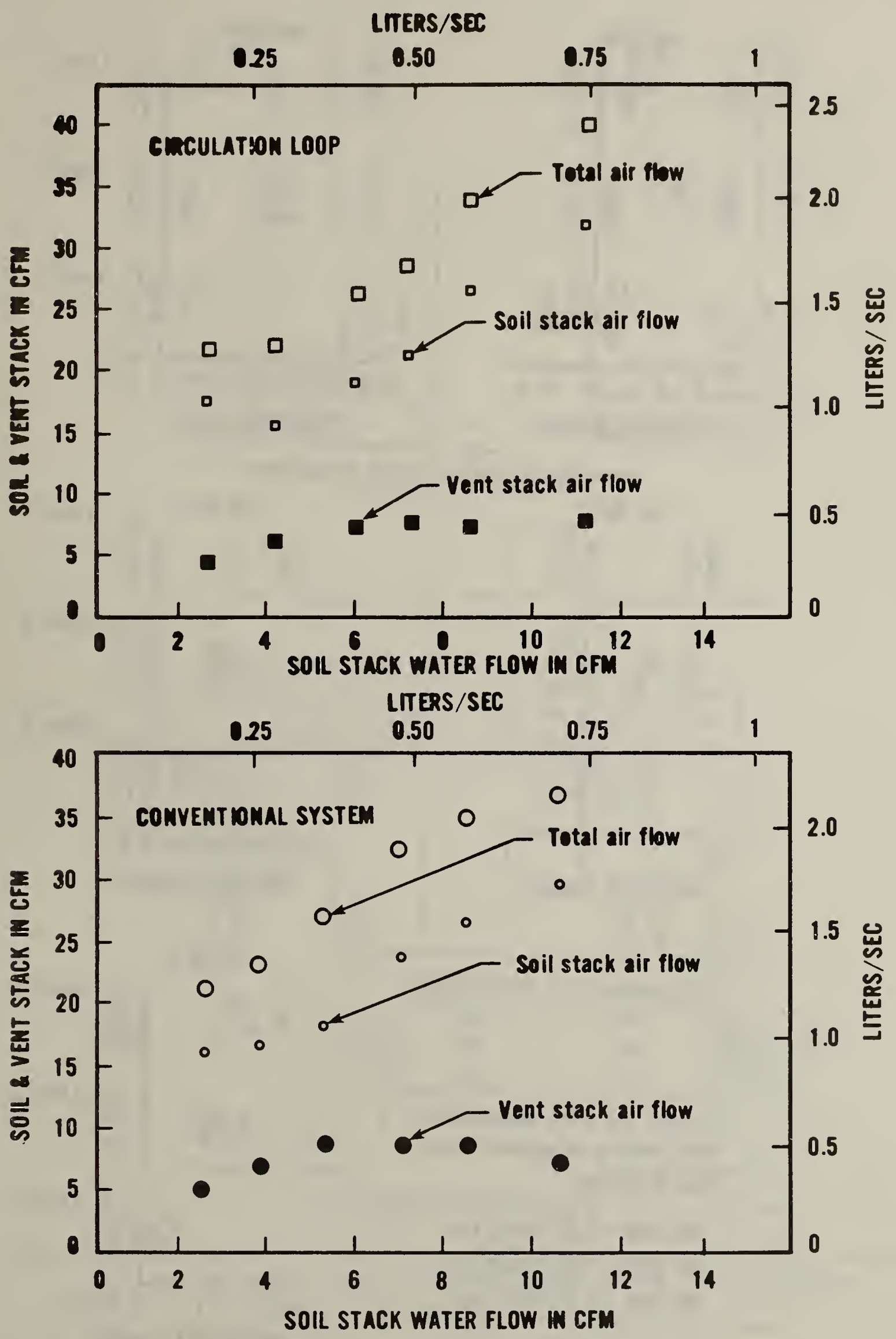

Figure 11. Soll stack water flow rates and the soll stack and vent stack air flow rates for the circulation loop and conventional system (various valye settings) 

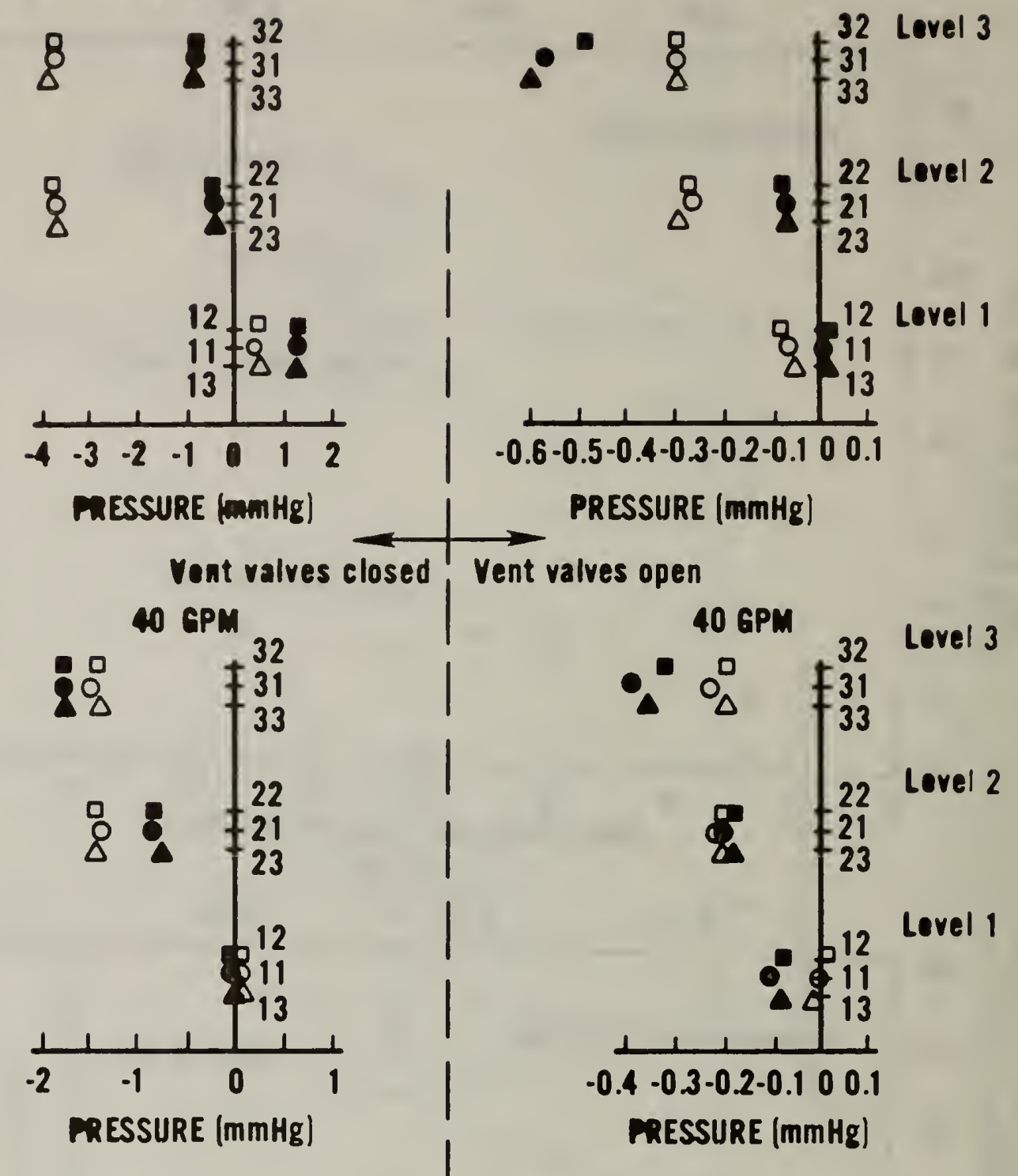

\begin{tabular}{|c|c|c|}
\hline & Circulation loop & Conventional \\
\hline$J 1$ & 0 & 0 \\
\hline $\mathbf{2}$ & $\square$ & $\mathbf{0}$ \\
\hline 13 & $\Delta$ & $\Delta$ \\
\hline & \multicolumn{2}{|c|}{$\begin{array}{l}J=3,2,1 \text { for third, second and } \\
\text { first lavel in laboratory (from } \\
\text { top to bottom) }\end{array}$} \\
\hline \multicolumn{3}{|c|}{$\begin{array}{l}0 \mathrm{GPM}=5.01 \text { liters } / \mathrm{sec} \\
40 \mathrm{GPM}=2.53 \text { liters } / \mathrm{sec} \\
20 \mathrm{GPM}=127 \text { liters } / \mathrm{sec}\end{array}$} \\
\hline
\end{tabular}

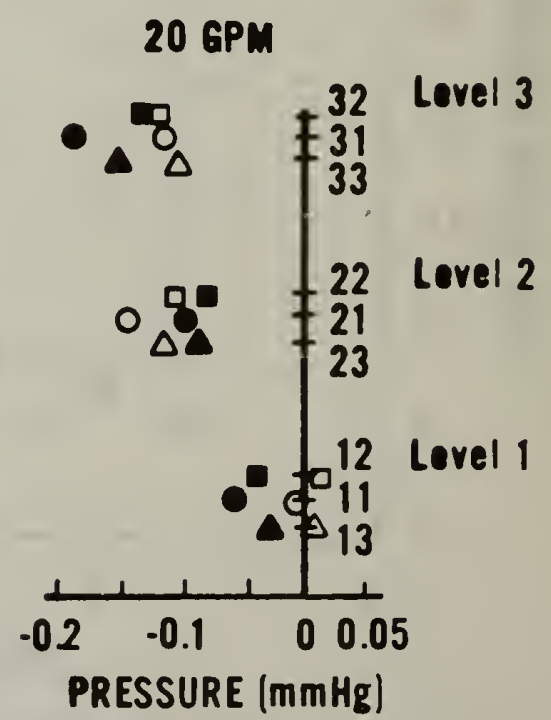

Figure 12. Pressures in branches with vent valves closed and open with 8011 stack lownflows and no water closets diccharged 

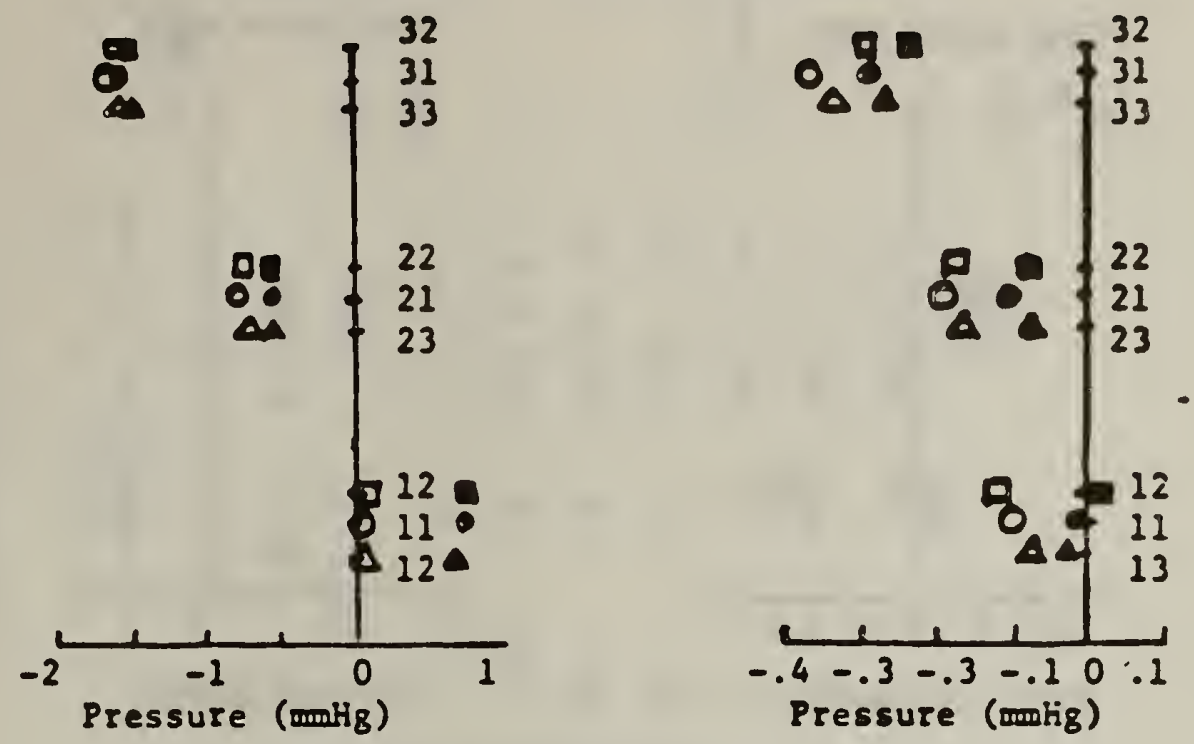

Conventional System

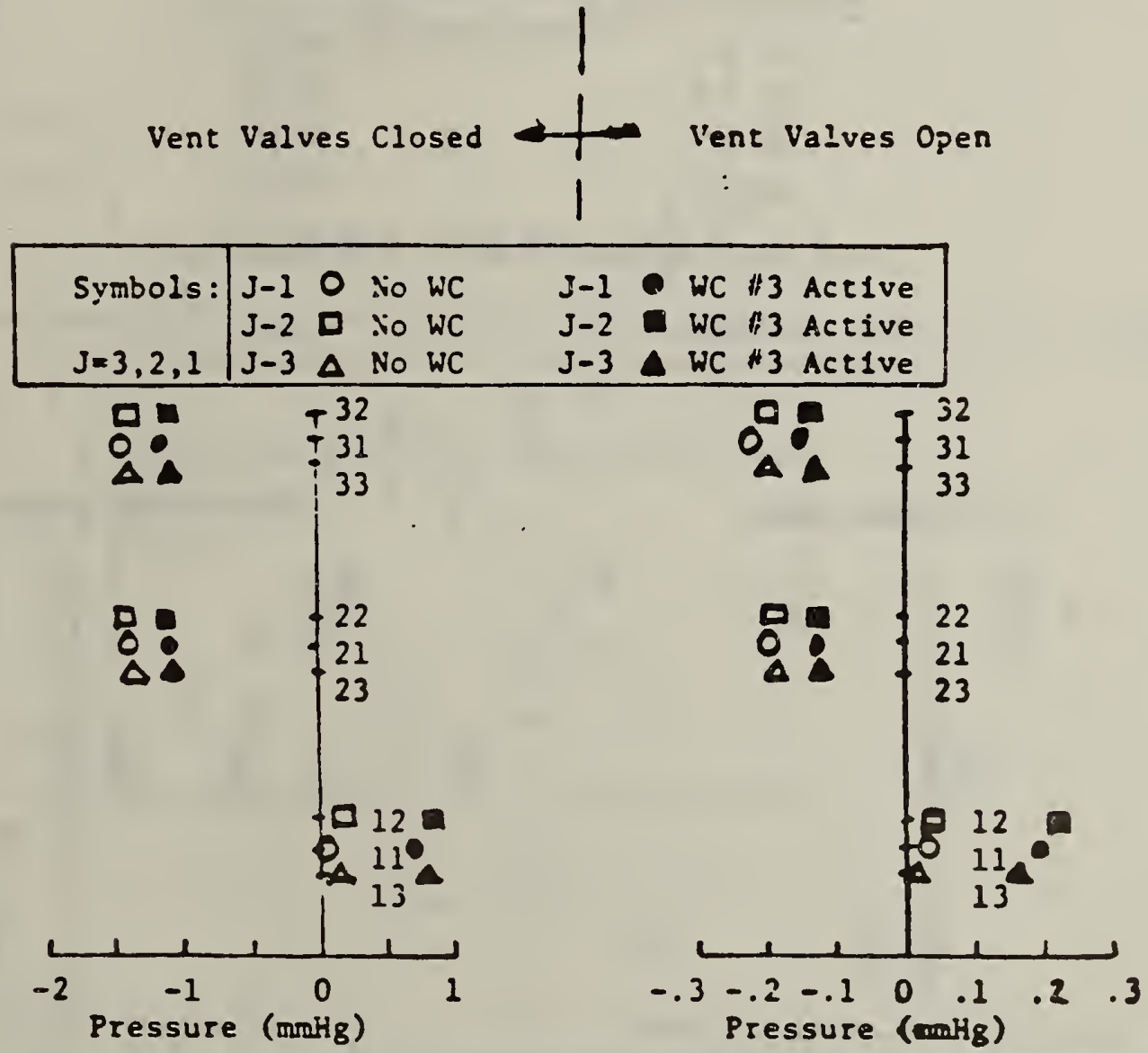

Circulation Loop System

Figure 13. Pressures in branches with $2.531 / \mathrm{s}$ (40 gpm) so1l stack downflow and one water closet discharge, vent valves closed and open 


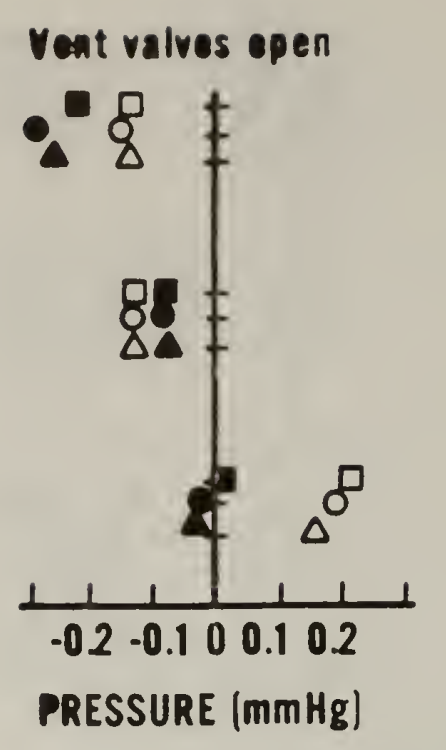

Circulation bop

O $\mathrm{J}-1$

口 J-2

$\Delta J-3$

$J=3,2,1$
Vent valves epen

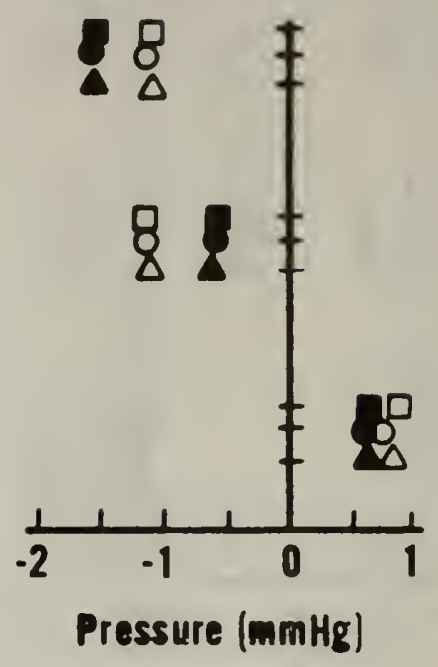

$\frac{\text { Conventional }}{J-1}$

- $\mathrm{J}-2$

$\Delta \mathrm{J}-3$

$J=3,2,1$

W.C. n. 3 active $(40 \mathrm{GPM}=2.53$ liters $/ \mathrm{sec})$

Figure 14. Branch pressures with $2.53 \mathrm{l} / \mathrm{s}$ (40 $\mathrm{gpm}$ ) and downflow one water closets discharged, vent valves closed and open
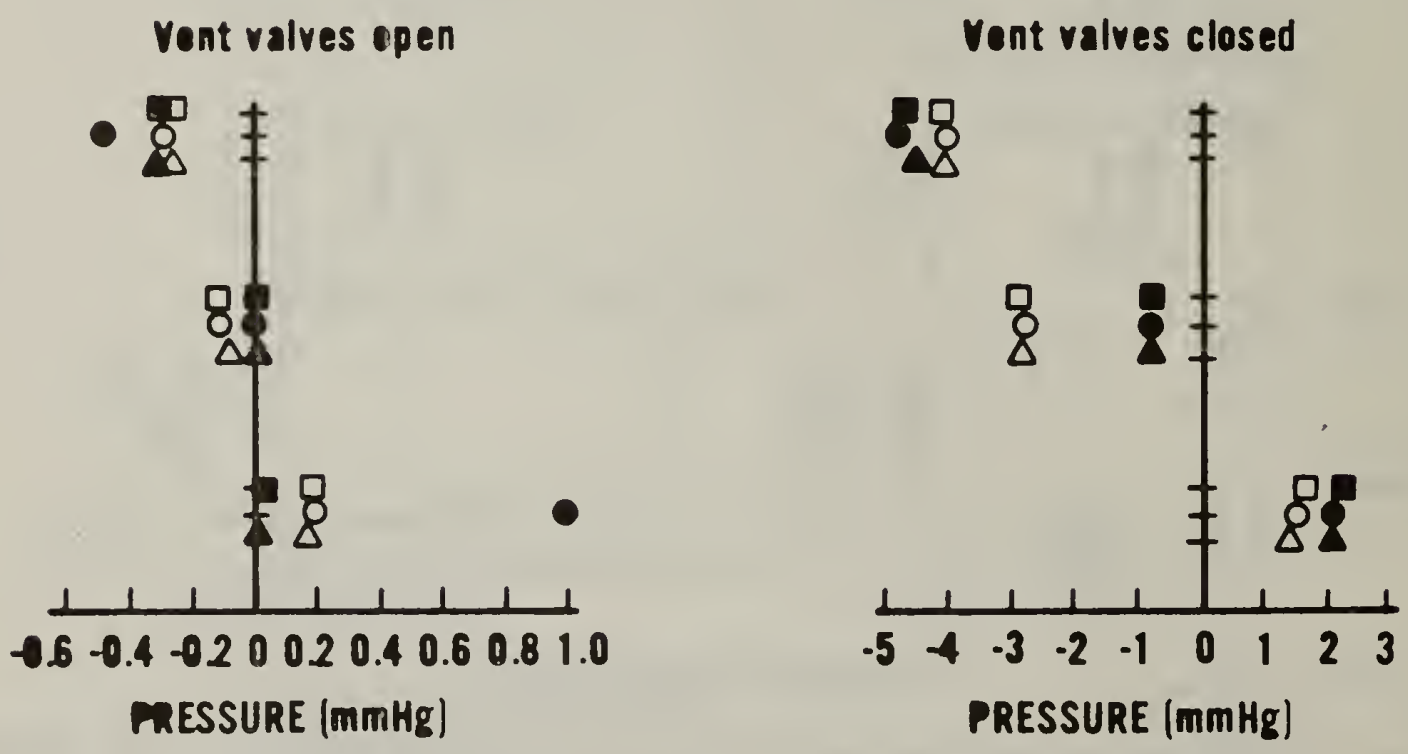

Symbols: Same as Figure 14

All W.C.'s active (80 6PM $=\mathbf{5 . 0 5}$ liters $/ \mathbf{s e c})$

Figure 15. Branch pressures with $5.051 / \mathrm{s}$ ( $80 \mathrm{gpm}$ ) and all water closets discharged, vent valves closed and open 

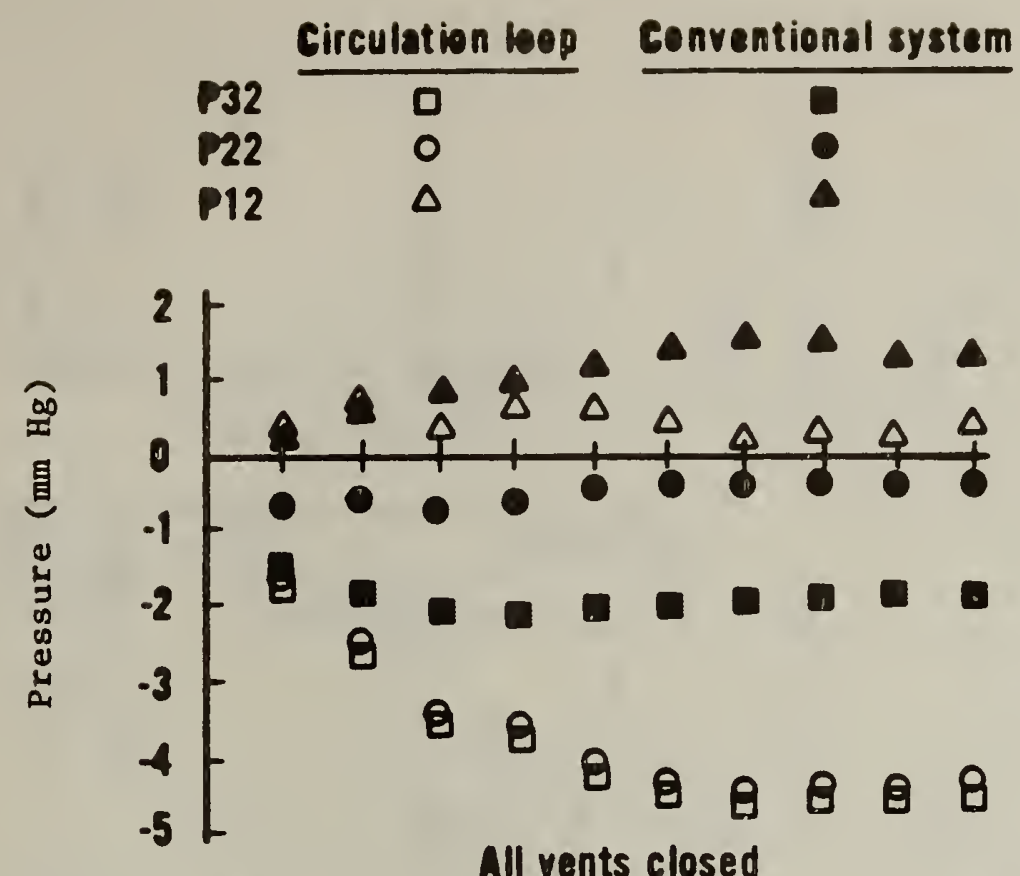

All vents closed

No WC's active

80 gpm downflow

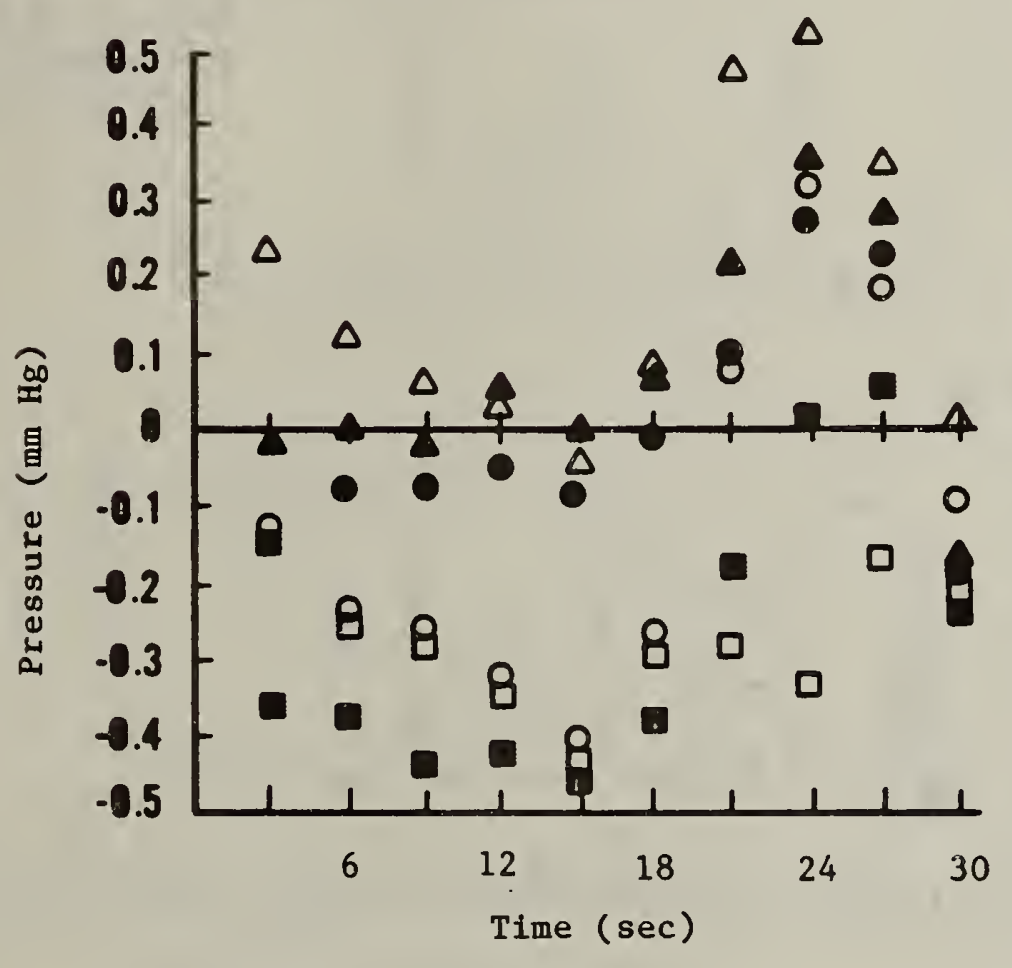

Symbols as above

All vents open

All W.C.'s active

$00 \mathrm{gpm}$ downflow $=\mathbf{5 . 0 5}$ liters $/ \mathrm{sec}$

Figure 16. Mean branch pressures as a function of time over three second intervals 
Tests at various functions

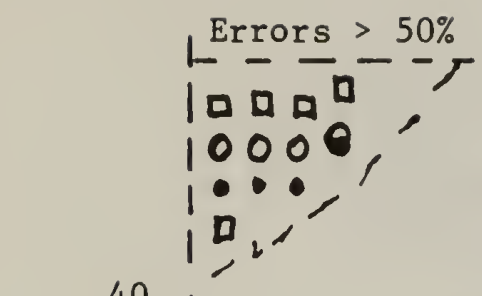



40

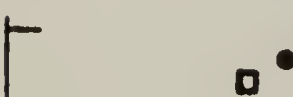

20
30

10

0

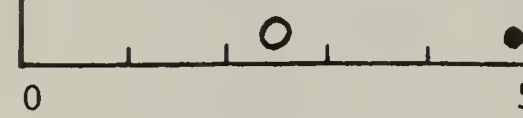

$L \approx 10$ pipe diameters

$Q_{1}-Q_{2}-Q_{3}=\Delta$

$\Delta \%=\frac{\Delta}{Q_{\mathrm{T}}} \quad .100$

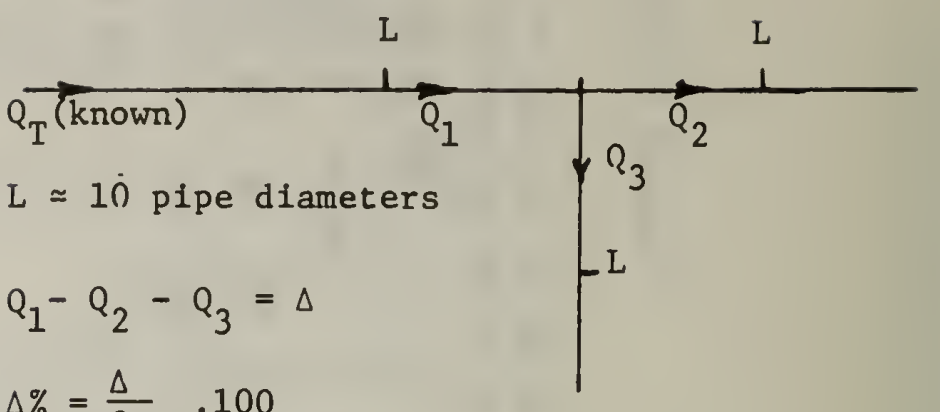

$R_{e}=$ Reynolds number based on pipe diameter

Symbols 0 - indicate individual test runs results at various junctions.

Air Flow Rate (cfm in 2" pipe)

Figure 17. Accuracy attained in measuring the air flow rates at junctions in the flow net by hot wire anemometry 

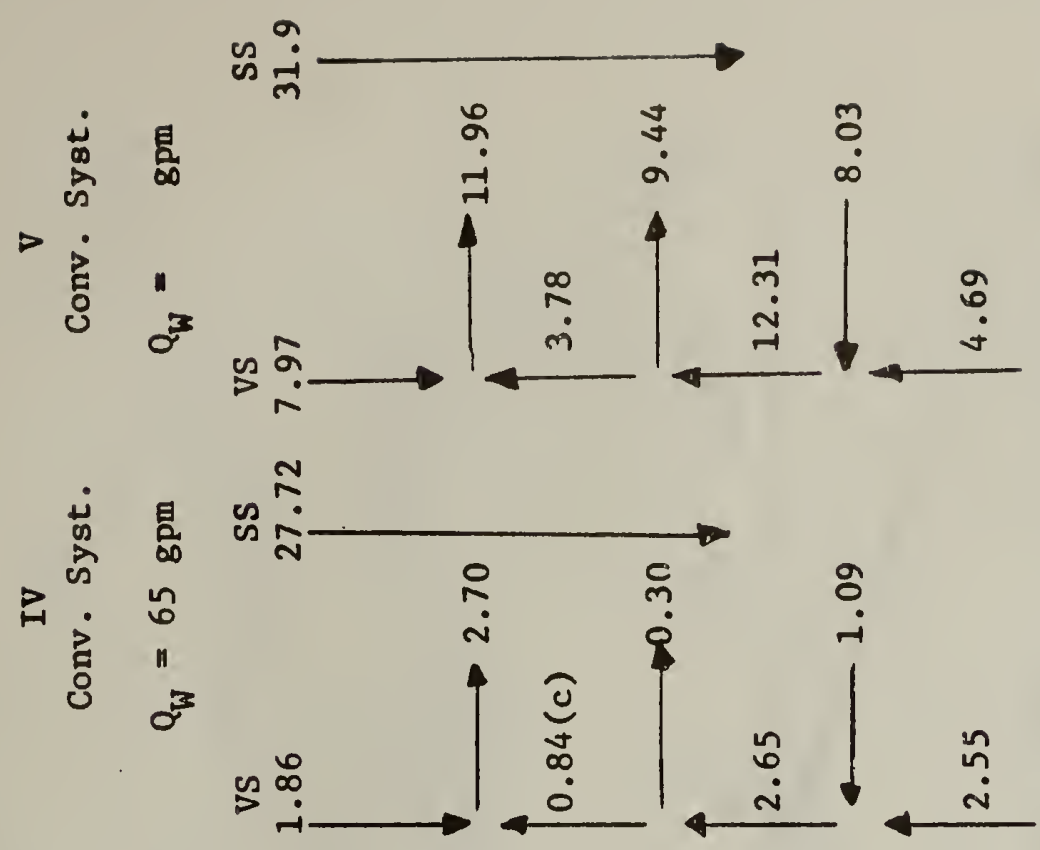

के

ผ $\stackrel{\infty}{\sim}$

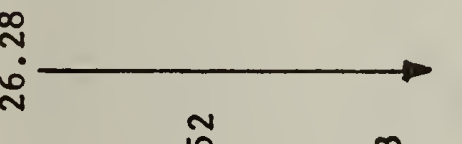



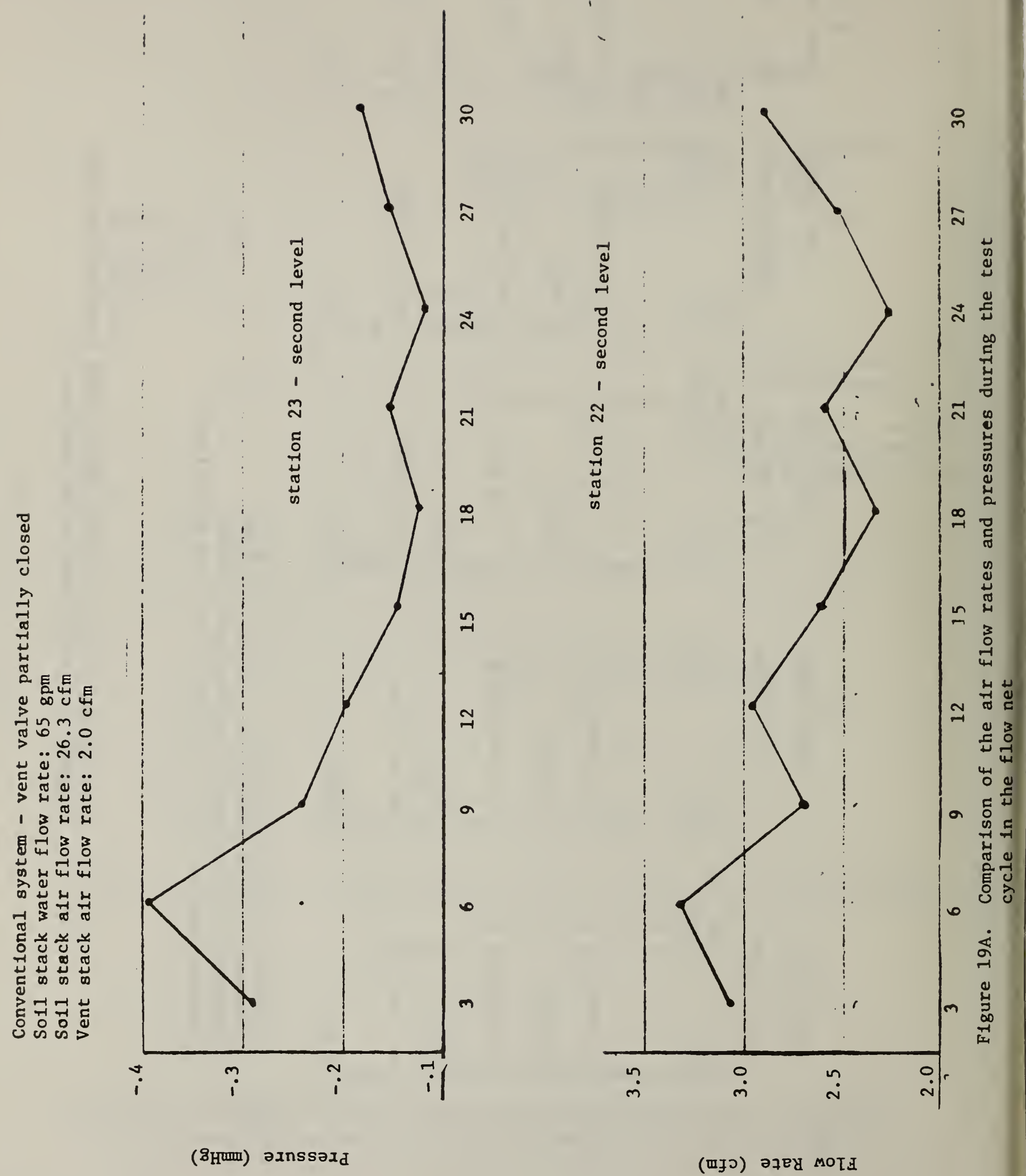

(ృ) әาЕу MOLI 

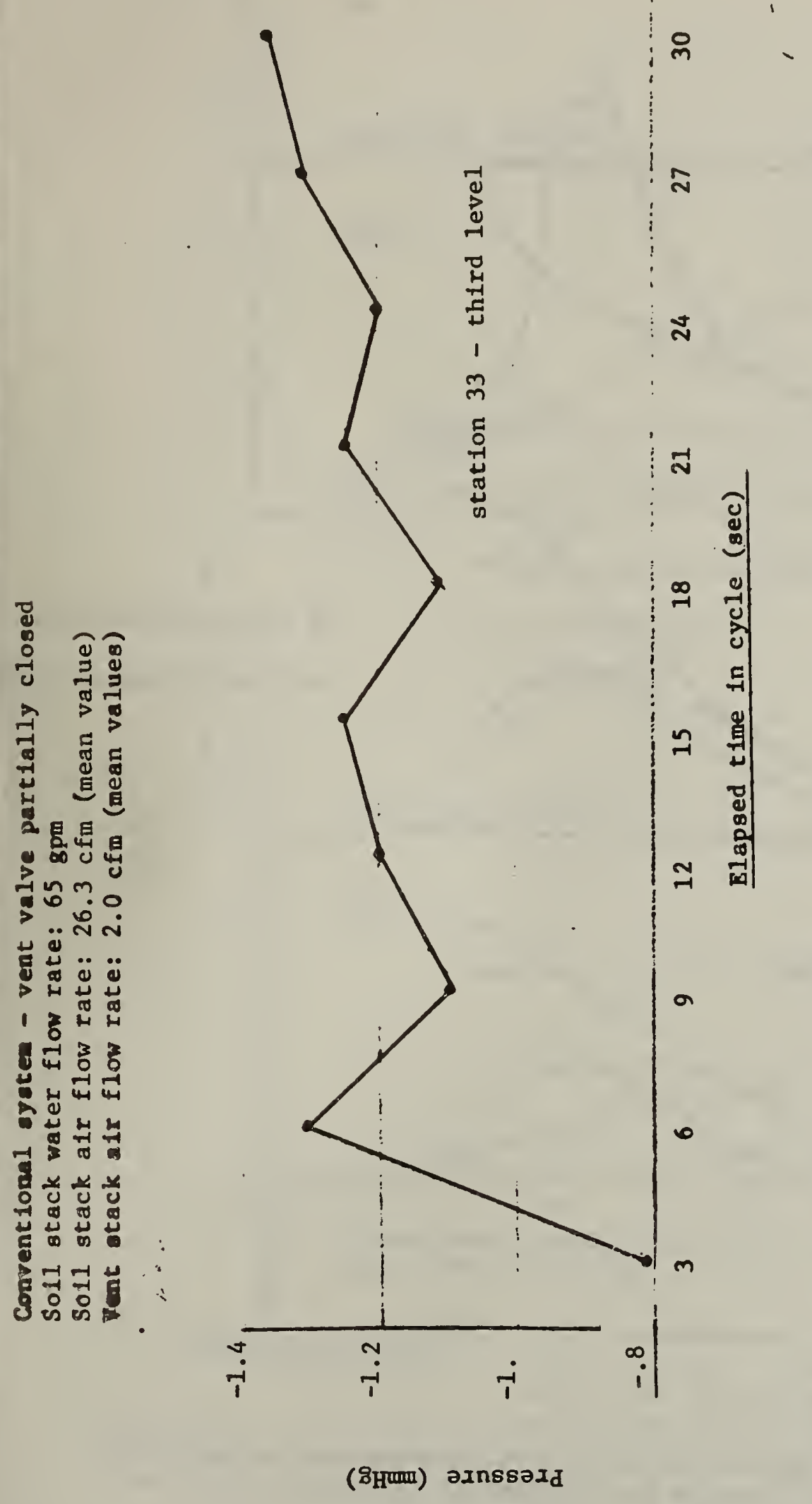

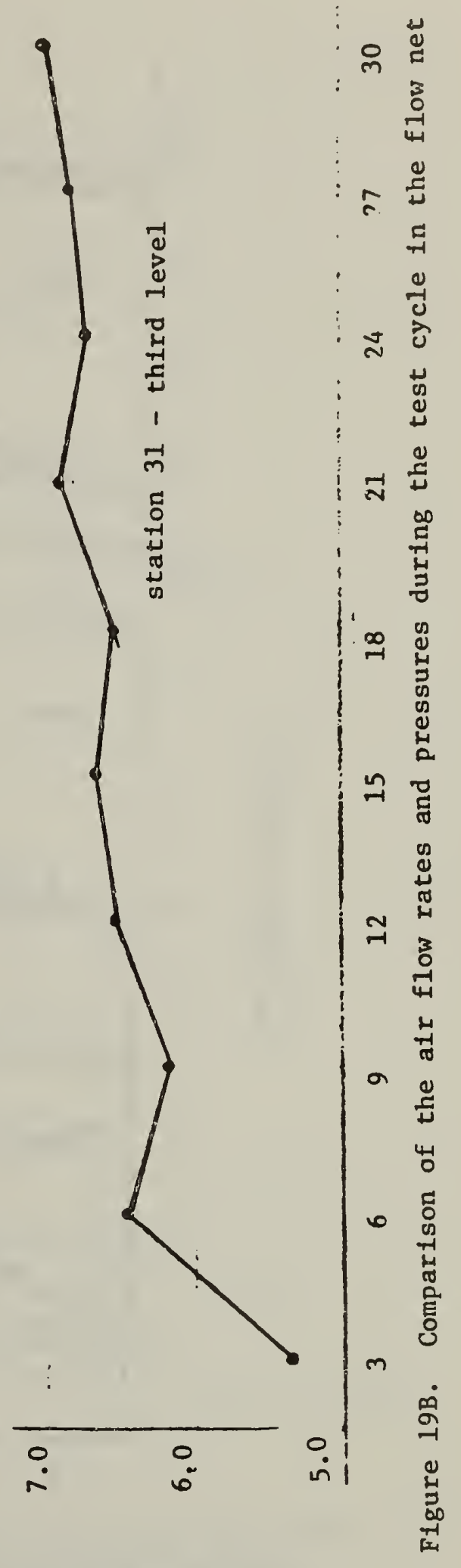

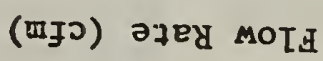




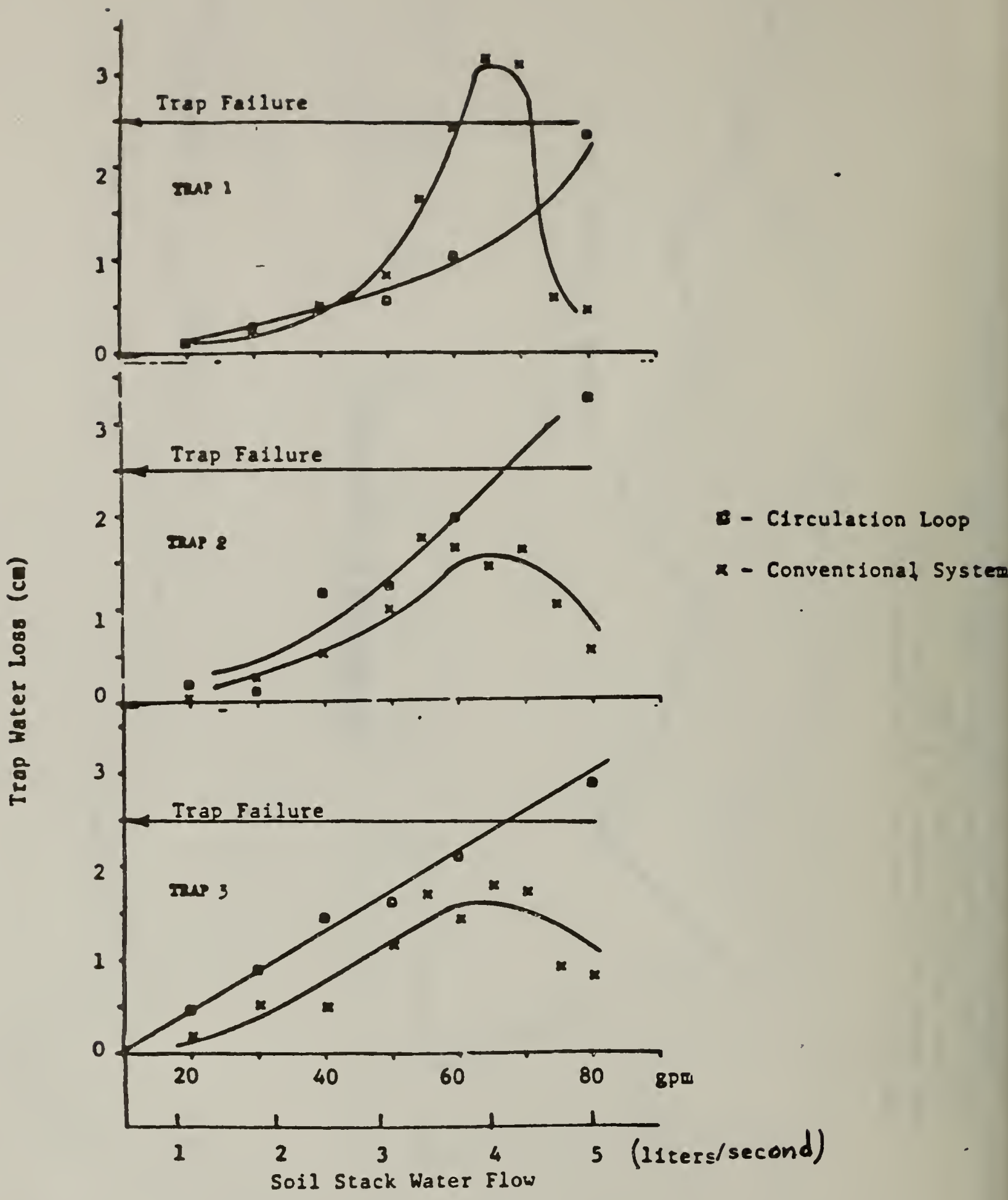

Figure 20. Depletion of traps 1, 2, and 3 as a function of the so1l stack flow rates (no fixtures active) for the circulation loop and the conventional system 


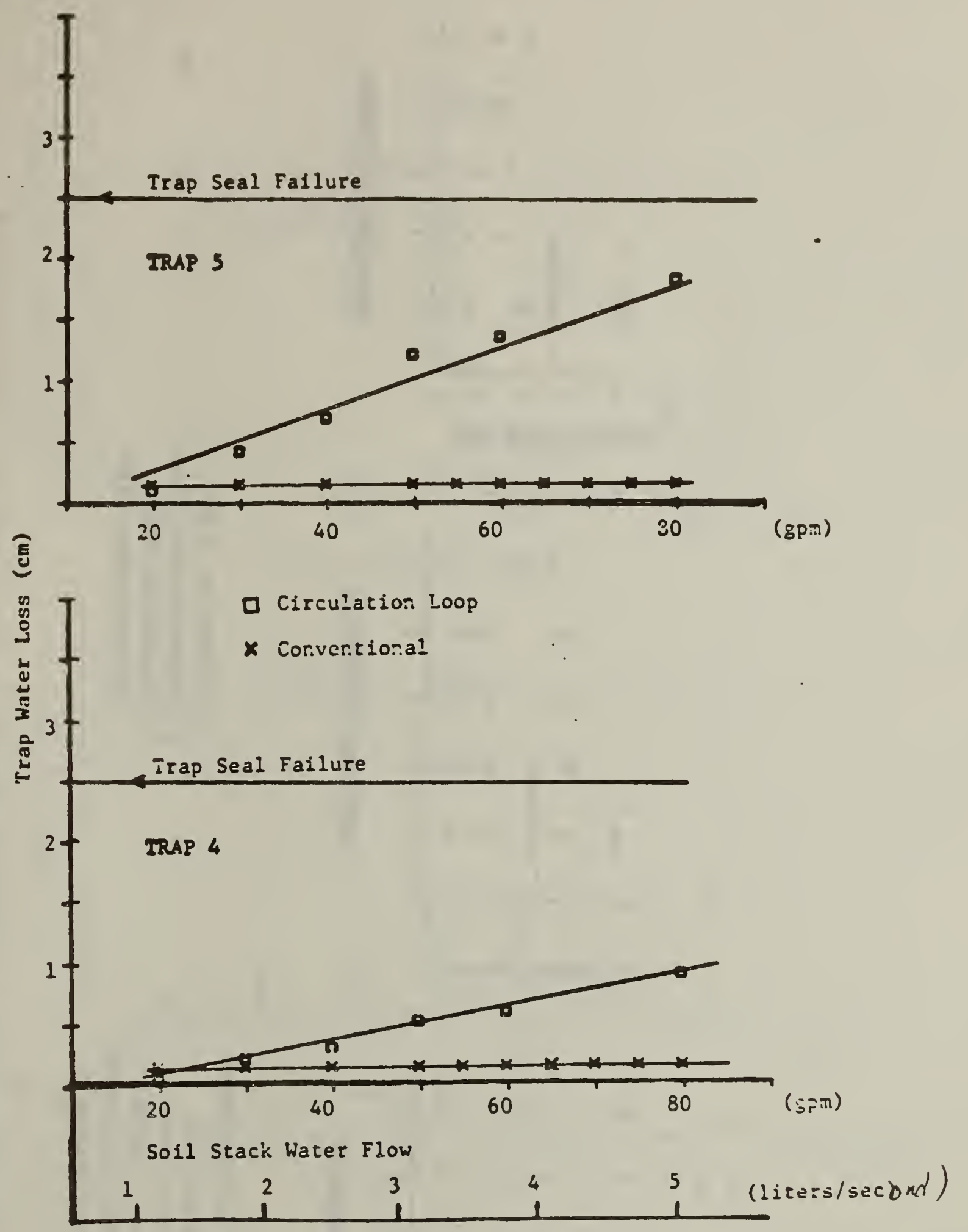

Figure 21. Depletion of traps 4 and 5 as functions of the soll stack flow rates (no fixtures active) for the circulation loop and the conventional system 


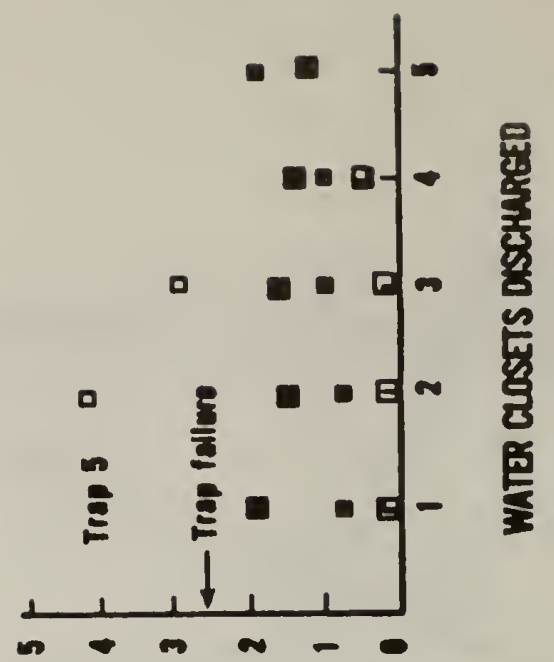

2

(யง) SSOT \&aIVM dral
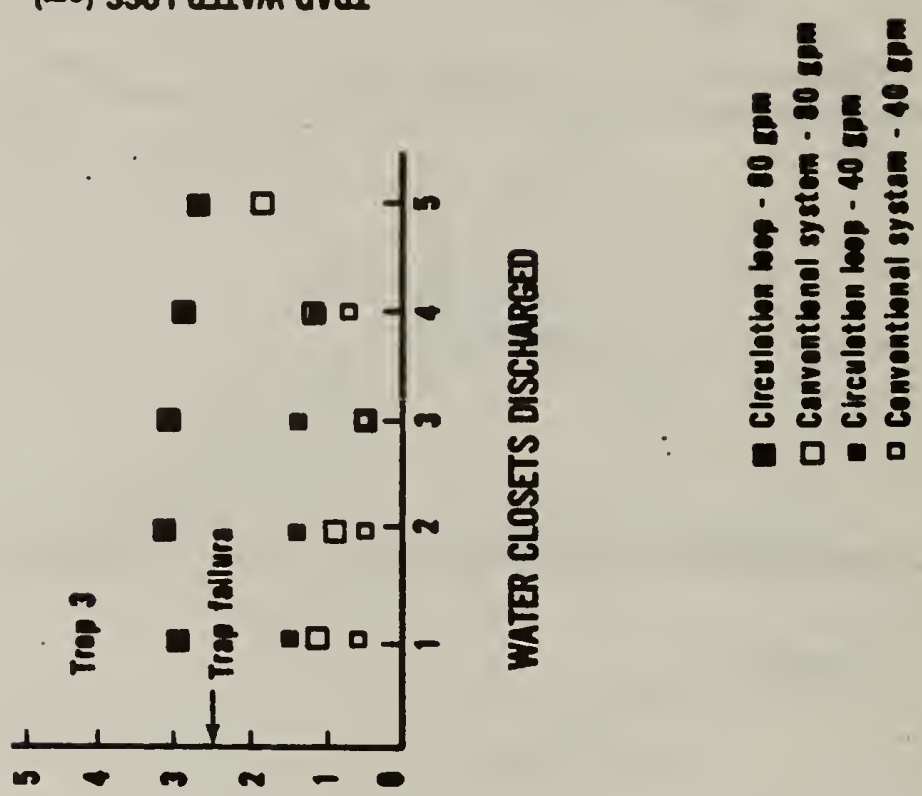

(แ⿰) SSOT \&IVM dVI
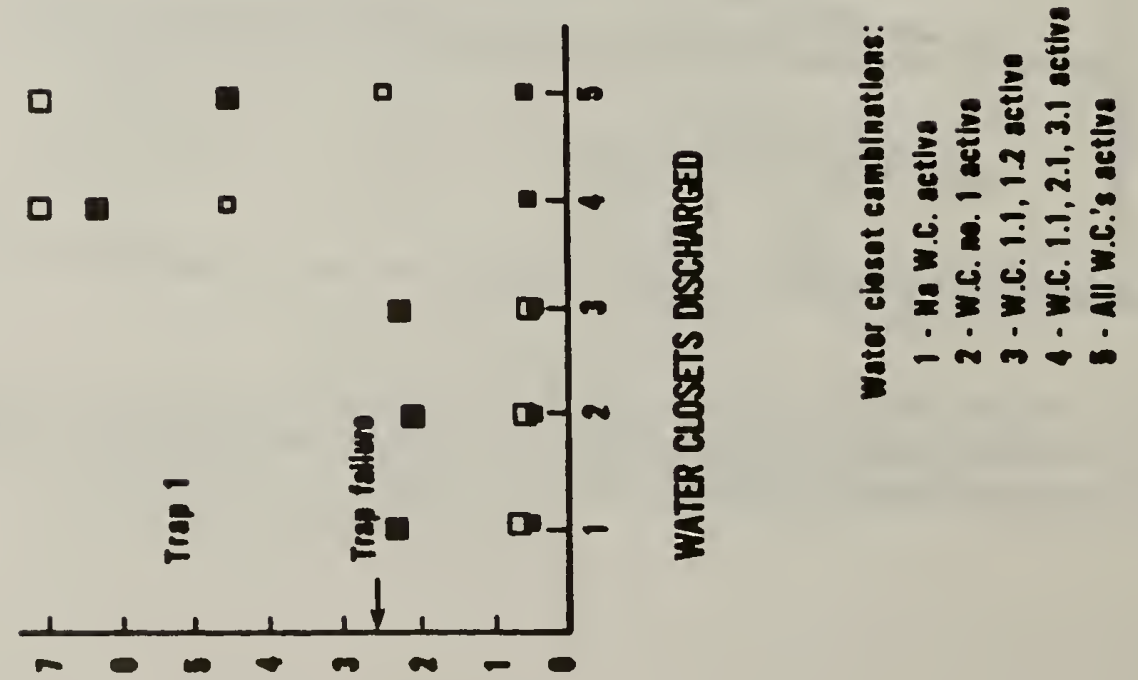

in

눈

ฮี

జ్

$\infty$

능 -

4웅

(⿻)

운 फु

光

वे के

$-\infty$

क

๘

कำ

岃

$\underset{\substack{N \\ 0}}{0}$

(W०) SSO GIYM dVAI 

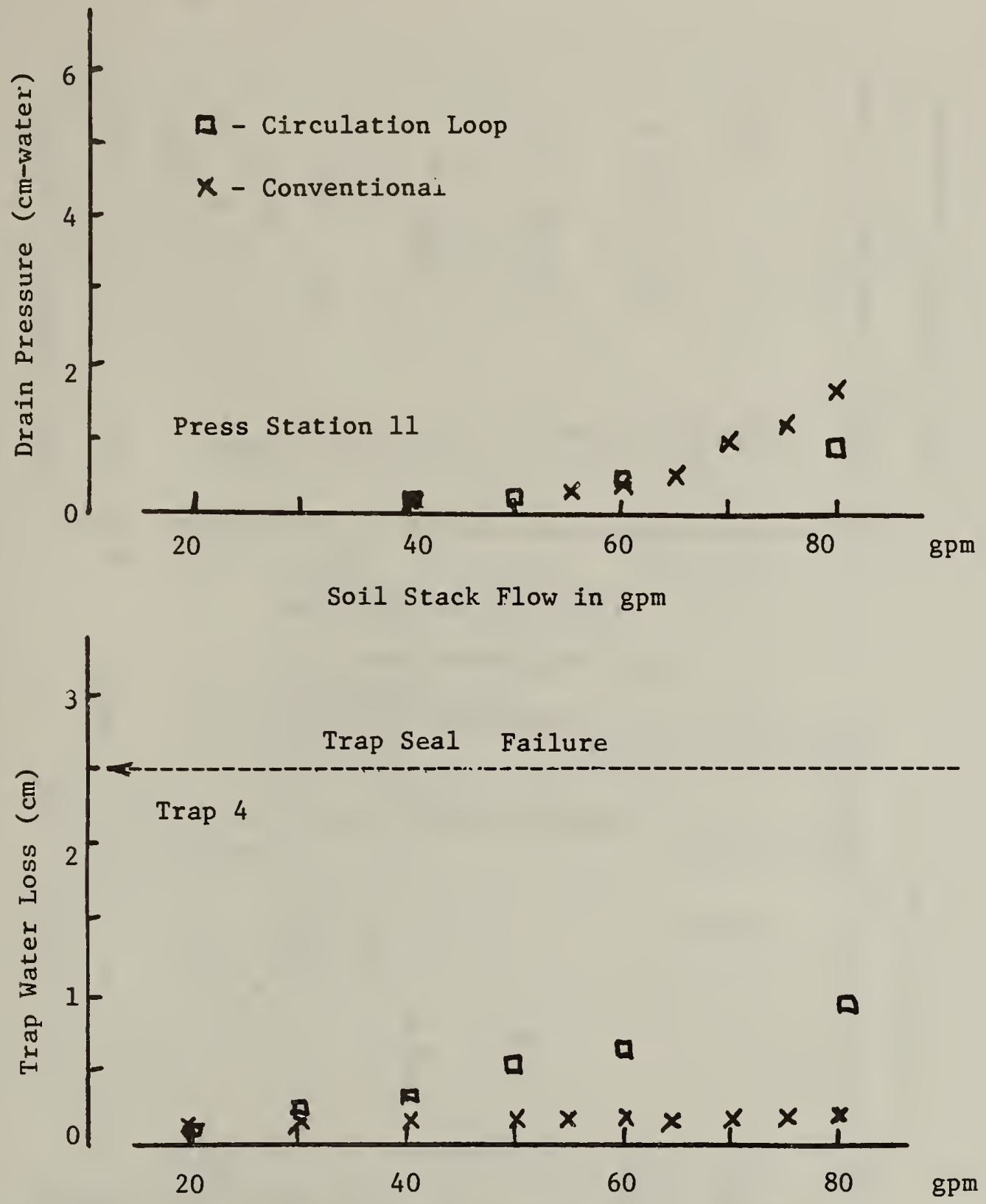

Soil Stack Flow

\begin{tabular}{|c|c|c|c|c|c|}
\hline 1 & 1 & 1 & 1 & $\perp$ & \\
\hline 1 & 2 & 3 & 4 & 5 & liters/second \\
\hline
\end{tabular}

P1gure 23A. Trap seal depletions and the corresponding static pressures in the drains as a function of the soil stack flow rates for the circulation loop and the conventional system 


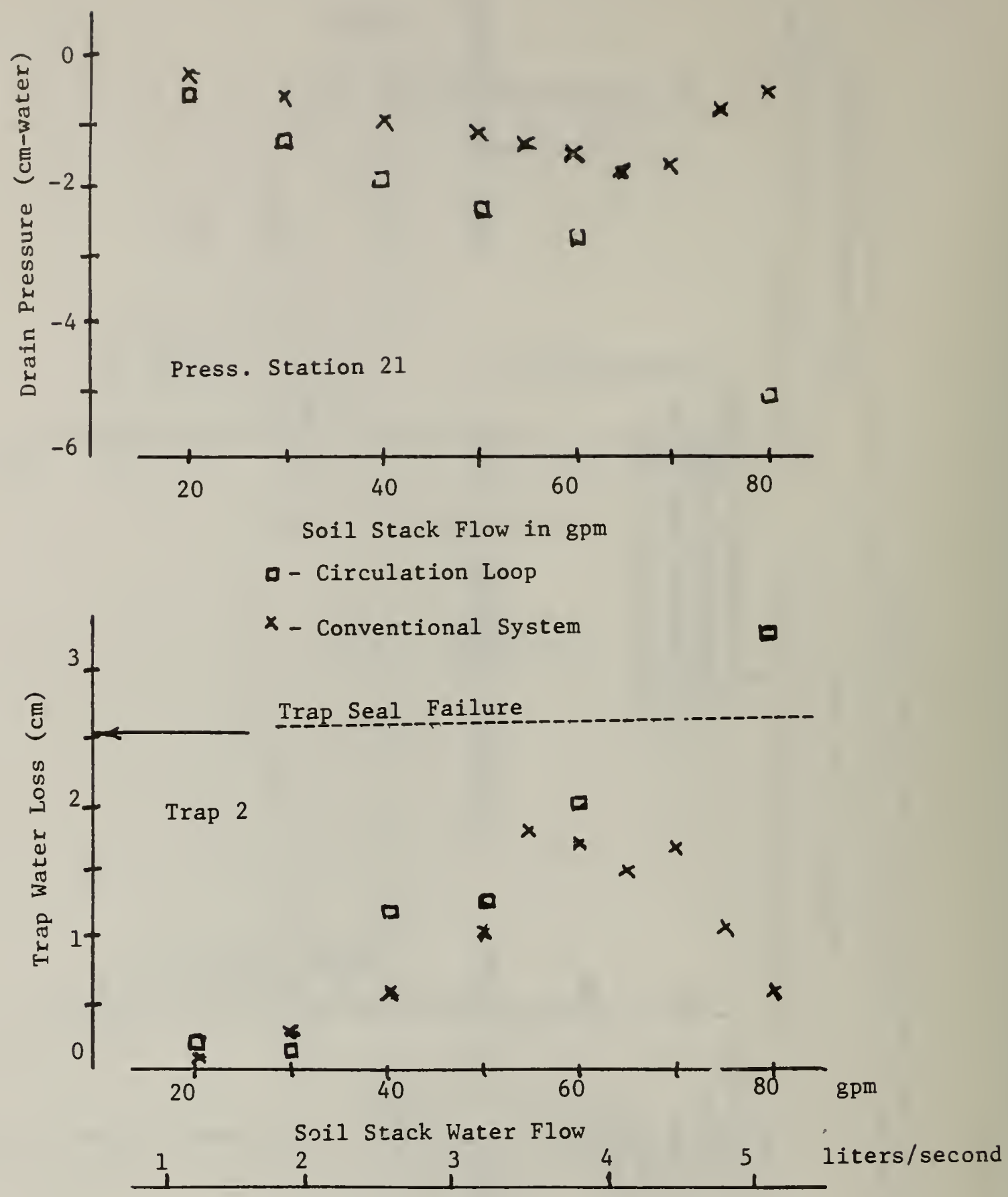

81gure 23B. Trap seal depletions and the corresponding static pressures in the drains as a function of the soll stack flow rates for the circulation loop and the conventional system 

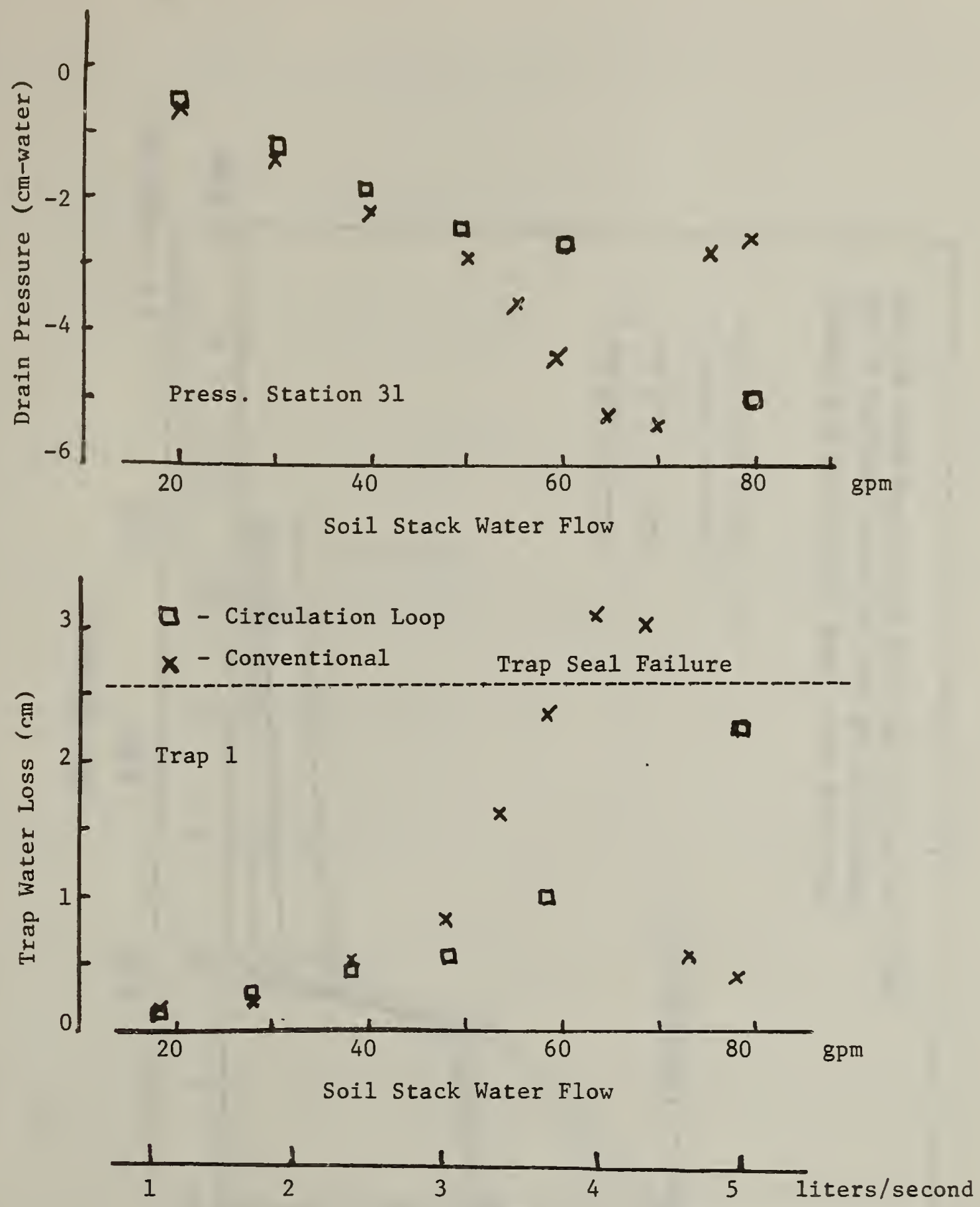

F1gure 23C. Trap seal depletions and the corresponding static pressures in the drains as a function of the soil stack flow rates for the circulation loop and the conventional system 


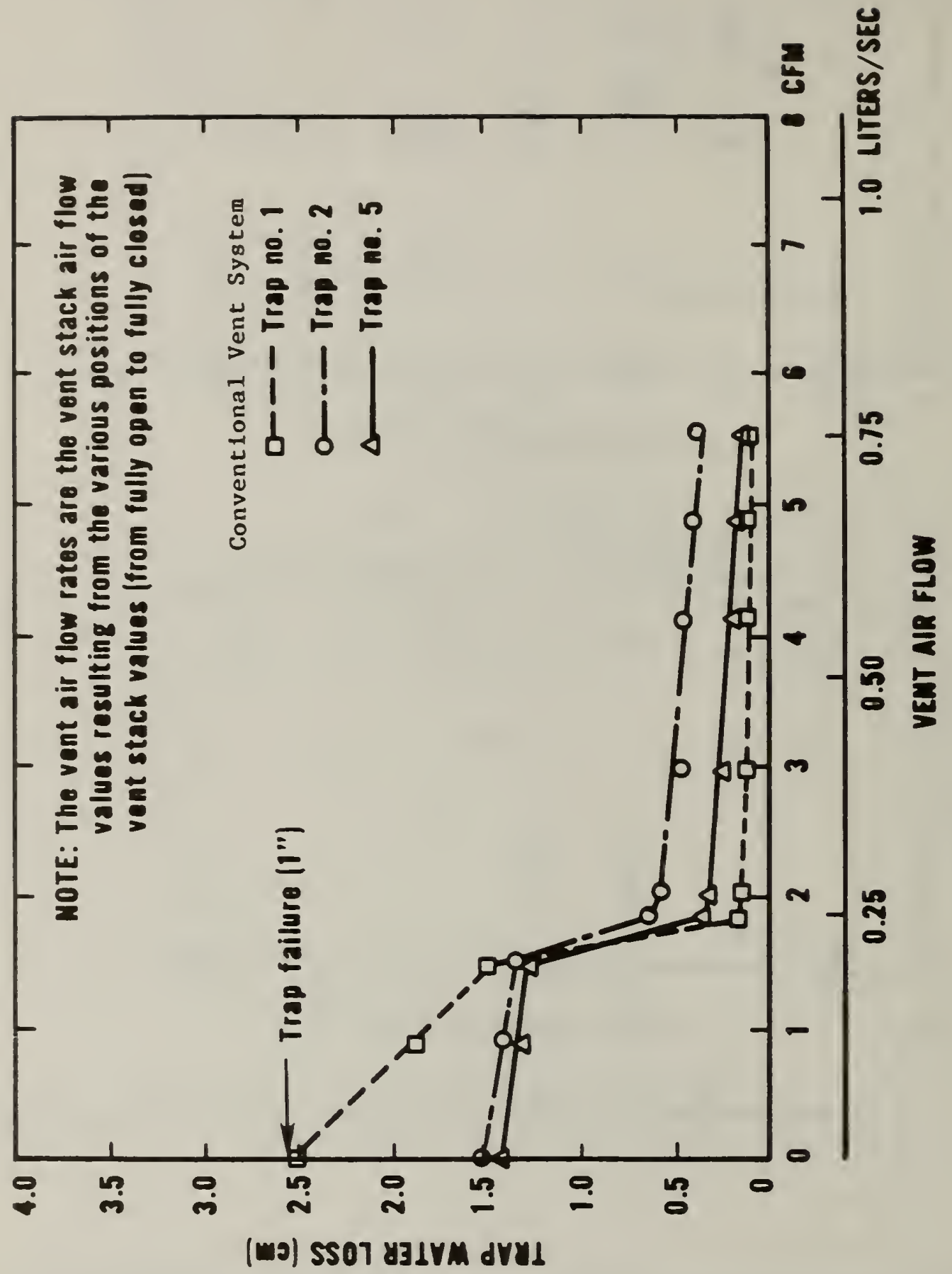

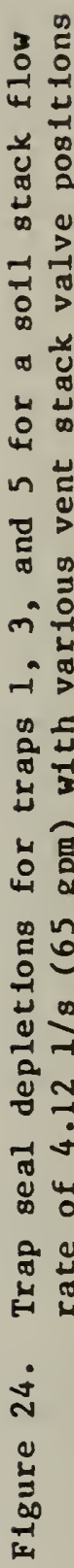




\section{Appendix 1}

Results of One Cycle Test Run 


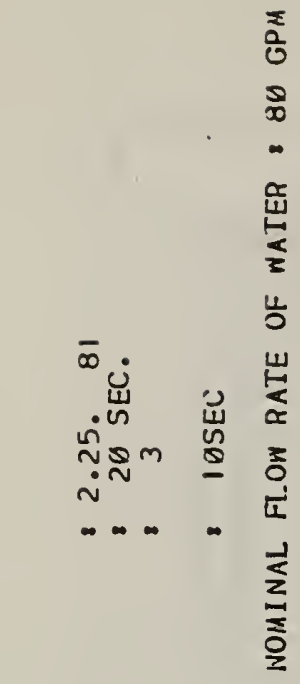

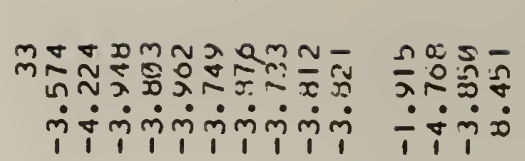

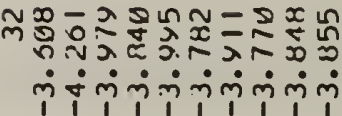

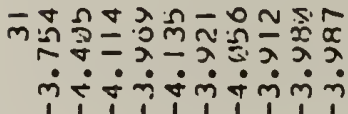

ำกำํํำ ำ? i

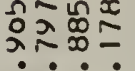 \\ $\div \dot{i} \dot{1}$}

芆

주요

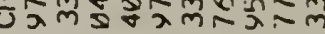

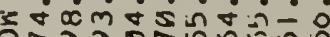

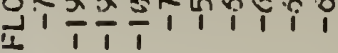

\section{- nopanmm}

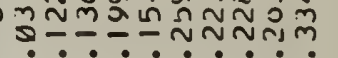

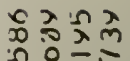

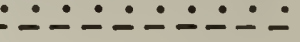
$\therefore \therefore 5$ $\overline{0}$

$\stackrel{z}{\beth}$

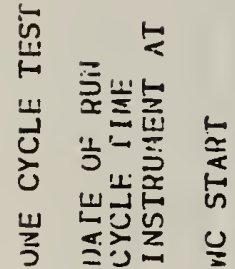

亗

点

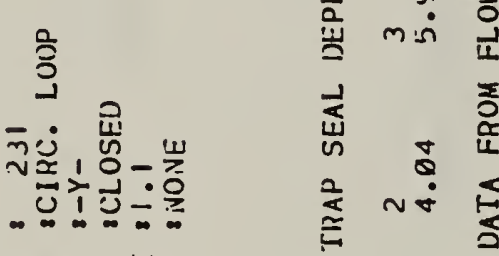

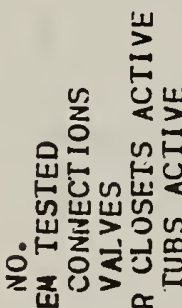

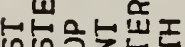

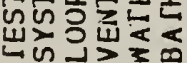

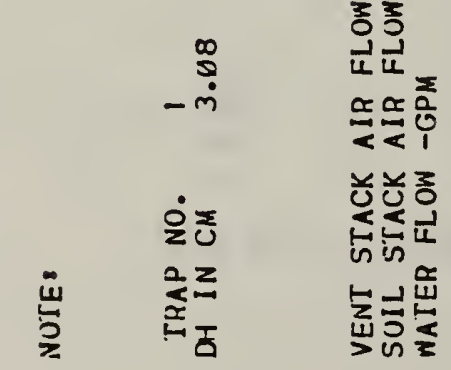

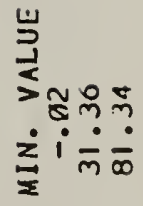

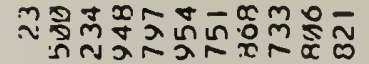
मेंलिलंलिलंल

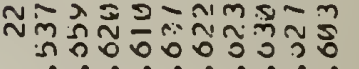
ํํำำ.

m্்ָ̃ ஸ்

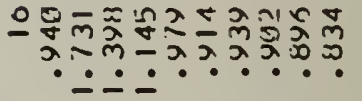

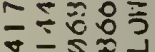
ठั

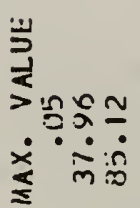

ฟิธิ์

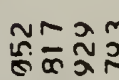

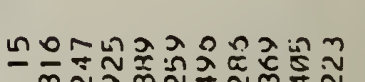

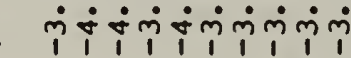
iं $\dot{i} \dot{i}$

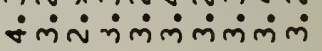

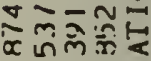

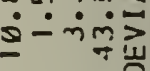

$\sum$

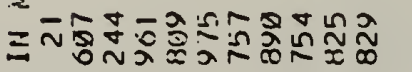

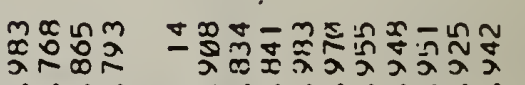
-

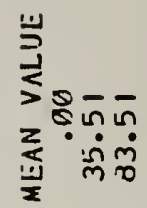

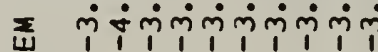
†िभिक 管

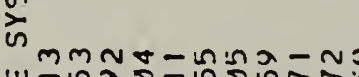

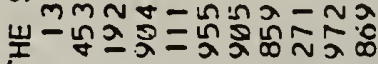

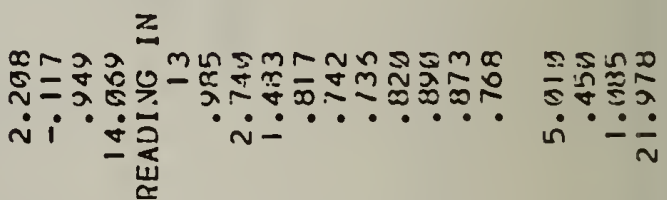
$z$

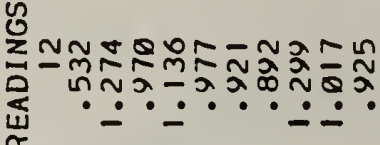

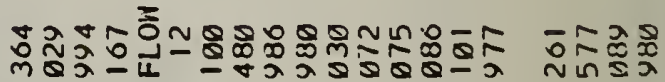
î.

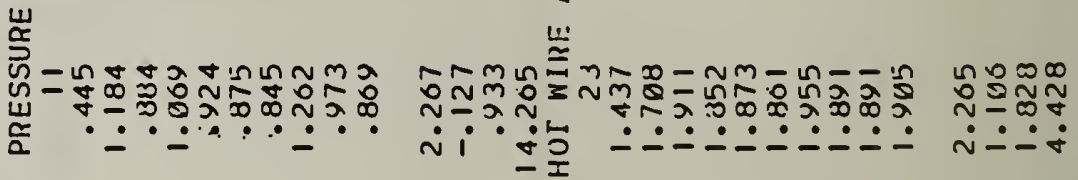
妾壳

ㅎํำ

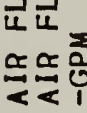

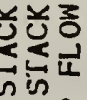
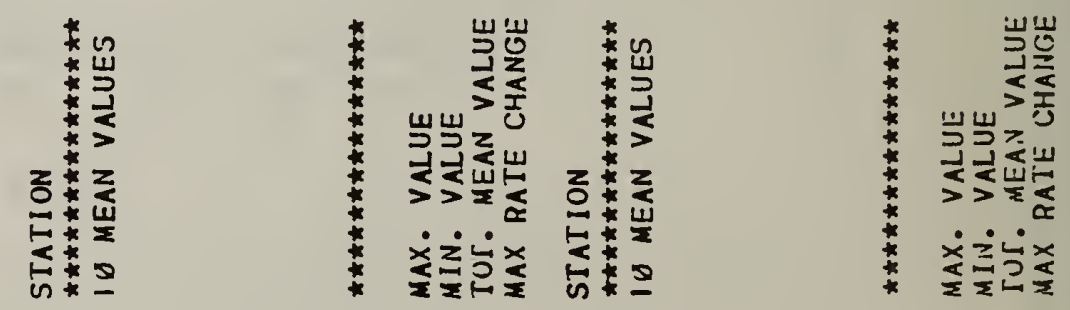
$\dot{i} \cdot \dot{i}$ 


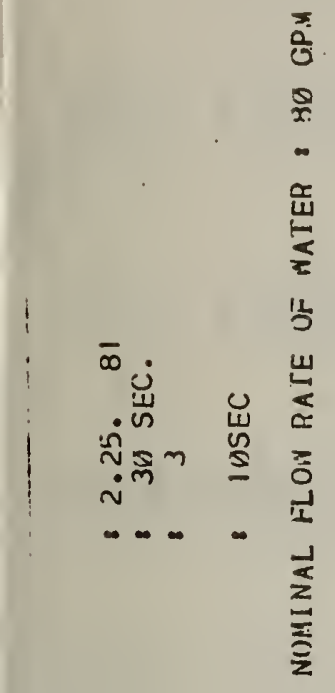

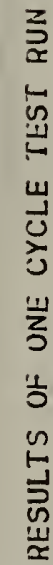

oे 㟔 mm

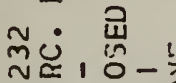

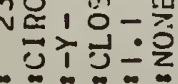

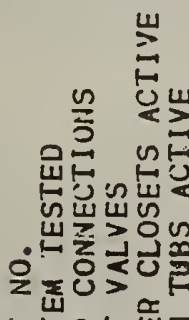

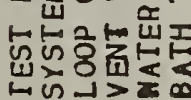

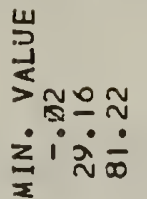

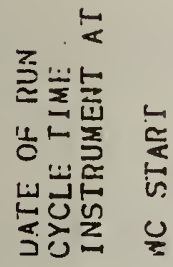

岕

衣 ก

3
$-\dot{0}$

巳巳z

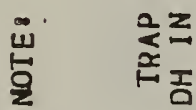

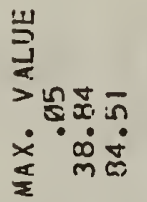

岁

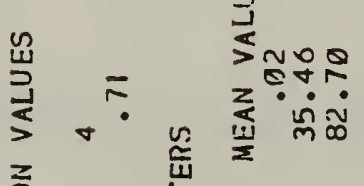

竞党

옹엄

뜬인

弟关志

解总 mุตำㄴำ

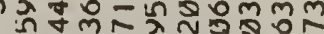

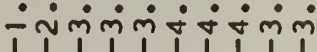

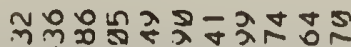

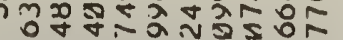

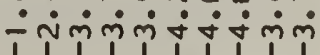

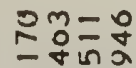
- $\because \dot{i} \sim$

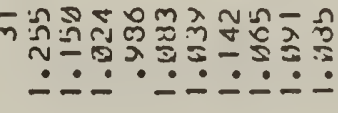

กิำำ निभिजि

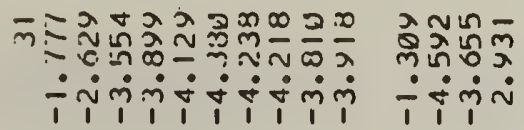

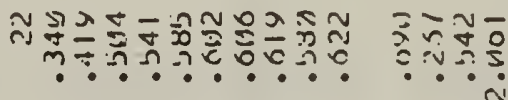

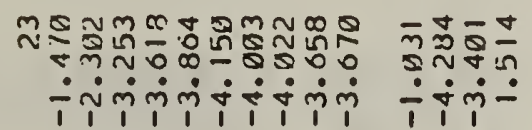

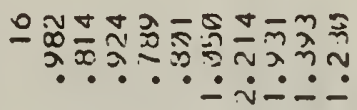

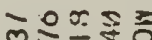

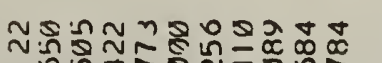

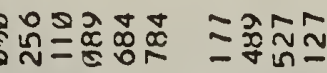

†ंभिं

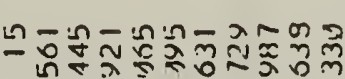

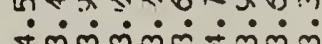

ก⿻上丨丶

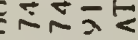

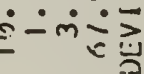

$\Xi$

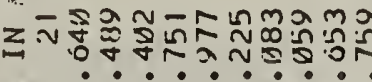

îّ

$\sum_{i=1}^{\pi}$

分

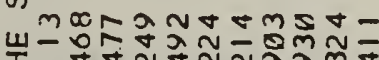

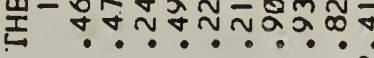

$\Xi$

?

荡

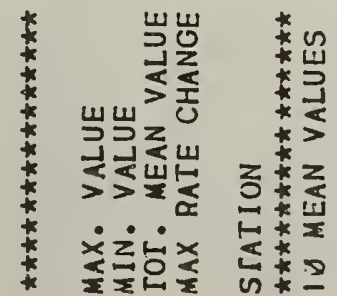

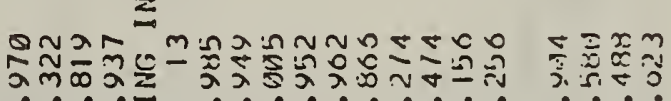

i

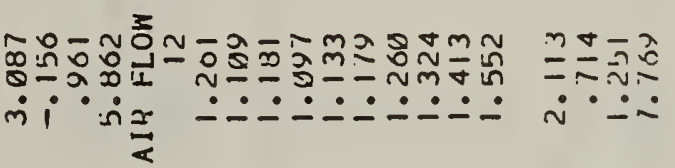

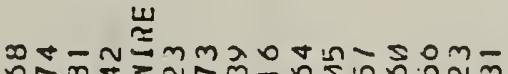

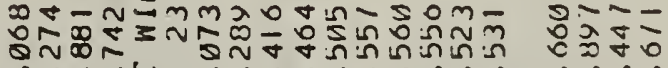
mi 战

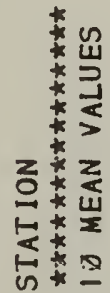

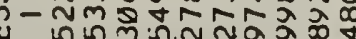
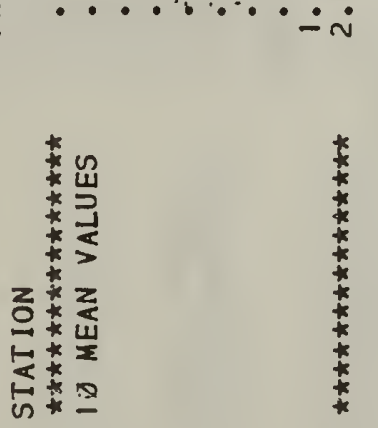

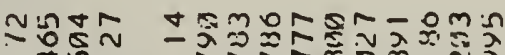

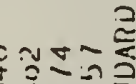

$\therefore x-3$

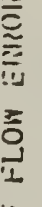




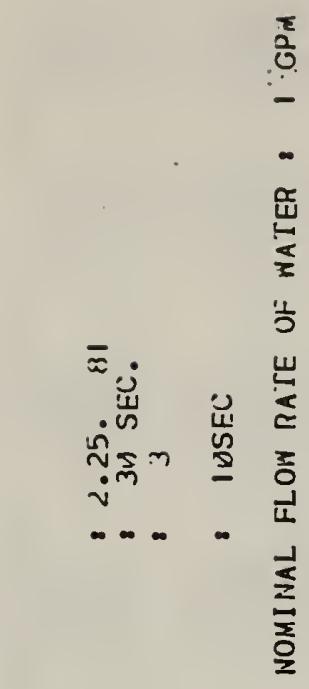

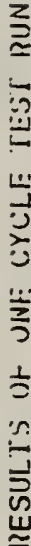

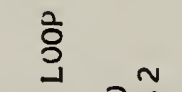

ก.:

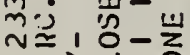

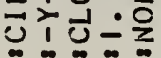

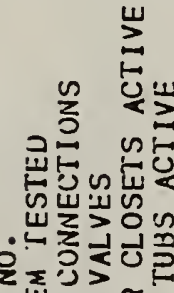

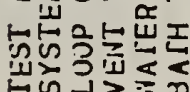

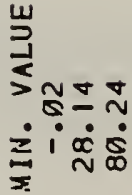

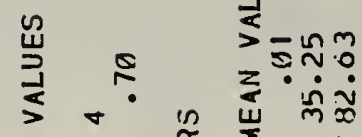

岂

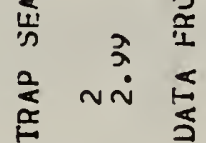

恶突

홍

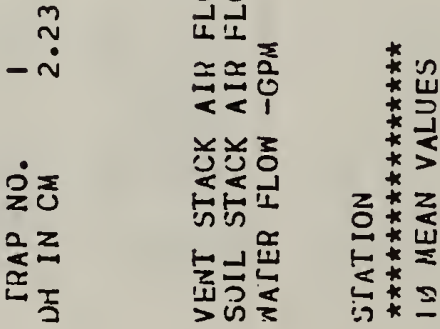

岂

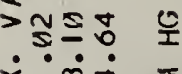
爻

岌

$z$

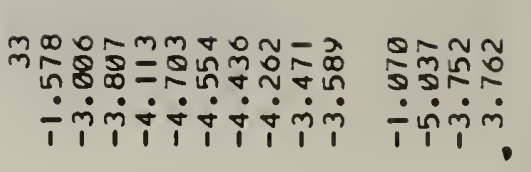

se

芩

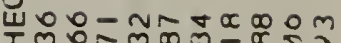

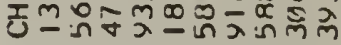

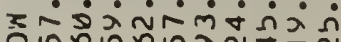

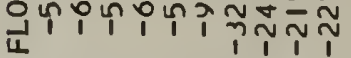

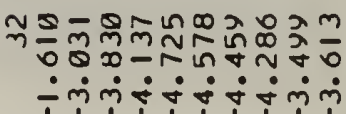

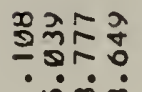

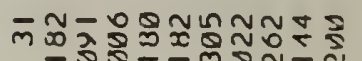

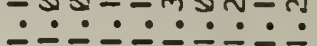

\begin{tabular}{l}
$x+\infty$ \\
$\approx$ \\
$\approx$ \\
\hdashline
\end{tabular}

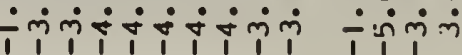

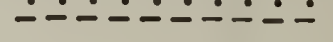

$\because \dot{-1} \frac{\Omega}{\Omega}$

-

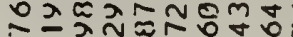

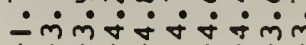

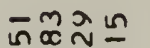

กำ

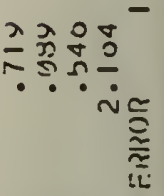

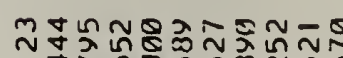

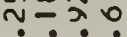
-ெं்

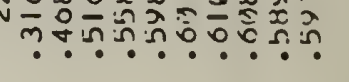

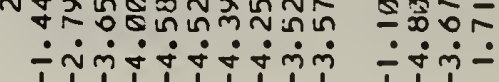

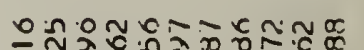
ำกวำ产

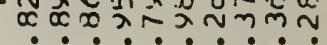
نं山ंn $\therefore: \div=\overline{1}$ $\ddot{0}$

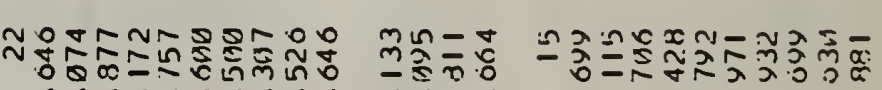

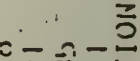

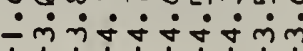
-िं்

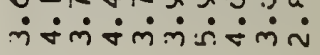

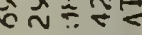

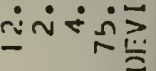

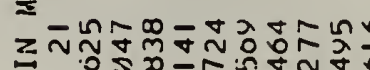

毛

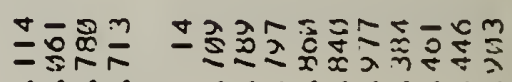

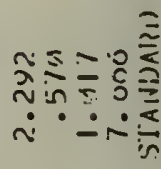

क

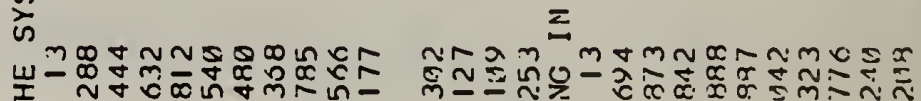

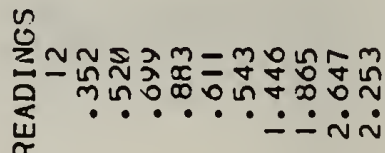

î:

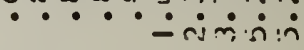

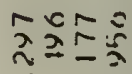

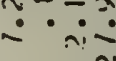

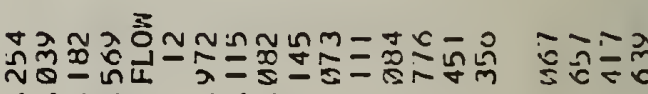

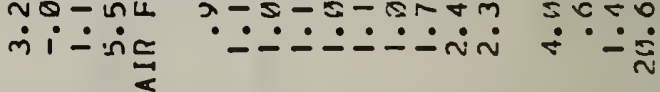

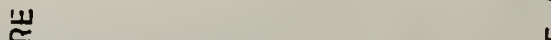

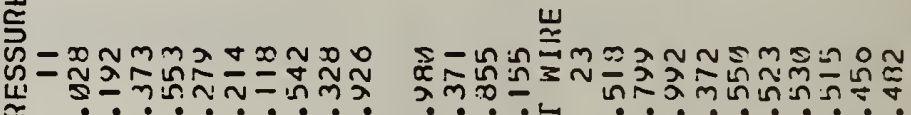
辛 $\dot{\sim} i \cdot \dot{0} \underline{c}$

欲六交 cथ?

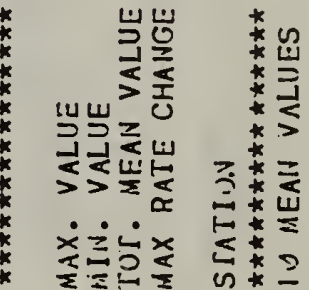




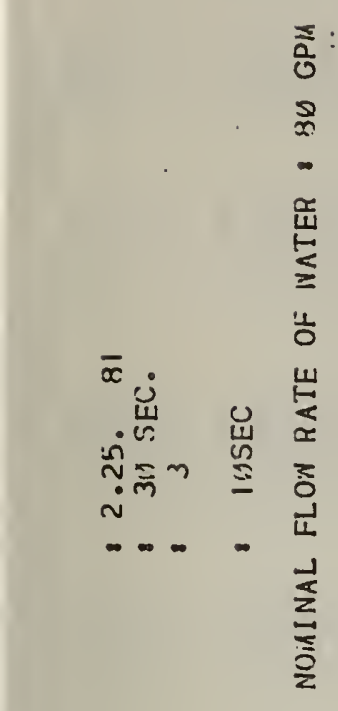

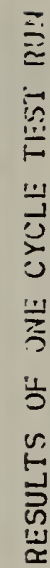

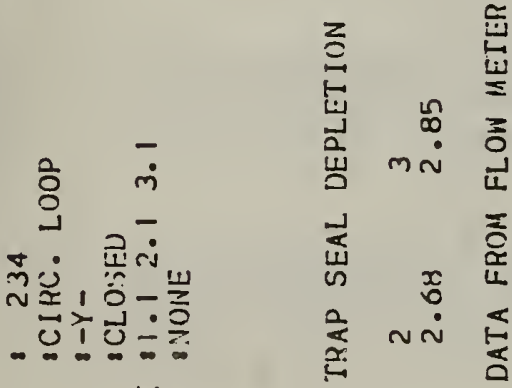
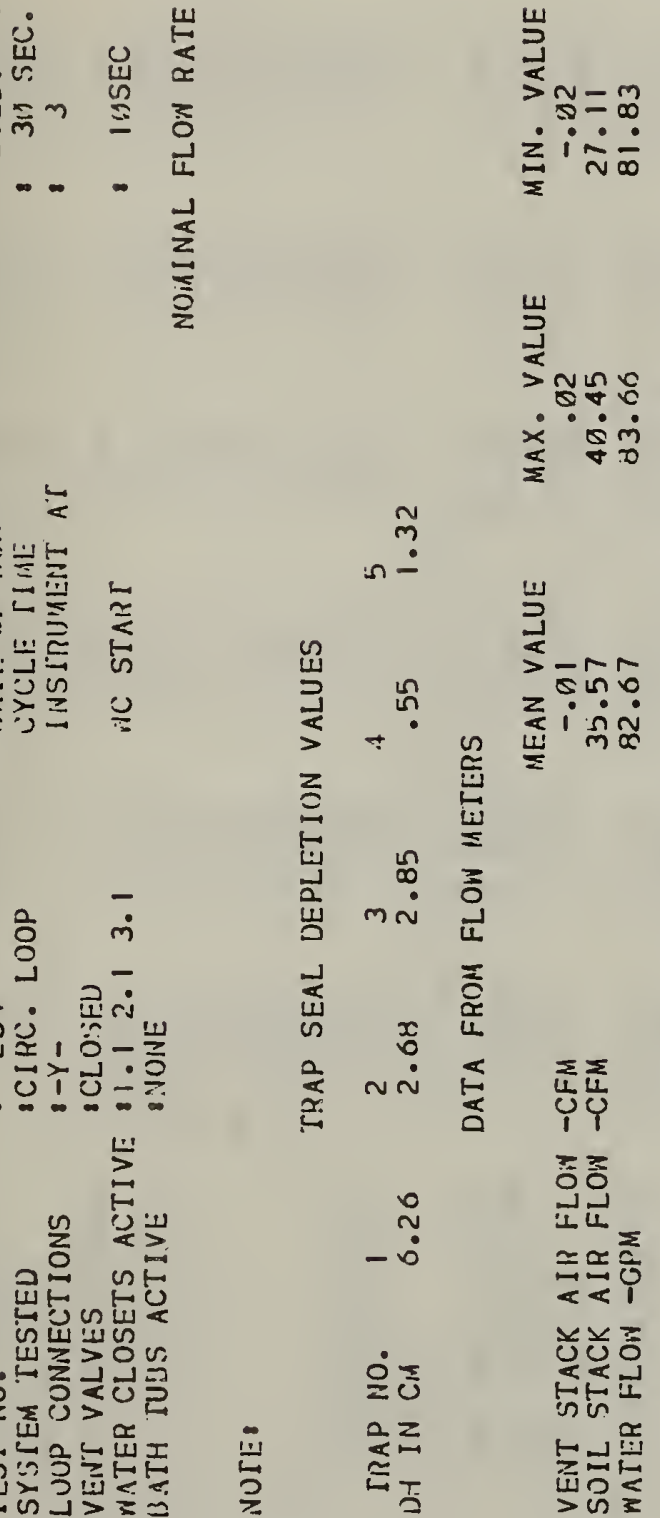

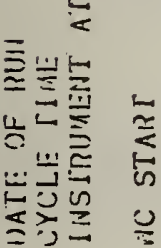

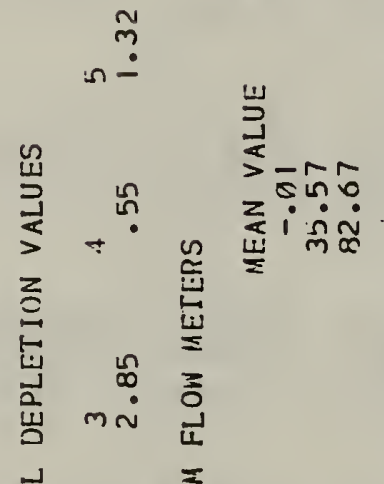

ș

U⿺辶

프응

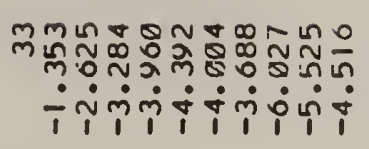

$\sim \operatorname{mn} \infty \sim \infty \ln \infty \theta$ ก 0

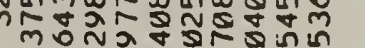

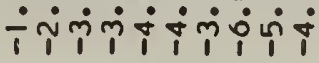

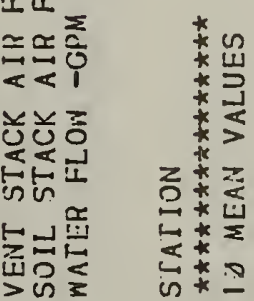

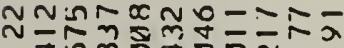

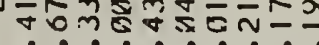

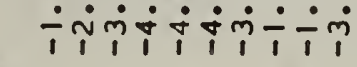

$\bar{z}$

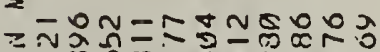

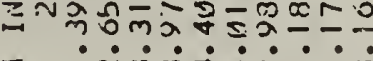

妾

永

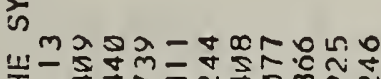

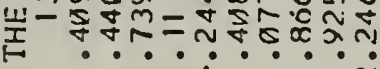

z

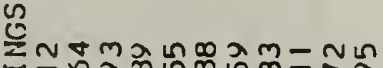

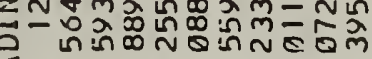

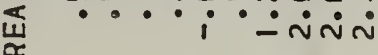

㞻

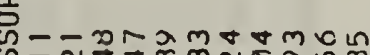
แี 똥

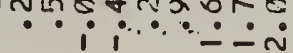

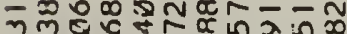 ถ์ -}

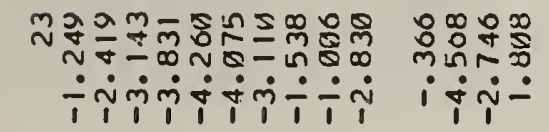

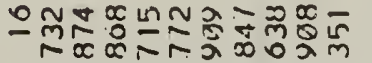

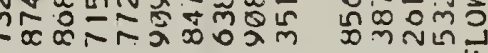

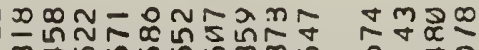

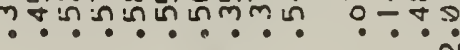

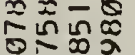

$i \dot{\sim} \dot{\sim}$

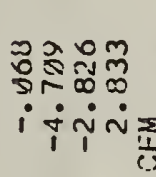

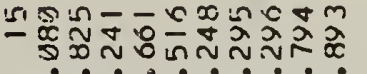

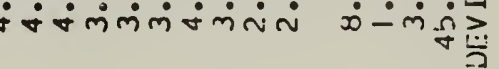

$\infty \cdot 0, \infty$

근

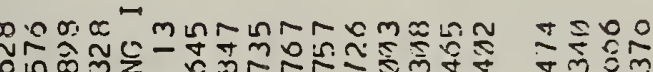
iं is

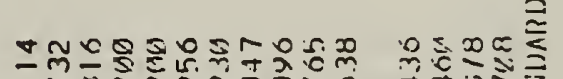

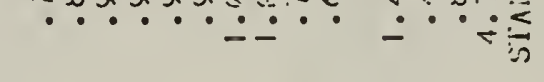

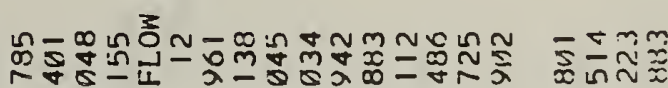

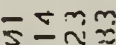

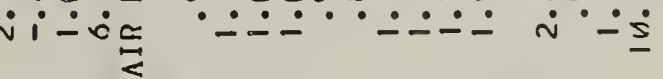

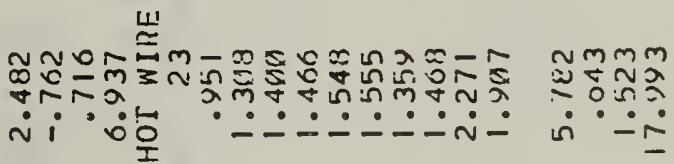
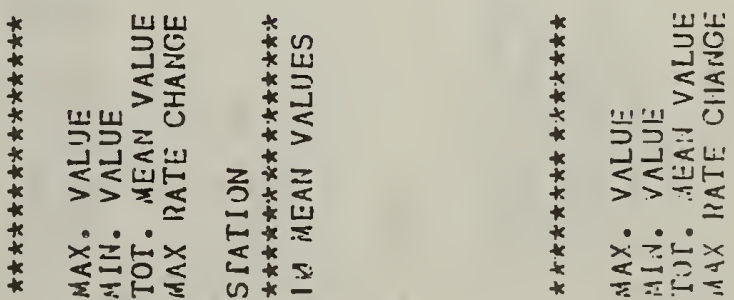


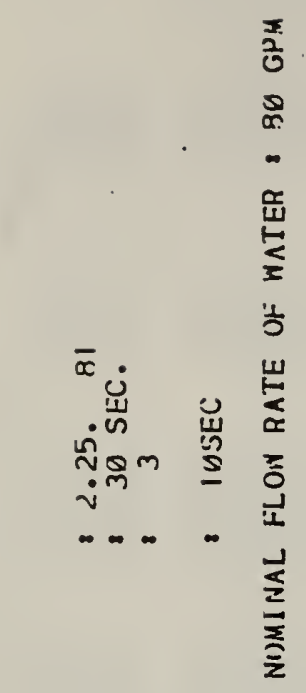

ב-

วั)

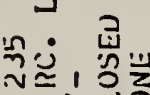

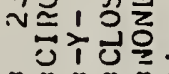

를

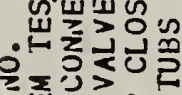
준일

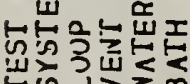

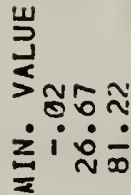

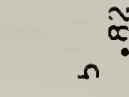

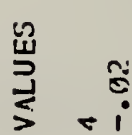

홍

㟧

宅 $\sim \dot{\sim} \leqslant$

준진

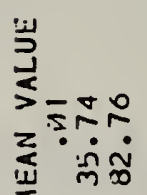

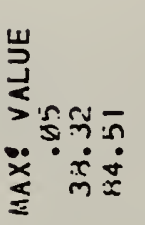
종중

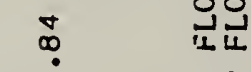

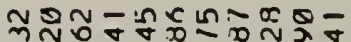

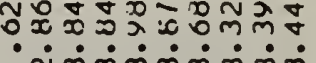

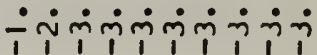

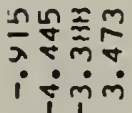

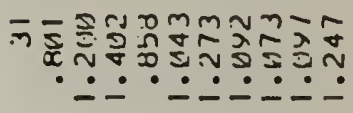

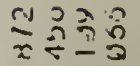
- $\div \dot{\mathrm{c}}$

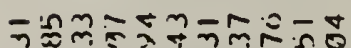

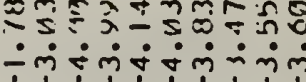
E.ㅇㅇㅇㅡ

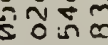
$\dot{i} \dot{i}$

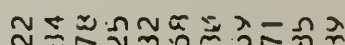

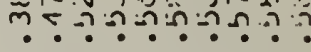

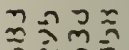
约

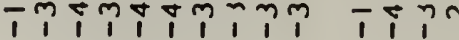

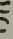

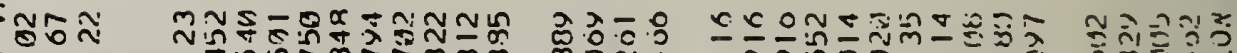
i这

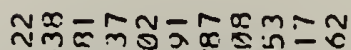

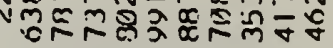

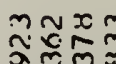
iिं

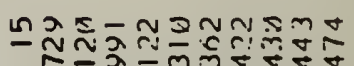

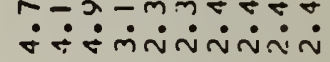

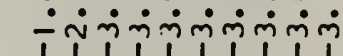

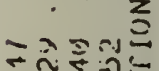

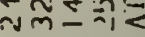

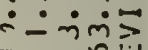

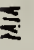

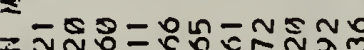

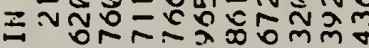

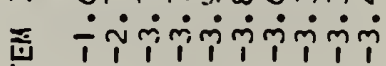

xิ

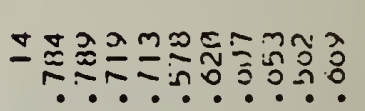
in

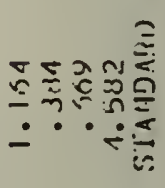

\section{元}

岂

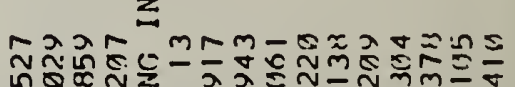

ำำ 3

$\dot{m} \because \dot{x}$

$\because \cdots \cdots$

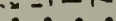

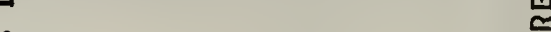

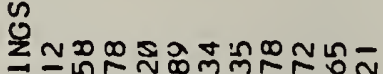

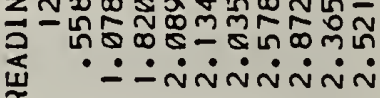

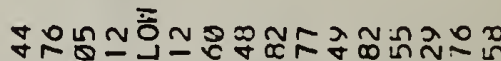

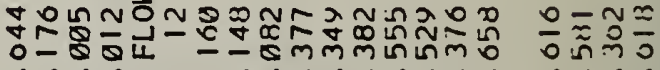
₹

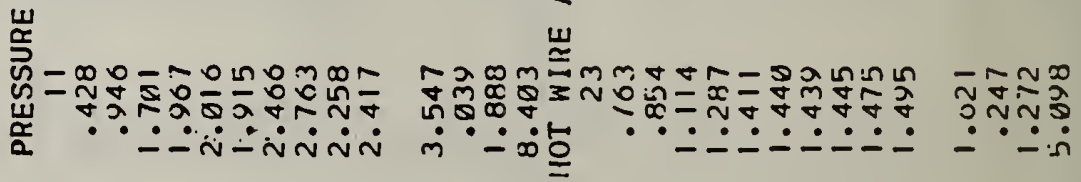
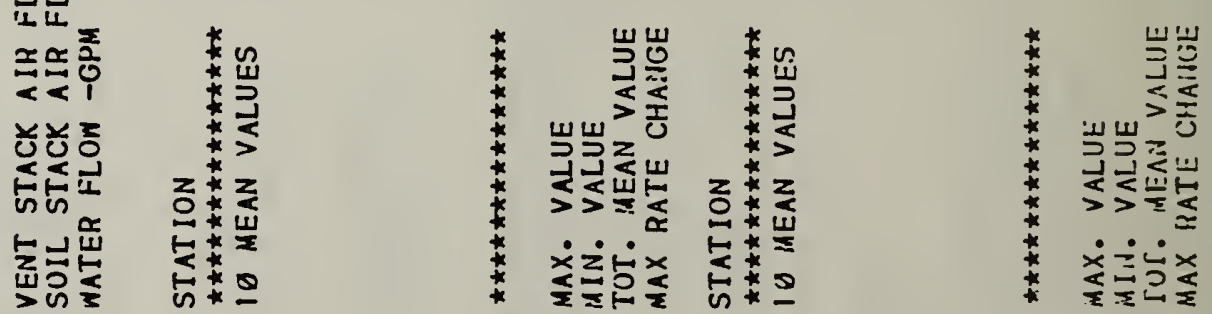


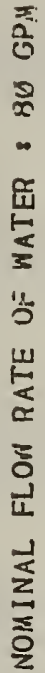

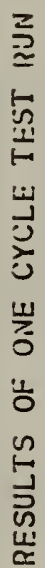

这

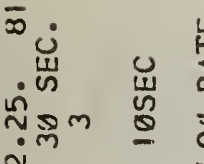

岂

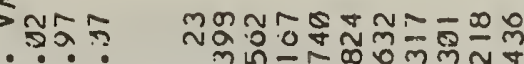

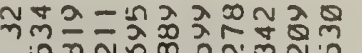

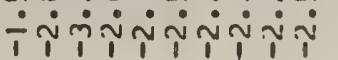

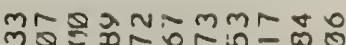

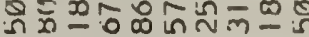

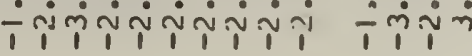

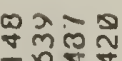

se.

芩

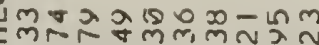

STSL-

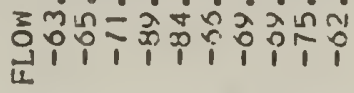

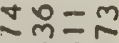

m

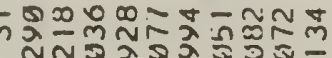

กิ

$\therefore-10 \div$

$\therefore-\dot{\text { in }}$

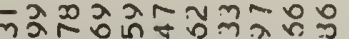
○入 लळ

$M=Q N$ -

กิธต์

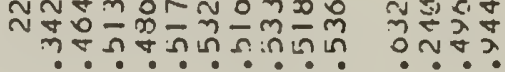

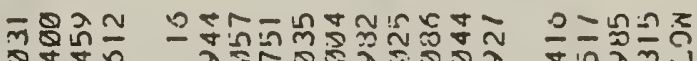

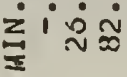

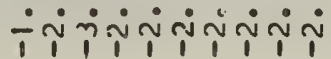

- ini-

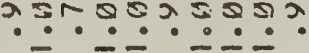

$\because \because \frac{\pi}{2}$

岁

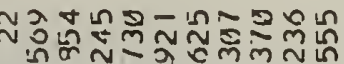

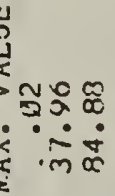

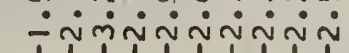

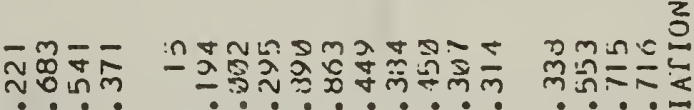

这豈

$\bar{\ddots}$

宸

岇

zัง

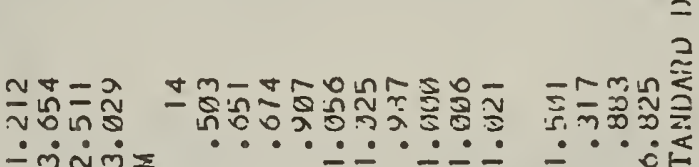

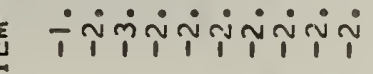

-iिं

$\stackrel{\sim}{\circ}$

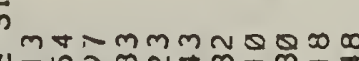

以ำ

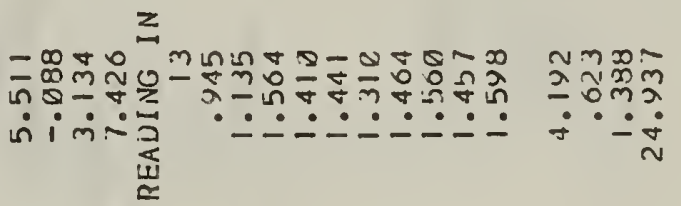
z

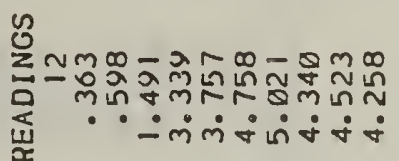

ㄸำ

$\infty-\frac{\pi}{2}$

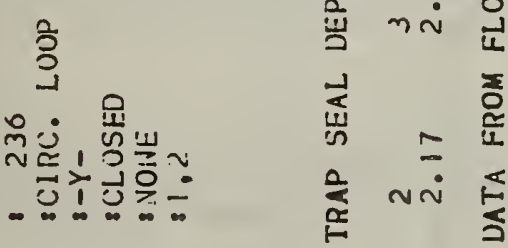

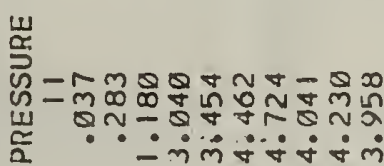

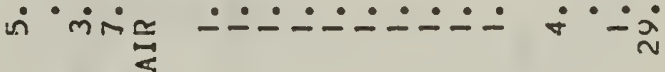

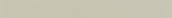

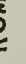

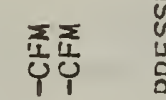

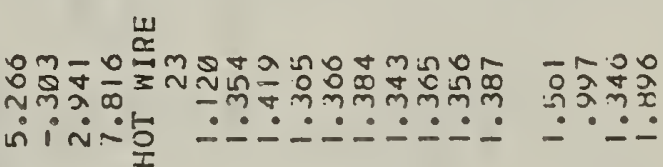

증중

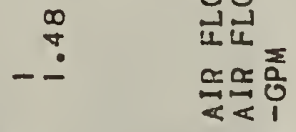
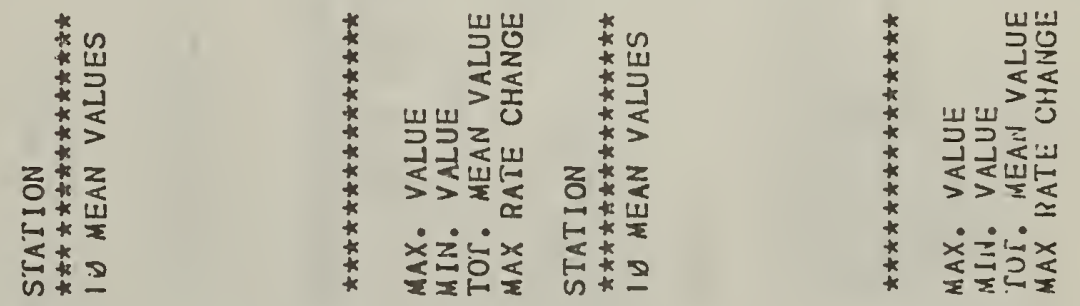

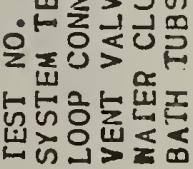

울른

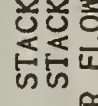

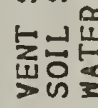

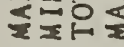




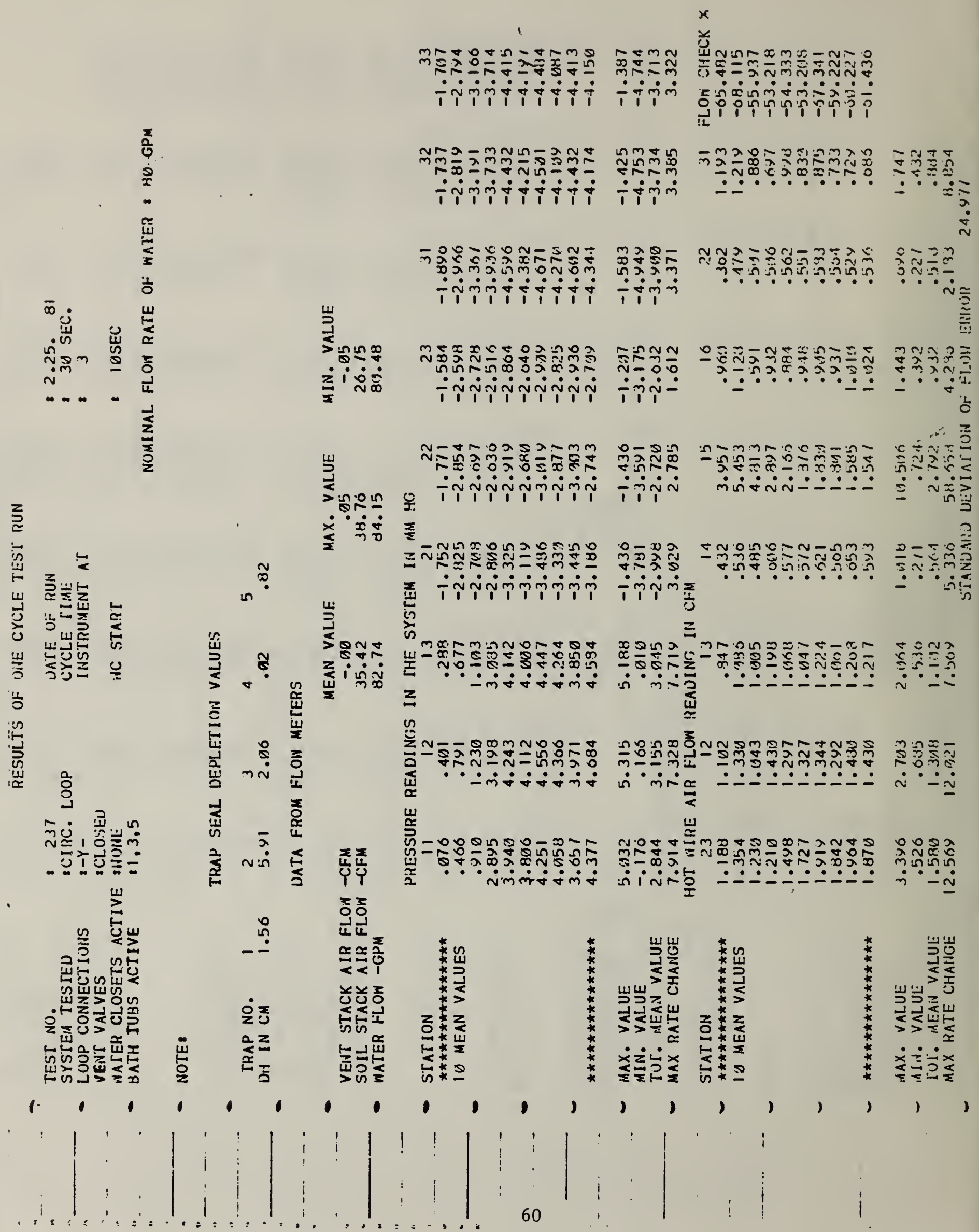


ปे

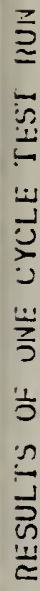
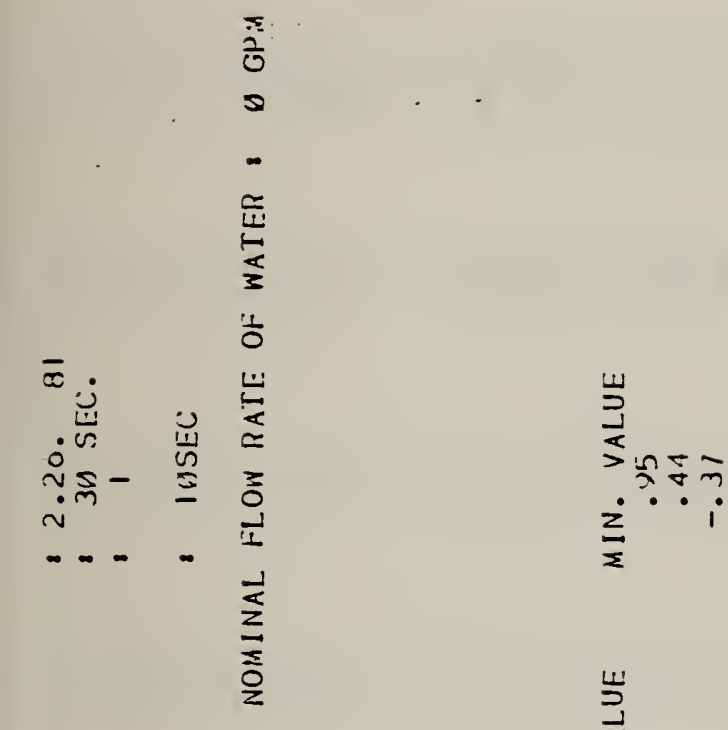

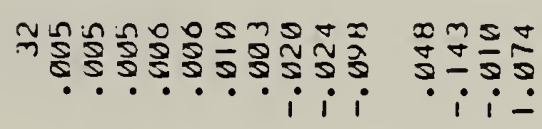

ทักทีกำกับำำ

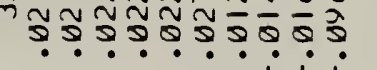

ลิํำก

$\stackrel{i}{0}$

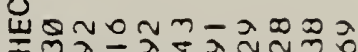

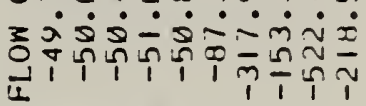

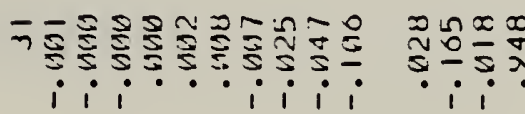

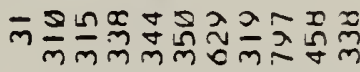

กิริธี้

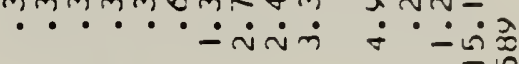

(1)

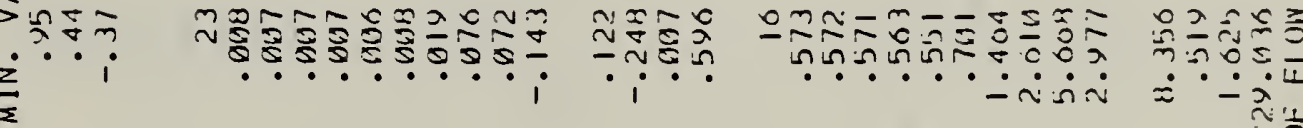

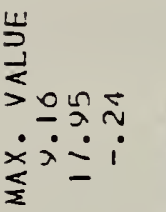

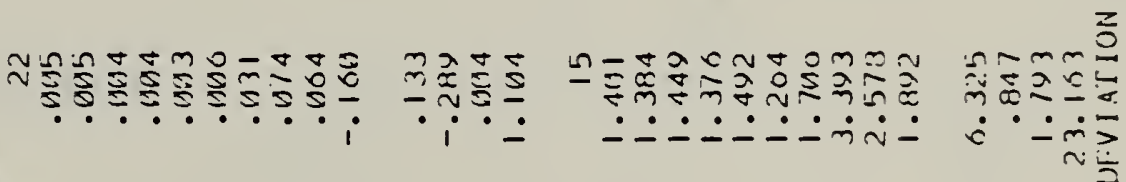
오

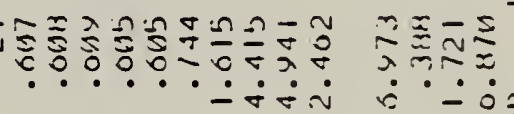

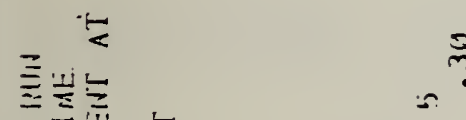

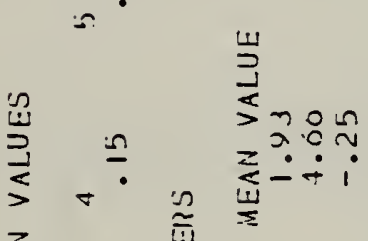

E

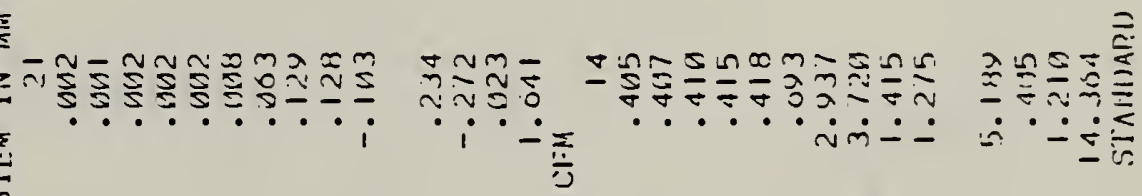

当亲

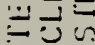

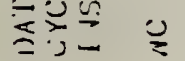

亏ั)

志岕

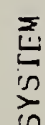

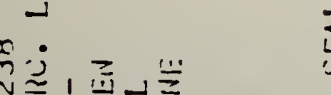

方产全

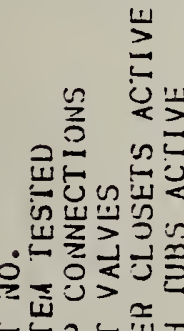
岕出高三

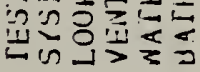

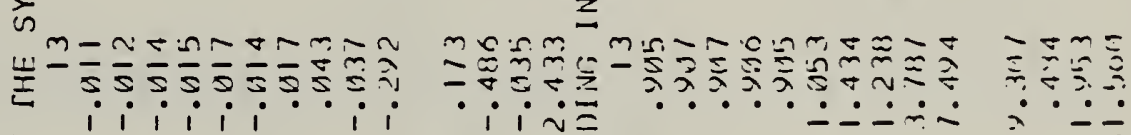
$z$

$\stackrel{\amalg}{\simeq}$

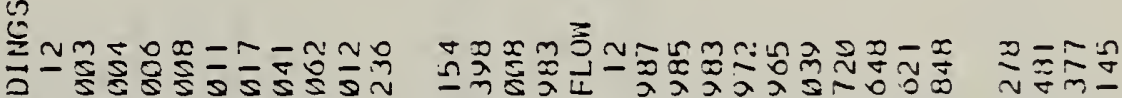
蛋

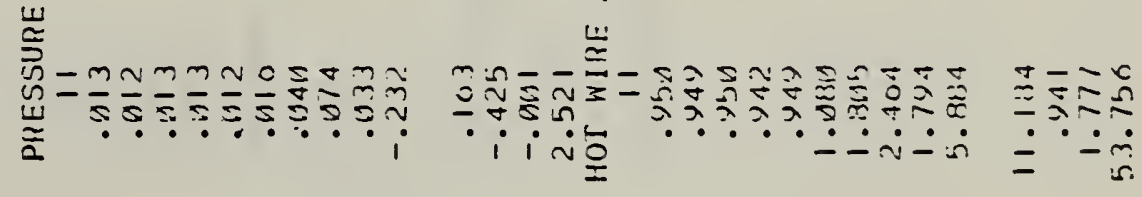

증호
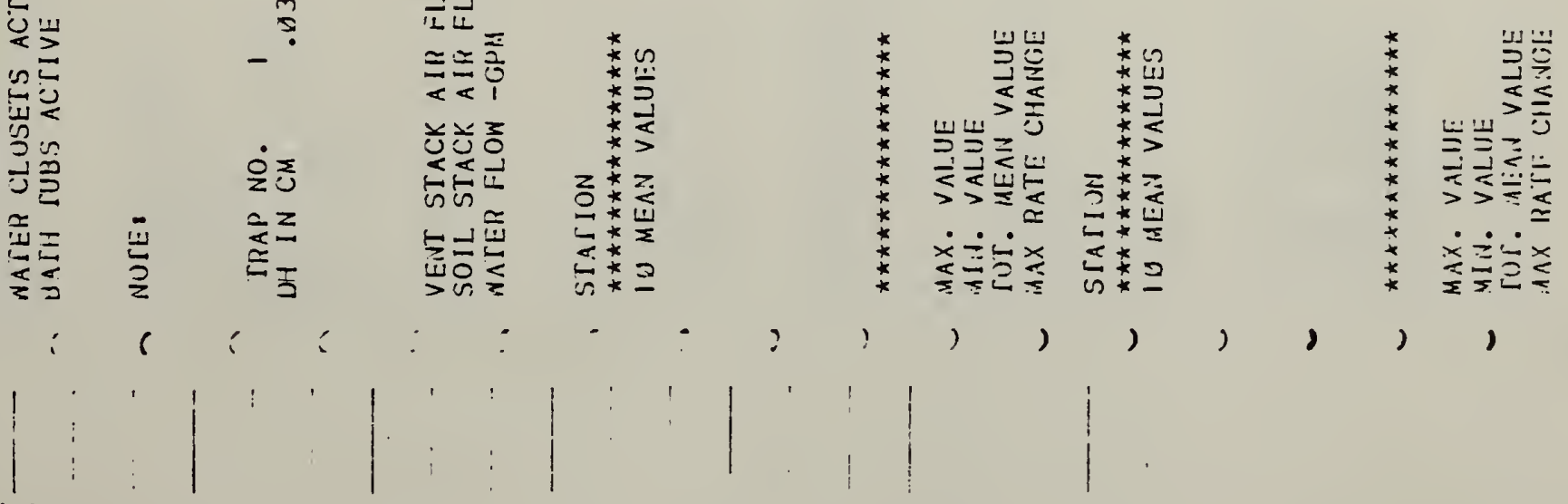


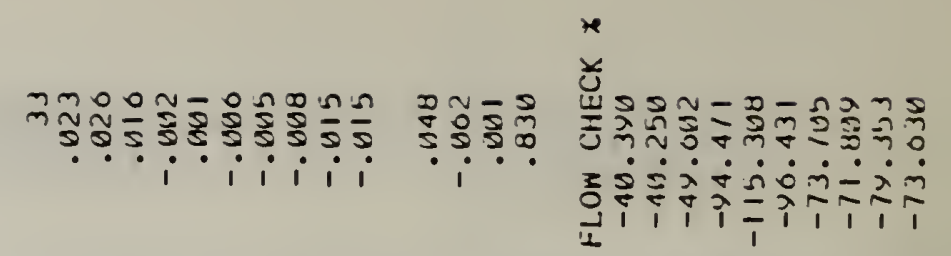

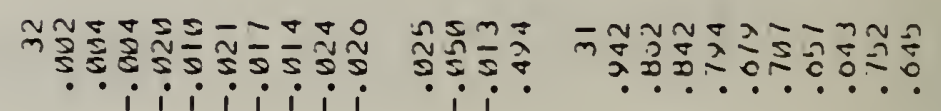

กิำ

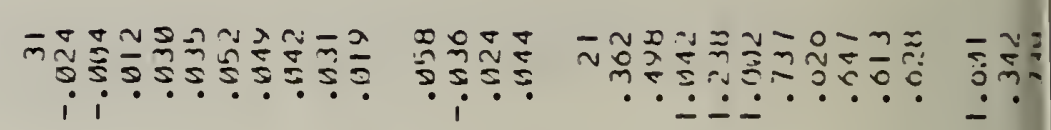

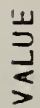

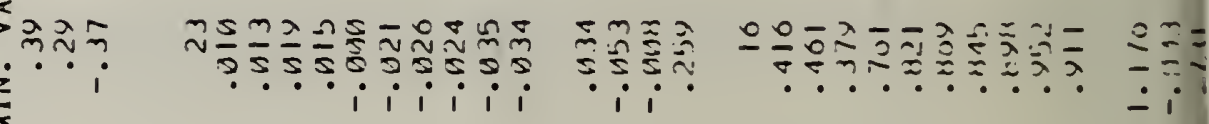

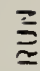

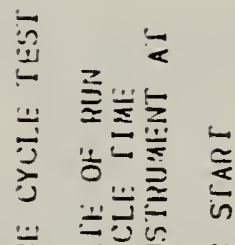

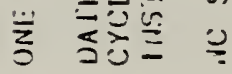

立

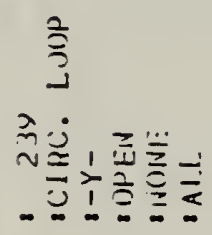

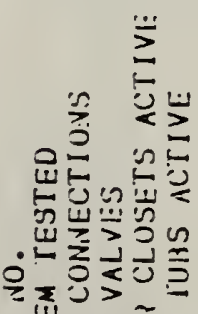

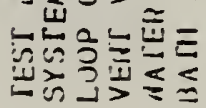

$\sin _{2}^{2}$

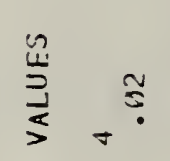

כ

$\frac{\vdots}{\frac{1}{2}}$

宸

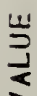

$>m \Xi \simeq$

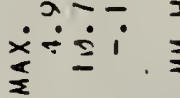

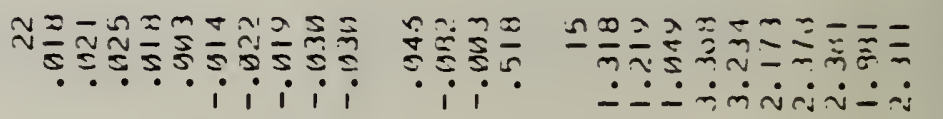
$\stackrel{0}{\underline{1}}$

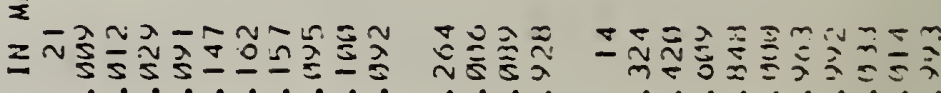

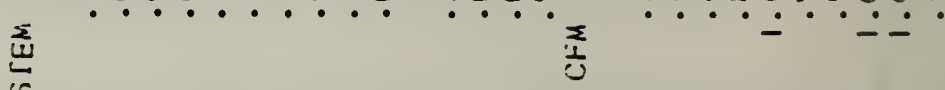

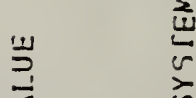

Dึ๊

$\sum_{\Sigma}$

iे

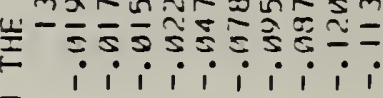

$z$

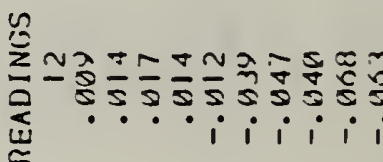

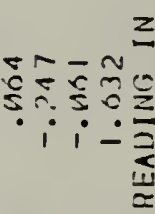

$z$

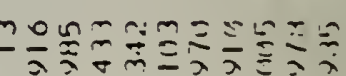

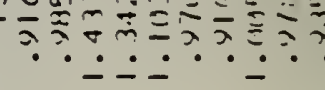

$$
\text { (⿸丆口 }
$$

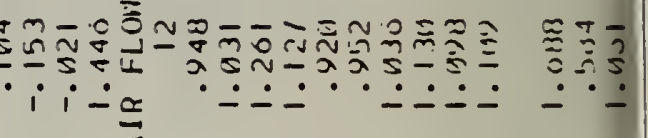

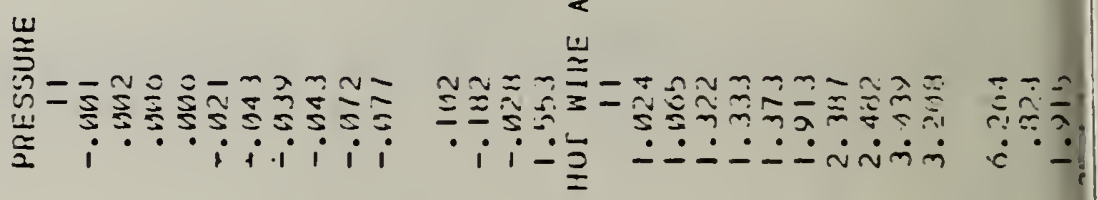

छे

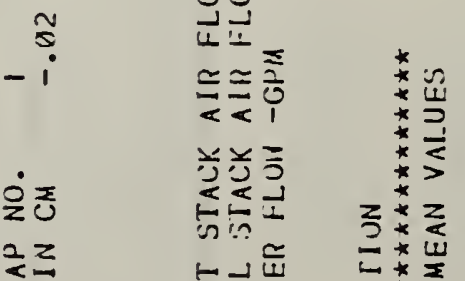

既

总宁岕

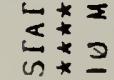

(2) 2

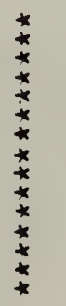

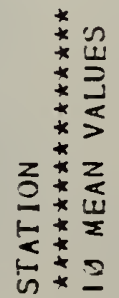




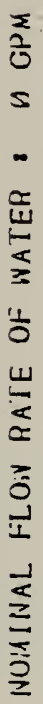

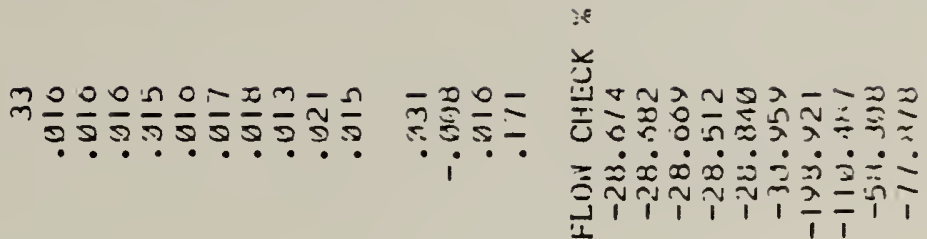

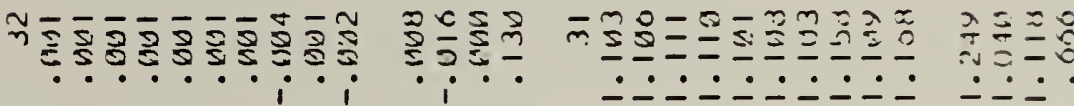

$\div \dot{-} \dot{2}$

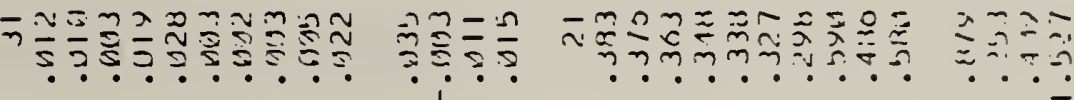

岇

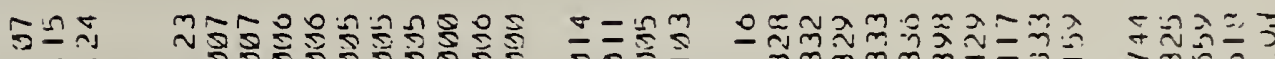
ji.

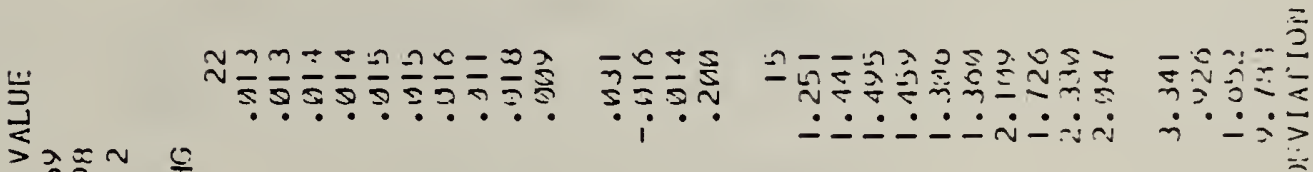

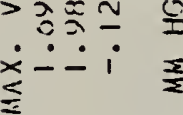

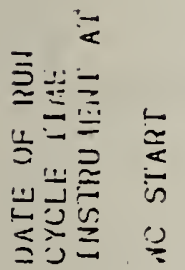

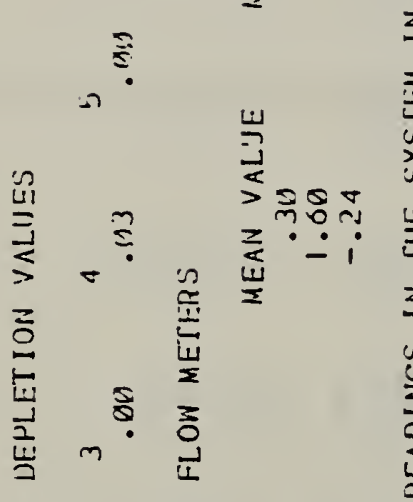

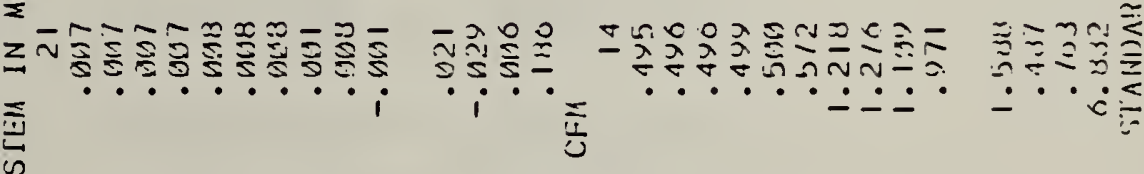

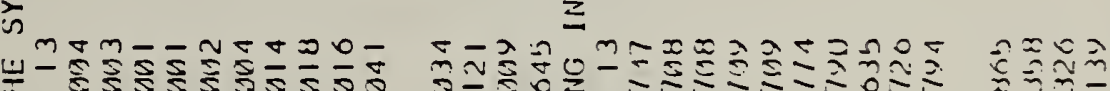

z

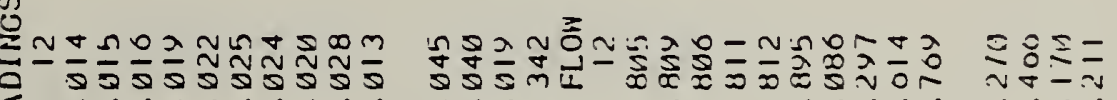

$\stackrel{2}{3}$

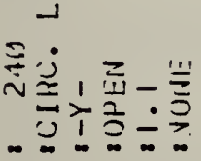

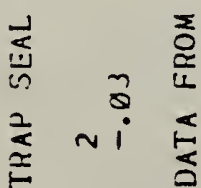

$\underset{\simeq}{\simeq}$

勇突

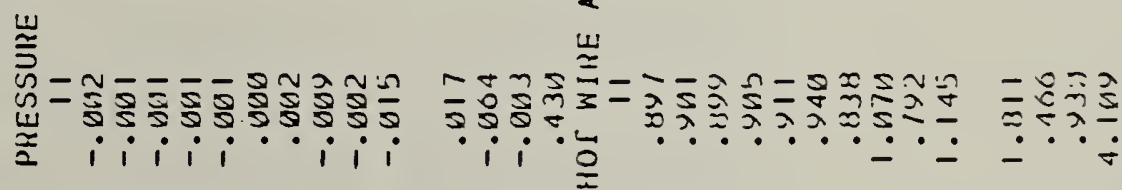

종흠

in

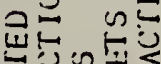

出山

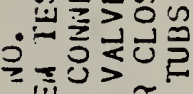

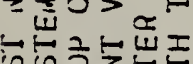

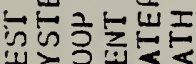

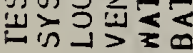

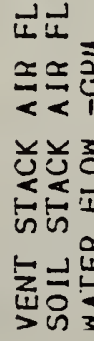
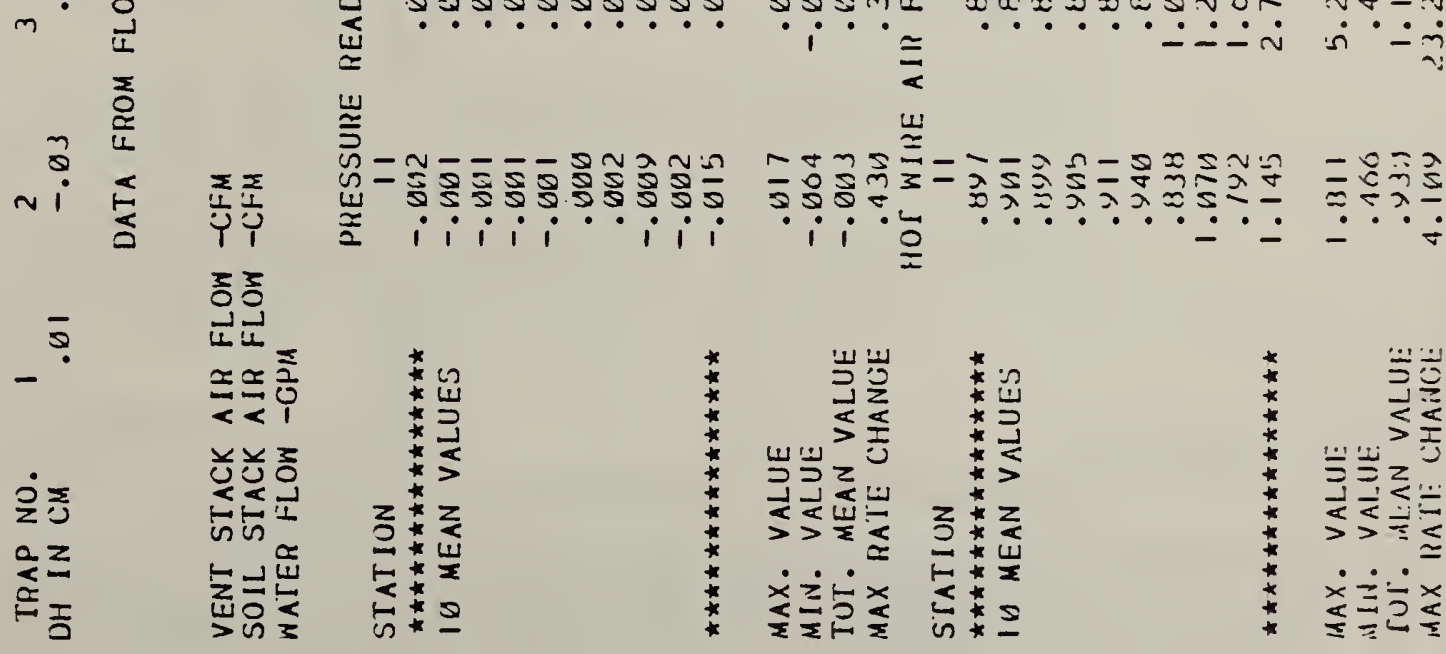
$\dot{\imath} \dot{\dot{n}}$

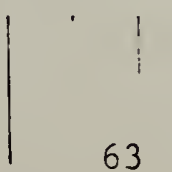


Appendix 2

Comparison of Test Results Among Runs

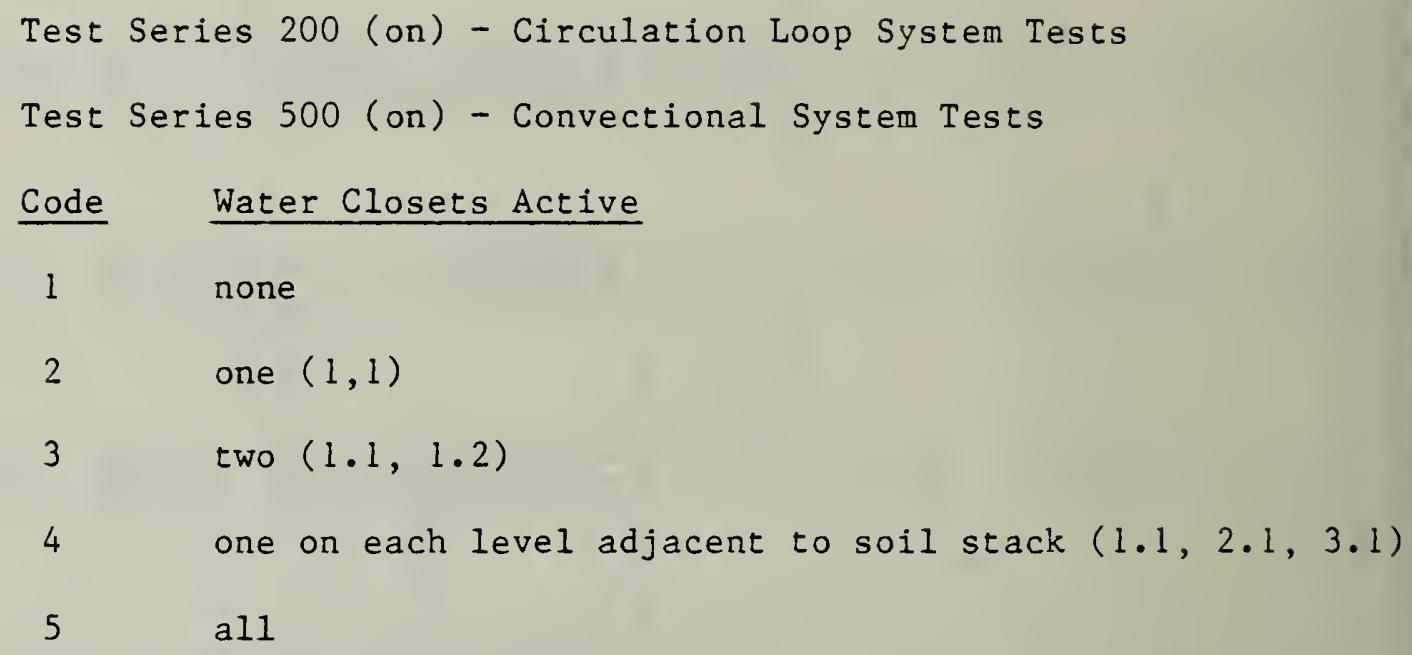




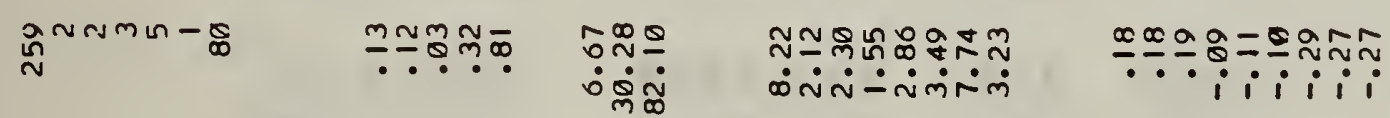

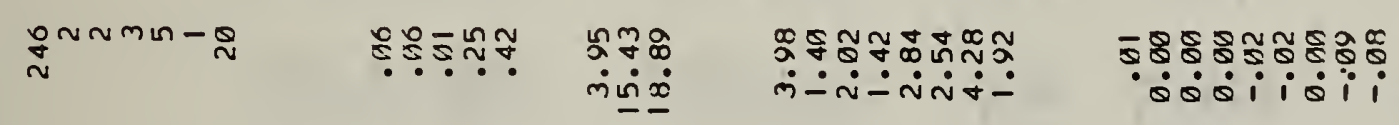

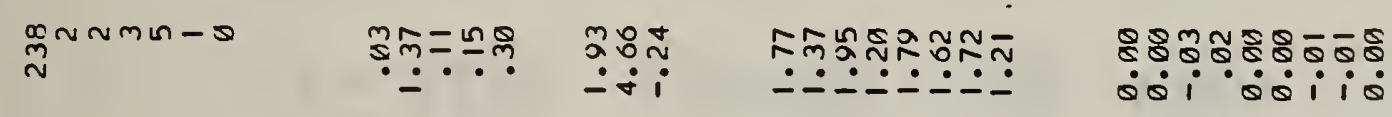

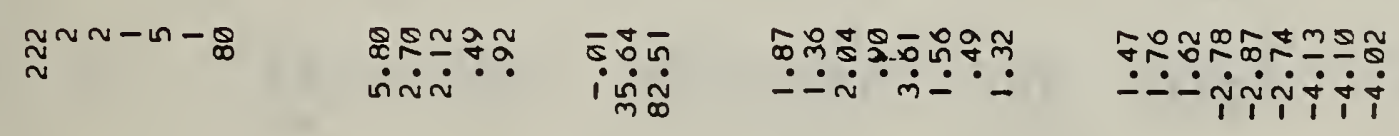

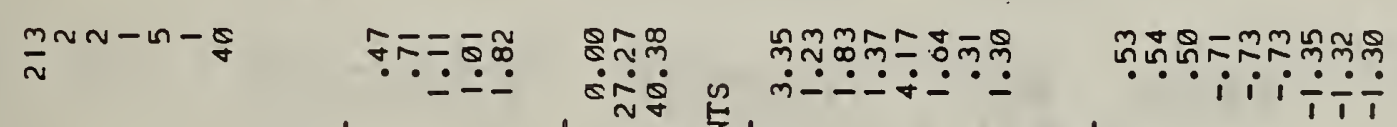

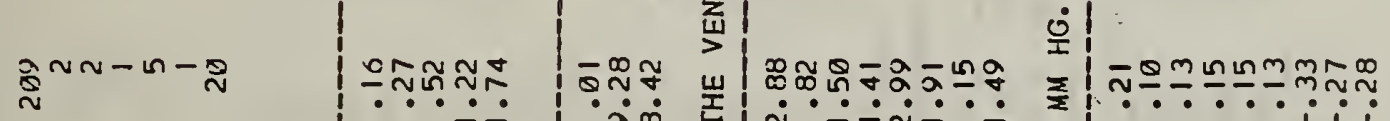

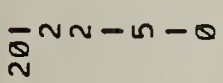

票

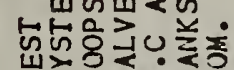

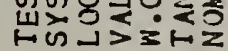

w)

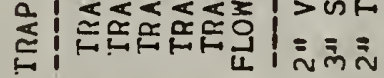

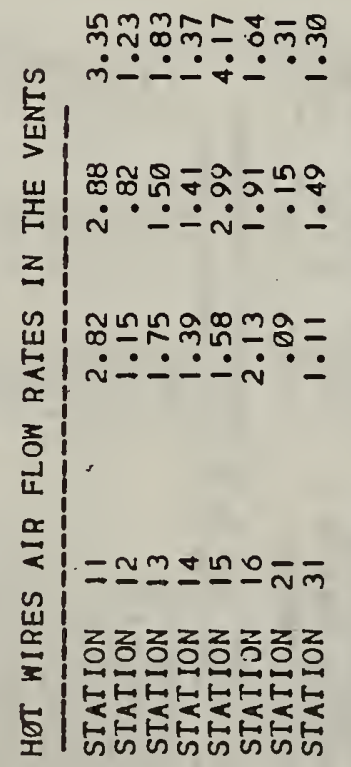

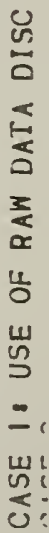



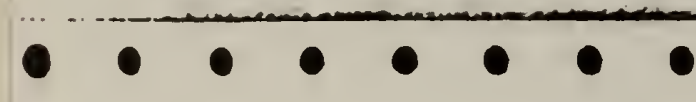

\section{.}

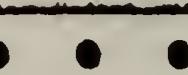

\section{-}

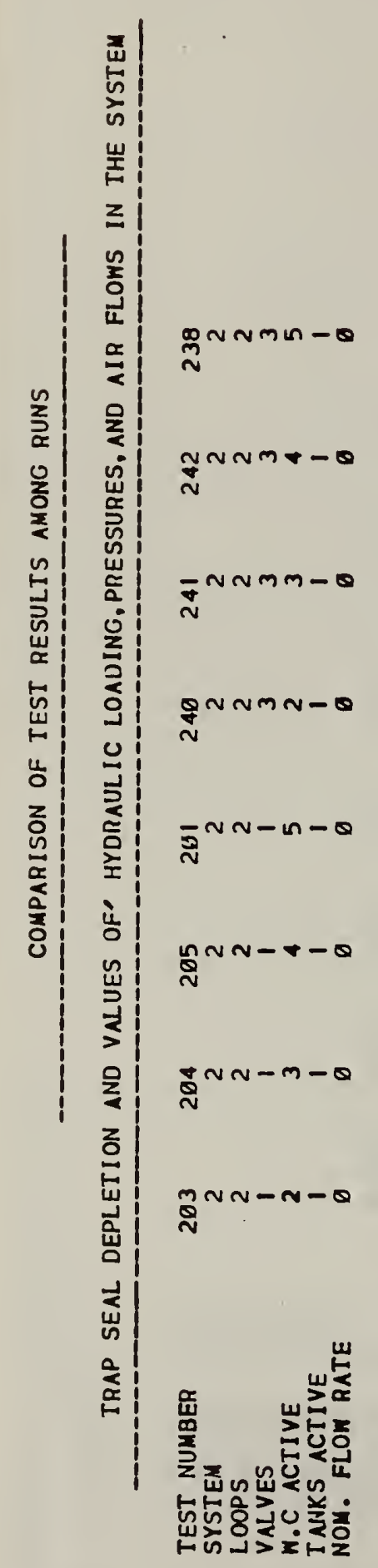

ติตัตำำ

ตุ:

-

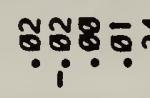

8.88

ละ8\%

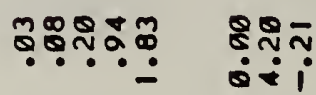

ตุะจำด

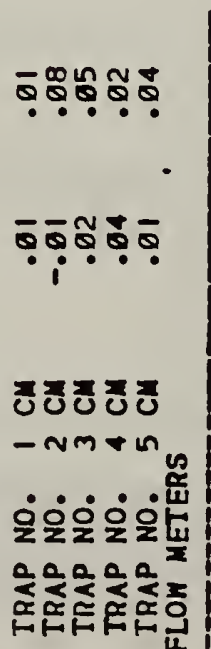

ํำ

㐫i

ติํํำ

ำกำำำำำ

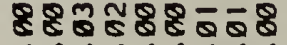

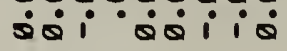

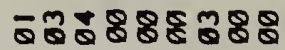 \\ i isisisi}



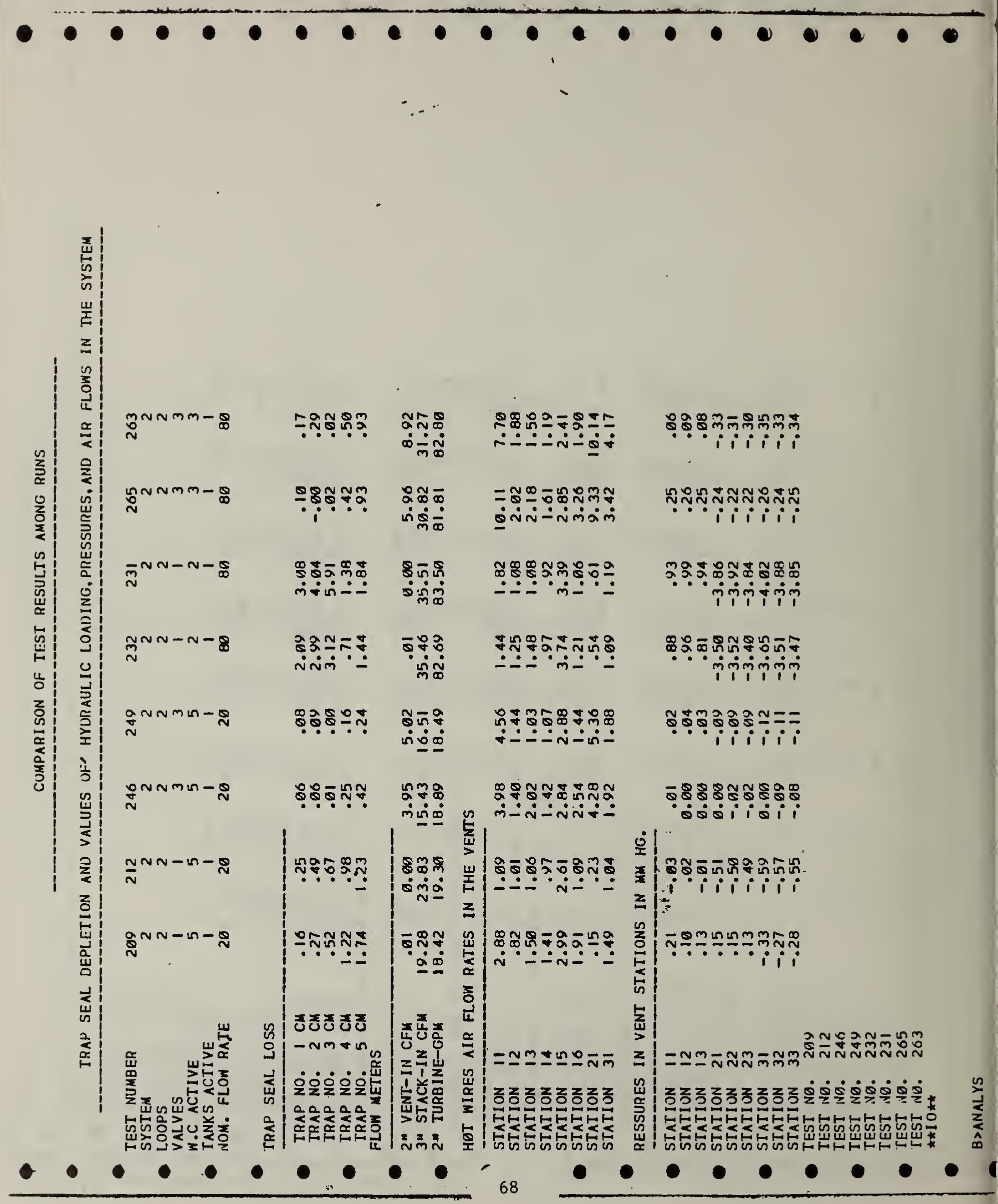

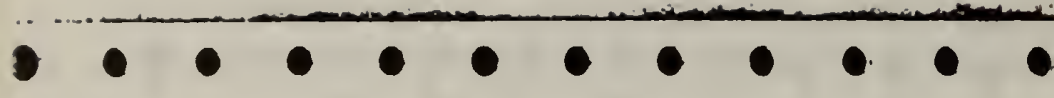


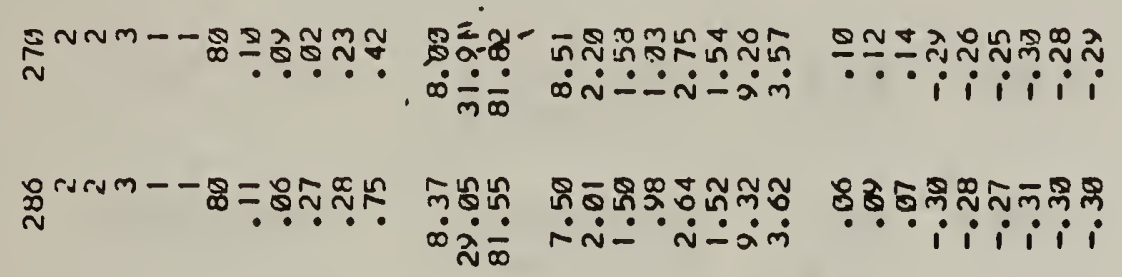

恶

岸

กับ พ - -

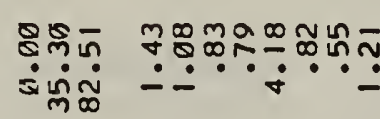

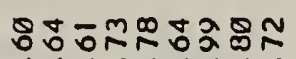

рिंрिंpिं

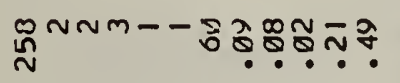

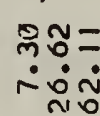

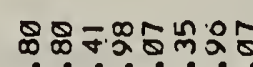

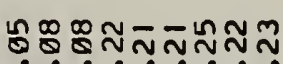

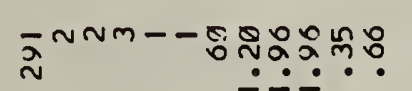

ํㅣㅀำ

กี๊ लं

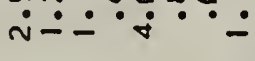

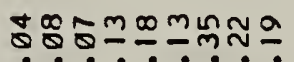
î̃ĩĩ

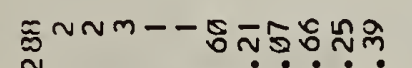

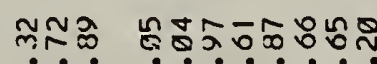

กั்่

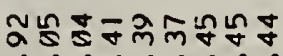

- $i$ ii i

ลัก

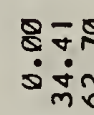

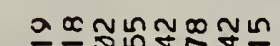

Qนก็นฺ

$\ddot{-} \div \dot{0} \cdot \dot{0}$

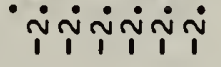

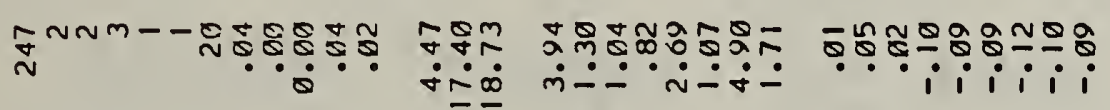

ลัก

-

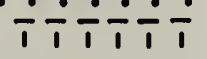

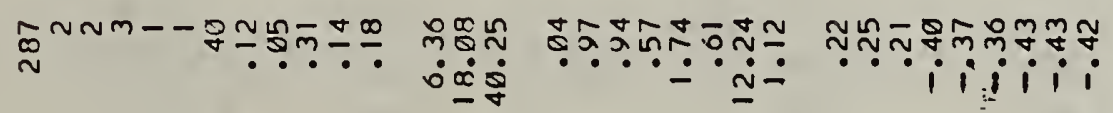

年nn--

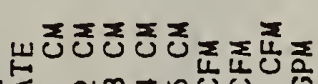

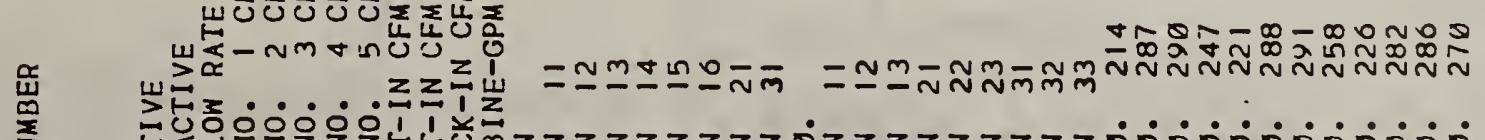

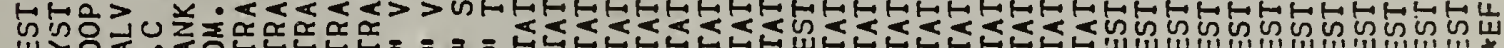

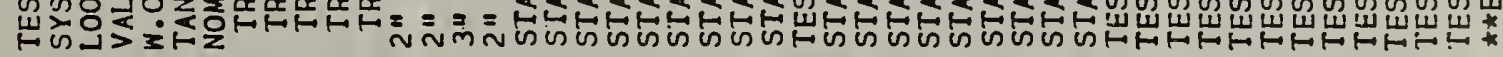




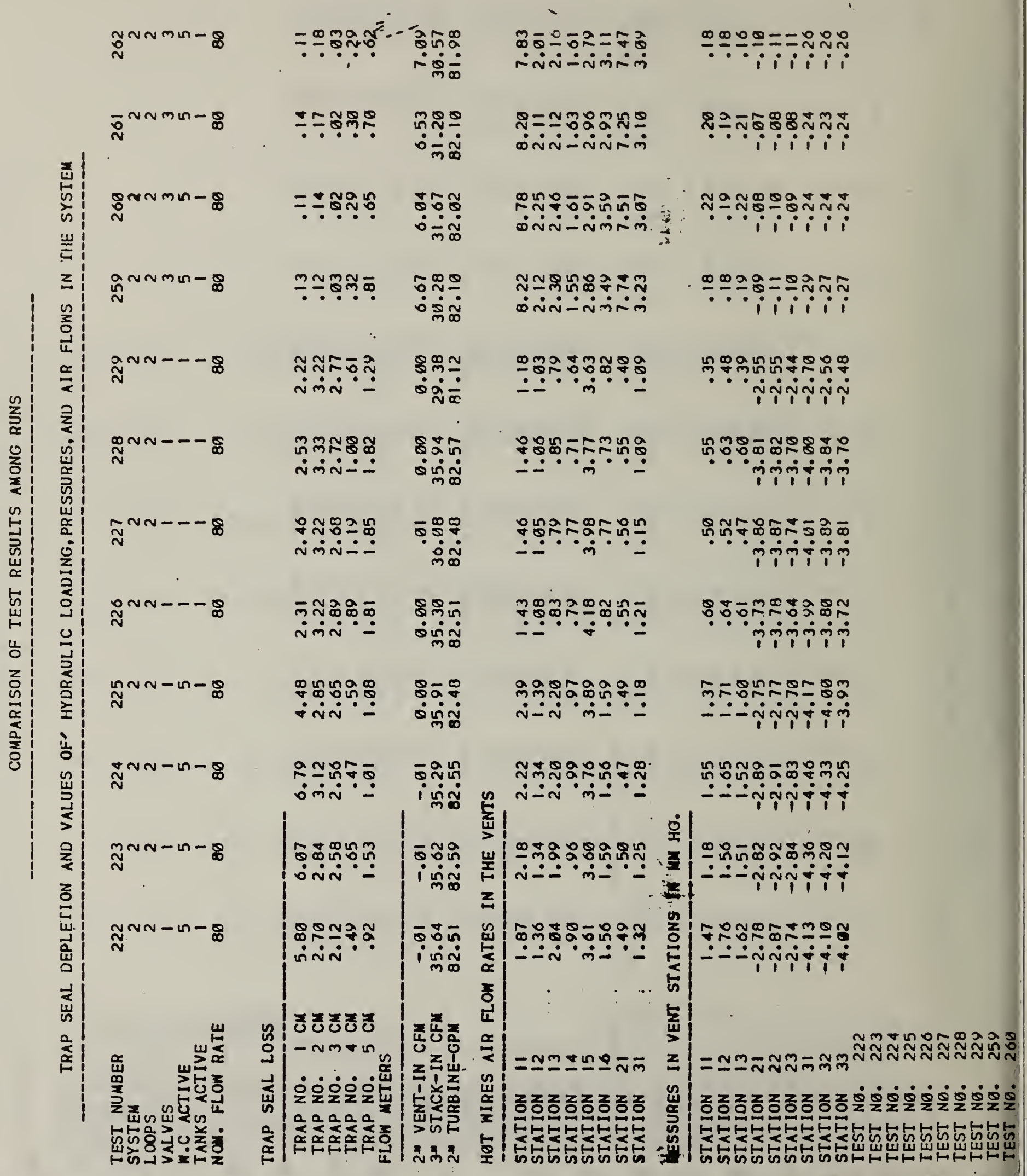




\begin{tabular}{|c|c|c|c|c|}
\hline $\mathscr{N}^{1}$ eunm & =赵 & 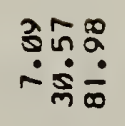 & 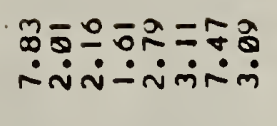 & 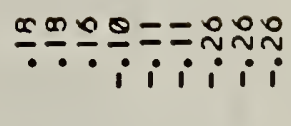 \\
\hline 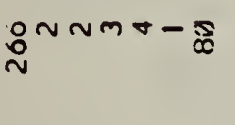 & 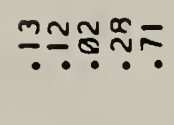 & $\begin{array}{l}\bar{m} \dot{\omega} \overline{0} \\
\dot{0} \dot{m} \bar{\infty}\end{array}$ & 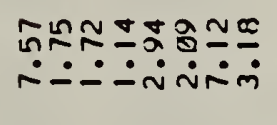 & 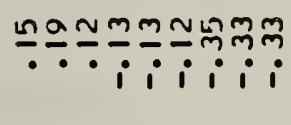 \\
\hline$\stackrel{\text { हn }}{\sim}$ & 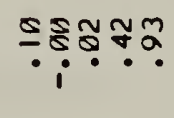 & 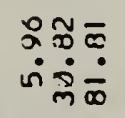 & 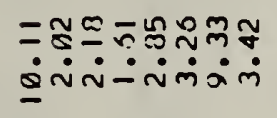 & 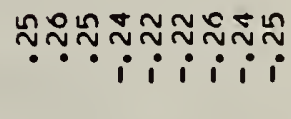 \\
\hline 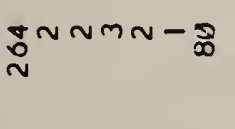 & ニニミッ & 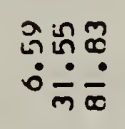 & 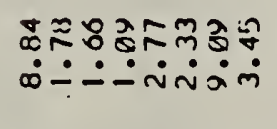 & Nํำกัก๊ \\
\hline$\stackrel{\sim}{\sim} \sim \sim-n-\infty$ & 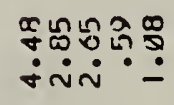 & 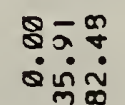 & 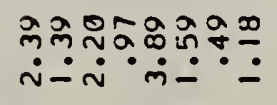 & \\
\hline
\end{tabular}

$\stackrel{\sim}{\sim} \sim \sim-\nabla-8$

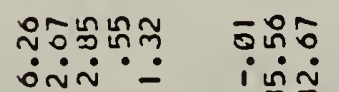

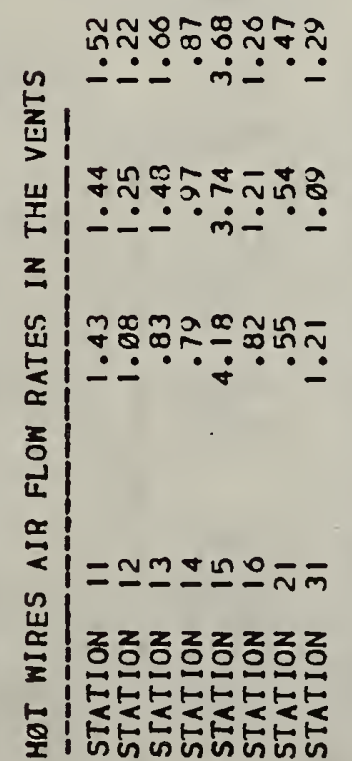

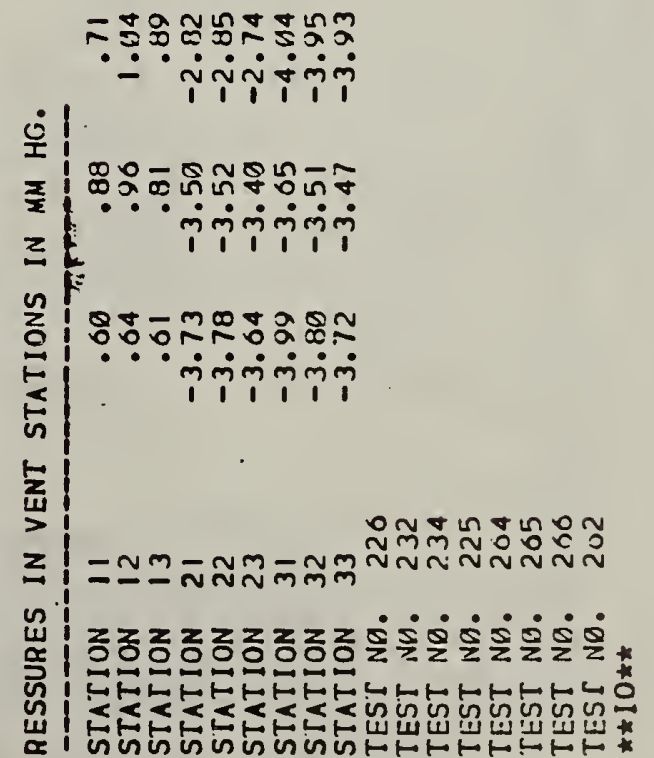




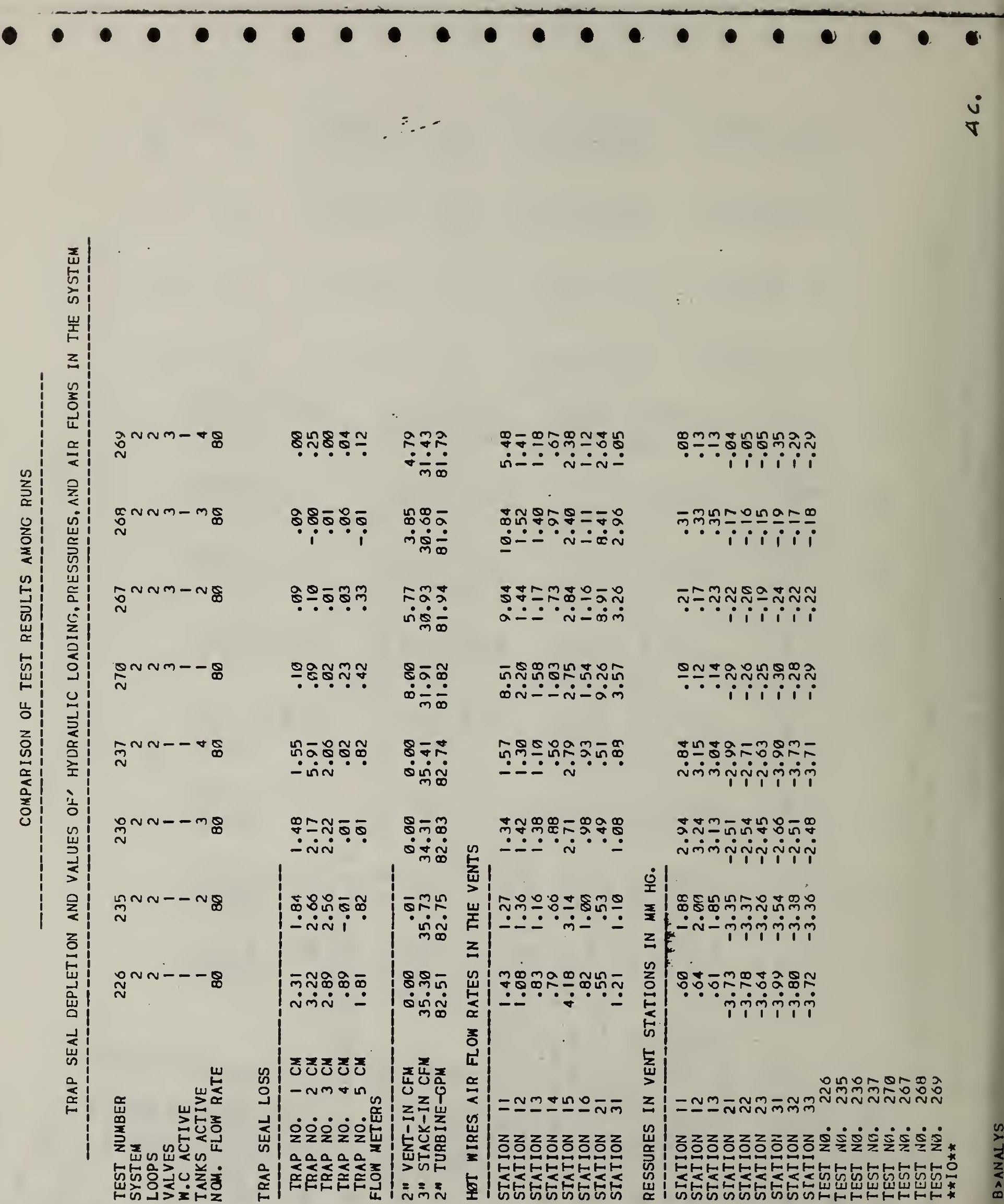




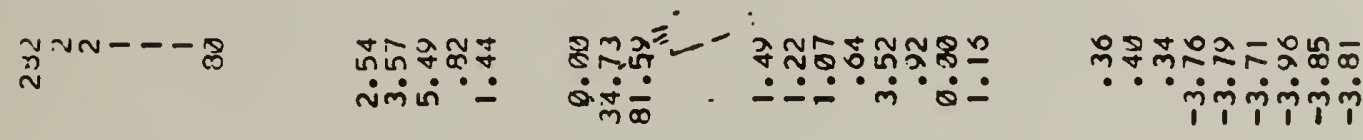

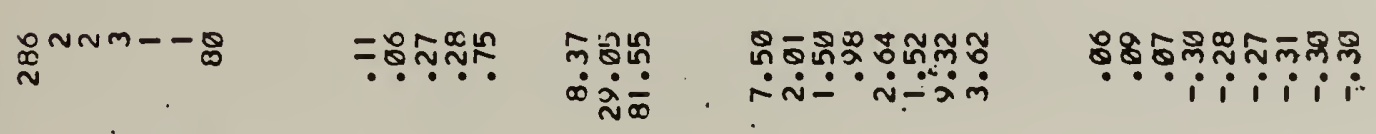

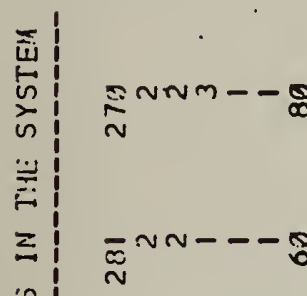

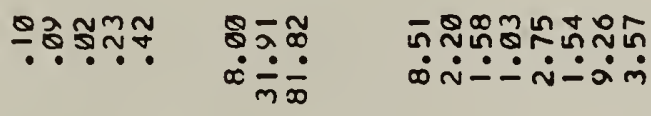

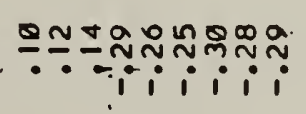

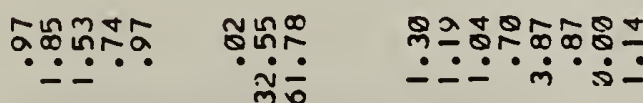

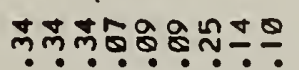

$$
\text { îiNiNíi }
$$

$$
\text { ڤ }
$$

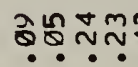

กับส

จํํำ

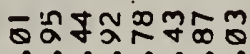
푸숭

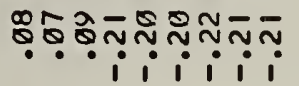

$$
\stackrel{n}{\sim} \text { rinm- - }
$$

ลำำกั

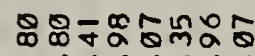

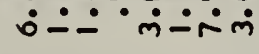

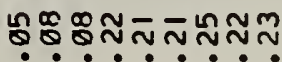

$\because i_{i} i_{i}$

$$
\overline{\tilde{D}}^{N} N---q
$$

รักำรัติ

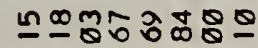

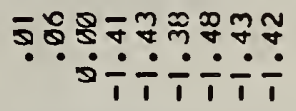

$\stackrel{\sim}{\sim}$ NNm--

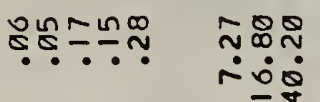

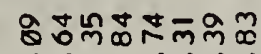

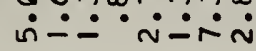

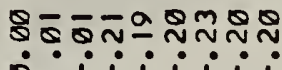

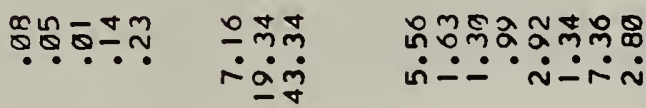

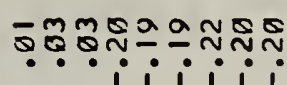

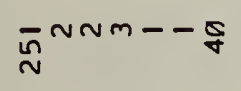$$
\text { rám }
$$

$\frac{n}{2} \sim n--\frac{n}{n}$

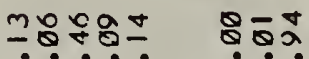

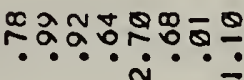
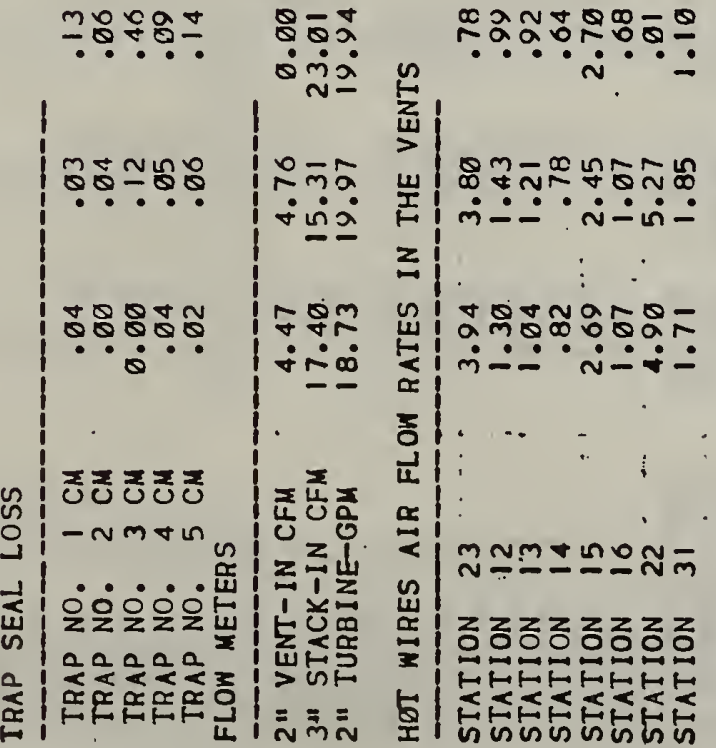

$\dot{8}$

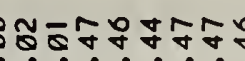

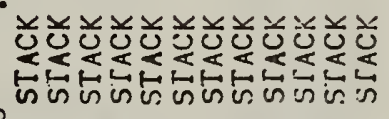

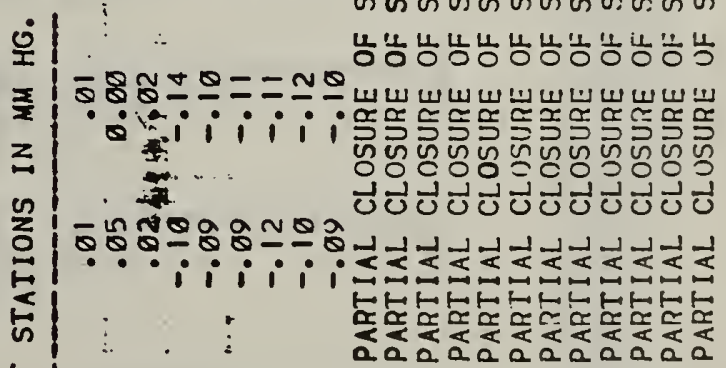

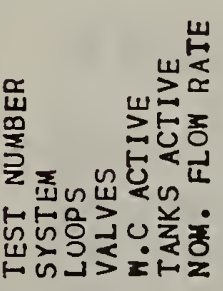

密

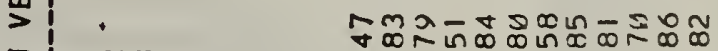

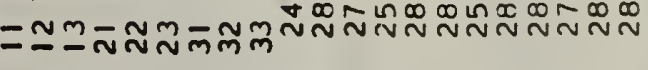

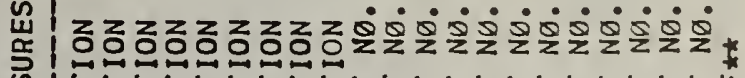

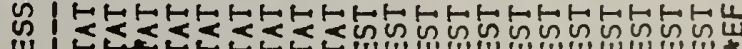
出 
กัก

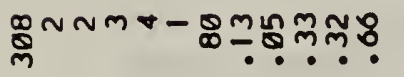

กี้

ถัก พ

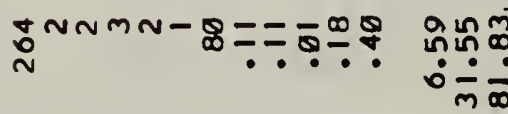

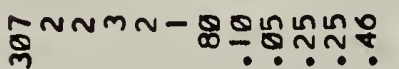

จิกีุ

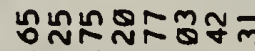

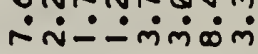

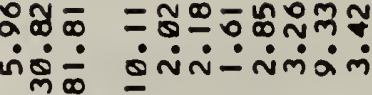

ลำก

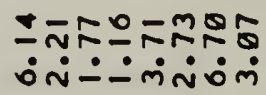

ำตำ

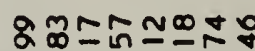
ஸ் $\dot{\sim} \dot{m} \dot{m} \dot{\sim}$

กํํีกำกำก

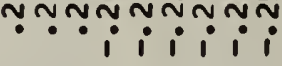

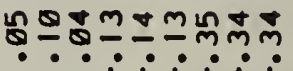

-. i i i i

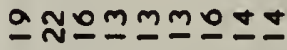

- $i$ i i

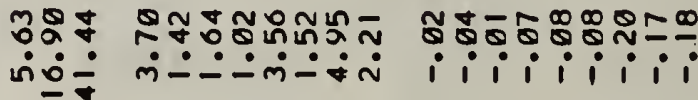

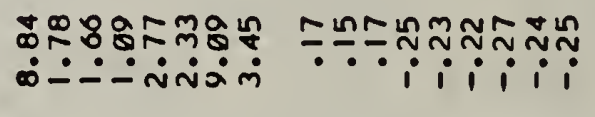

กูก

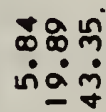

$\underline{m} \frac{0}{8} 8 \bar{m} \bar{m}$

ஸ்-ெंn்ं

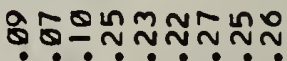

- i i i i

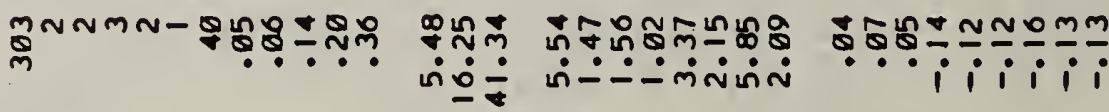

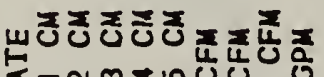

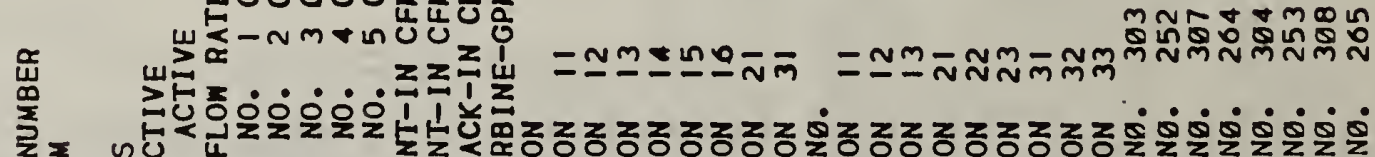

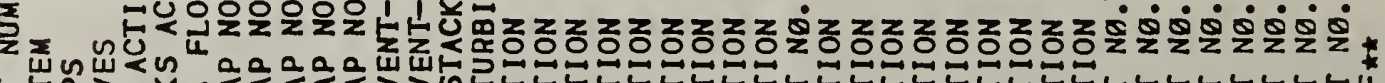

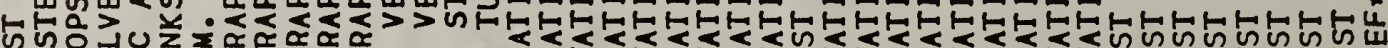

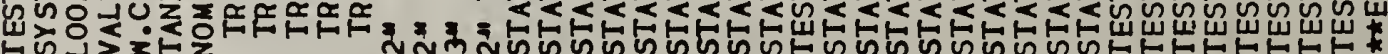




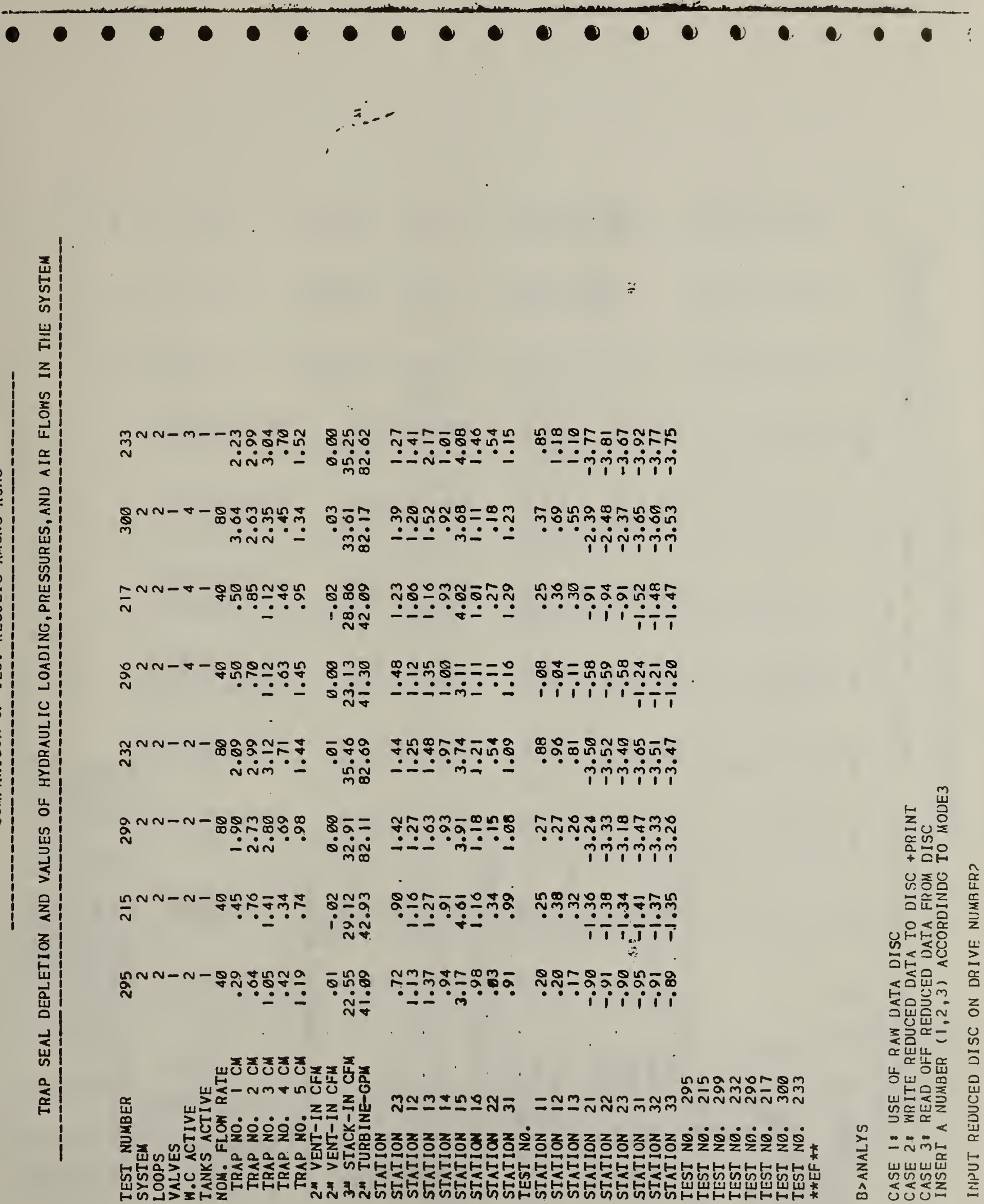




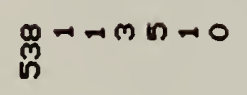

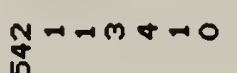

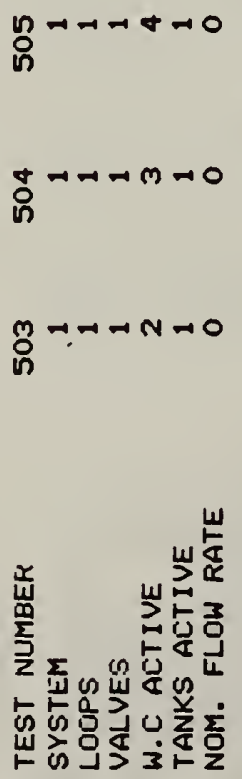

i⿱宀

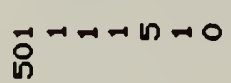

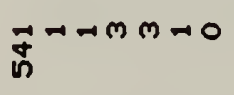

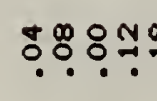

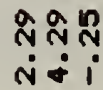

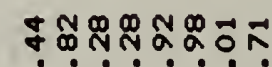

ํํำ

ํํำำกำ

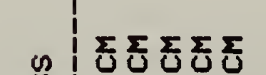

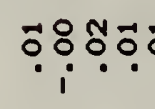

ทีตักำ

ใำ.ำ

$\left|\begin{array}{|l|}\mid \\ \hline\end{array}\right|$

ลั่ं

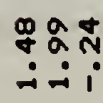

ลิ่า

วิำำ

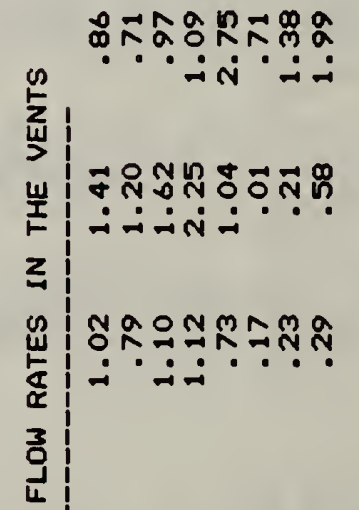

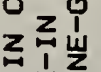

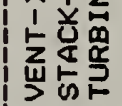

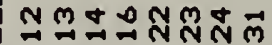

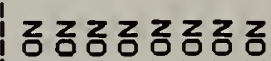

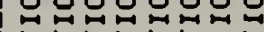

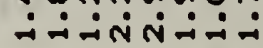

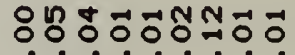

०i i i i

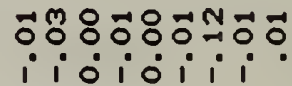

둥ํㅇ융ํำ

i i 100000

ㅁํํํํํㅇํำ i० i० $000^{\circ}$

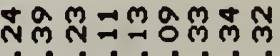

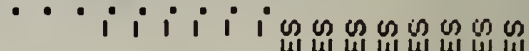

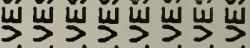

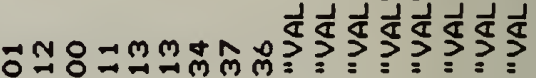
- 0 i i i

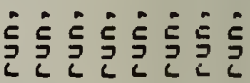

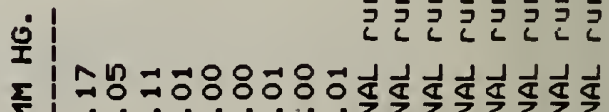

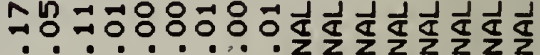
z i i ióio

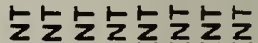

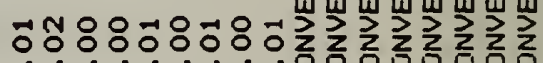

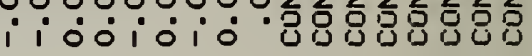

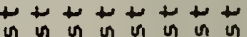

in in in in un in $n$ in

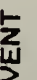

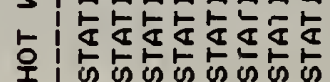

$m+u=0$ m z|

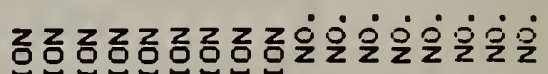

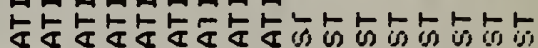

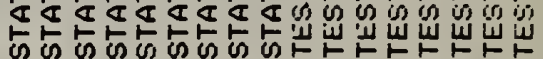




$$
\begin{aligned}
& \text { เุ๋ } \\
& \text { 吕ヘーMロー웅 }
\end{aligned}
$$

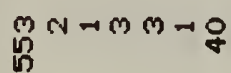

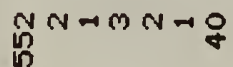

$$
\text { मूึก }
$$

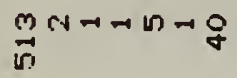

คิ่

$\min 2 n+m-8$

מnd

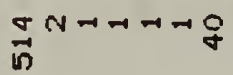

空

它

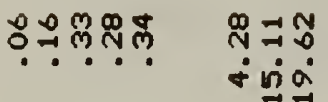

듬 Mํํำ웅

बุำตำ

ๆติกักิ

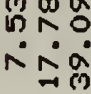

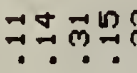

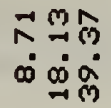

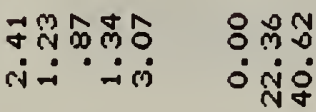

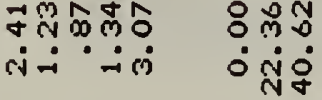

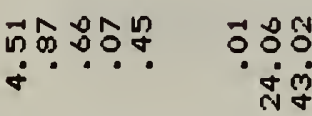

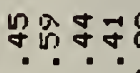

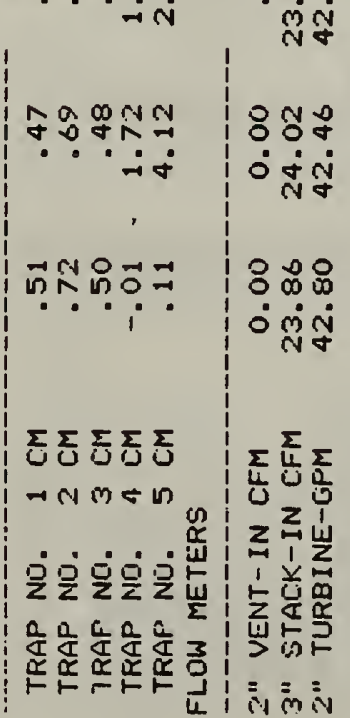

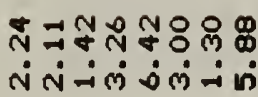

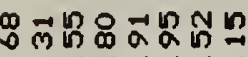

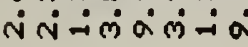

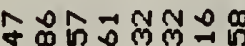

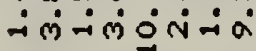

ูำ

संनित्रतनं

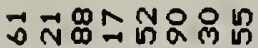

$\because-\mathrm{N}^{2} \mathrm{~N}-\mathrm{O}$

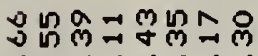

नंसंस्तं लं

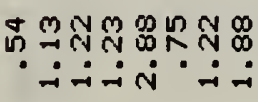

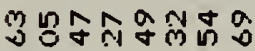

तनinन.

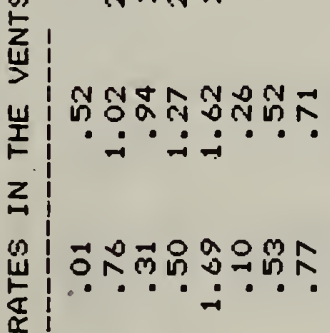

亏亏

茨

$\stackrel{\infty}{\square}$

裉

즘즈으므믐

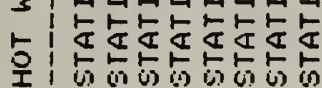

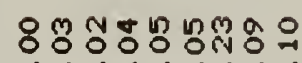

$\circ i i i_{i} i i$

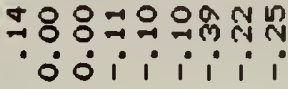

ํํำํํㅇํำำก

$i$ i i i i i

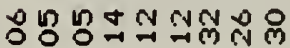

$i i i i i i i$

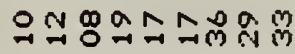
i i i i i i

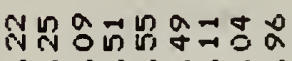

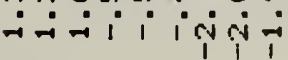

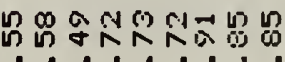
? ११क्ष

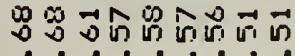
14i \begin{tabular}{l|l} 
Pon \\
z
\end{tabular} 


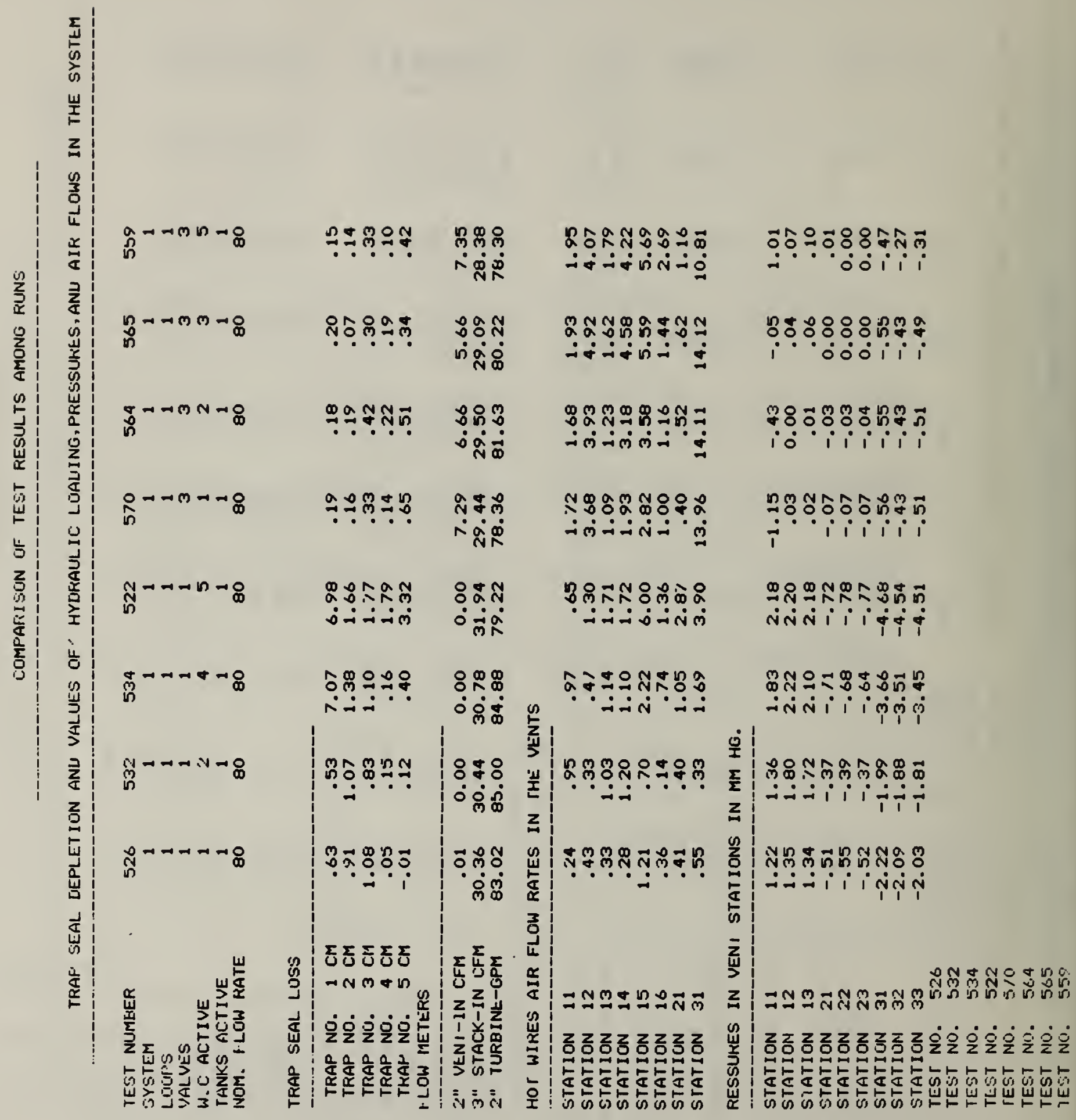




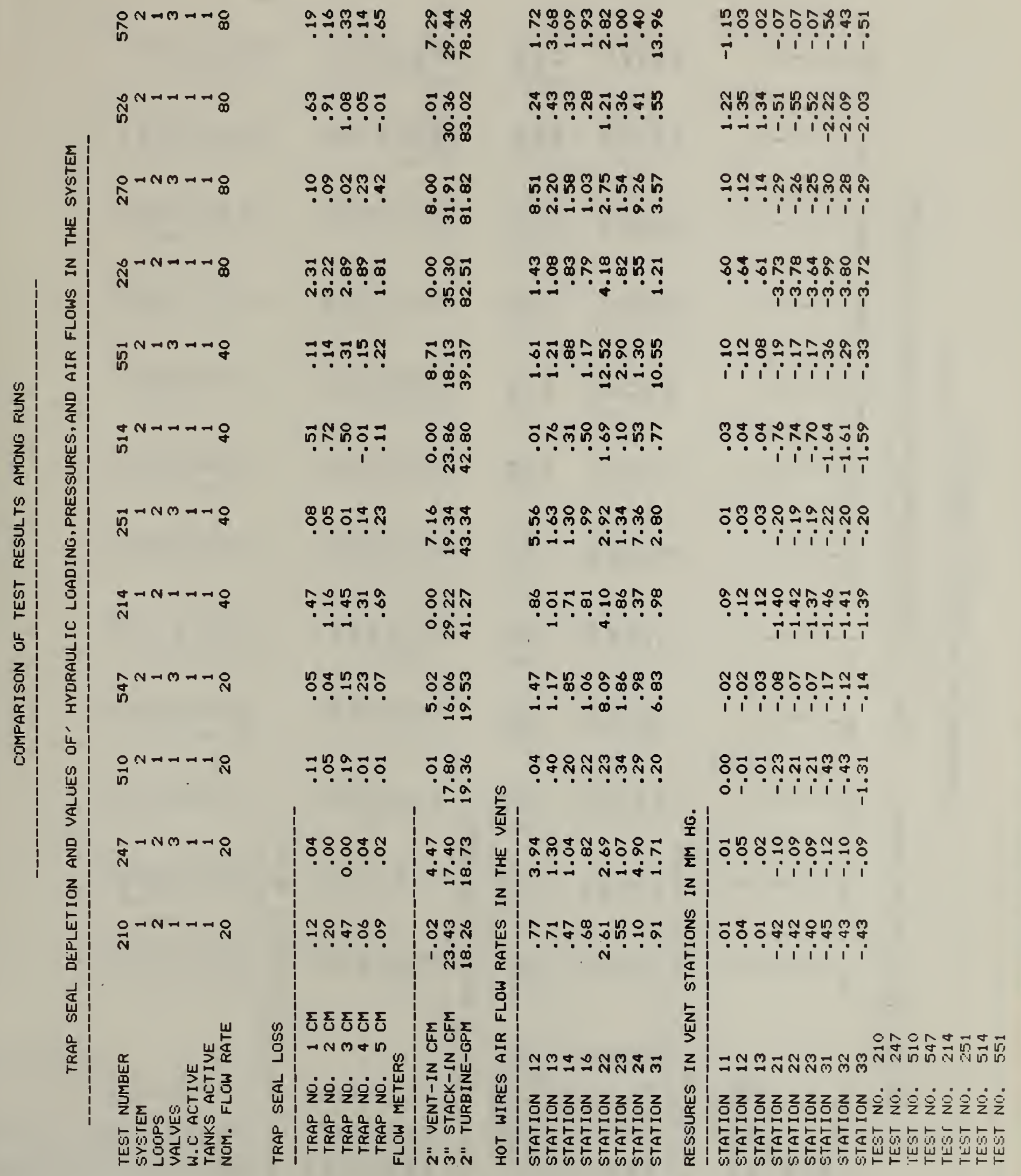




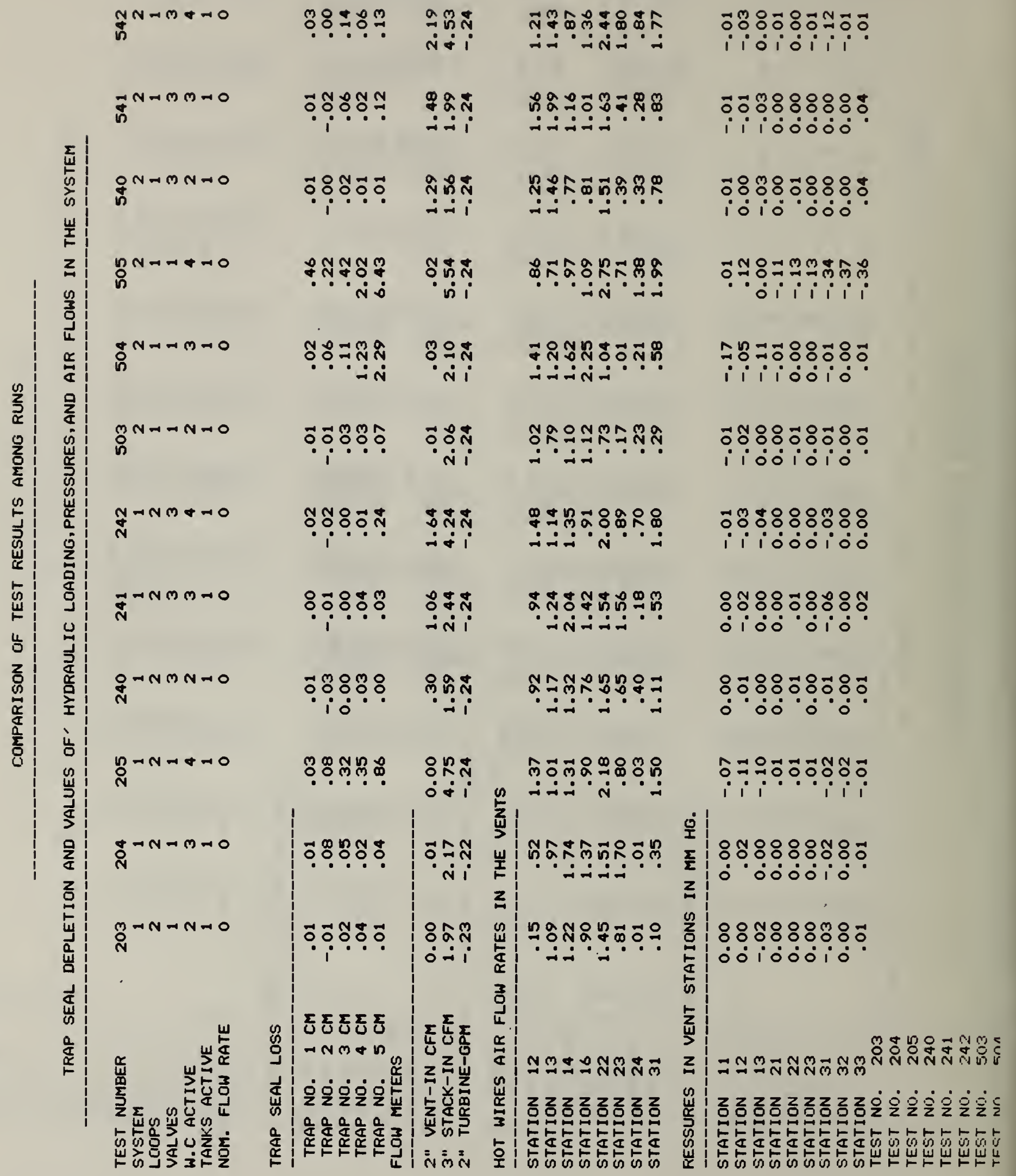




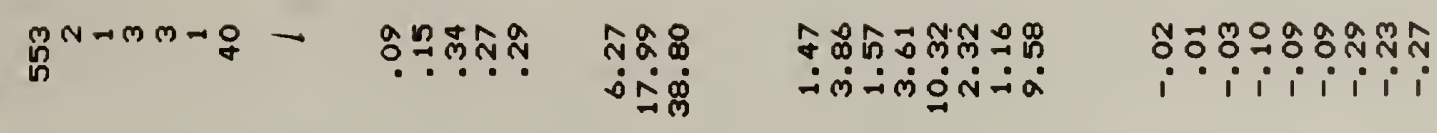

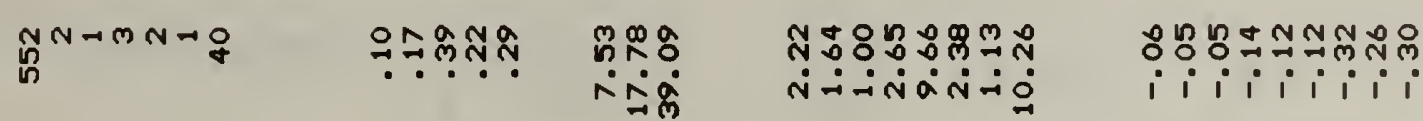

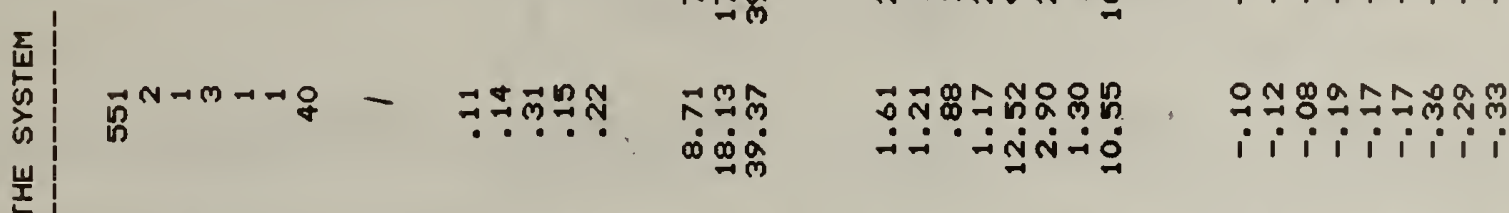

$$
\begin{aligned}
& \text { मี }
\end{aligned}
$$

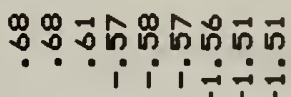

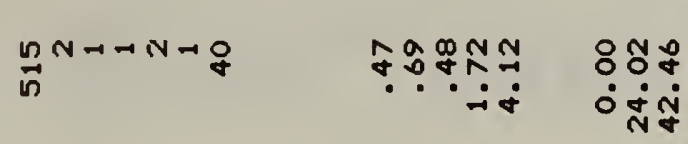

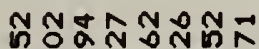

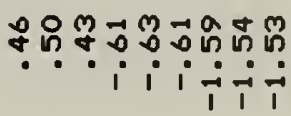

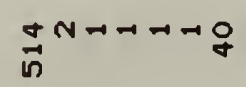

เกำดี

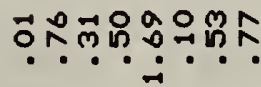

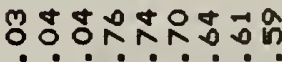

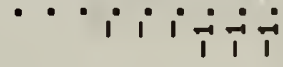

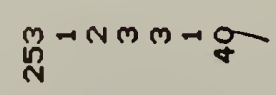

ํํํํำำ

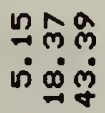

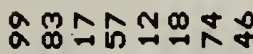
तिस्तलिखंड

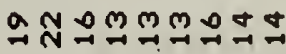
$\because \mathbb{i} ; i ; i$

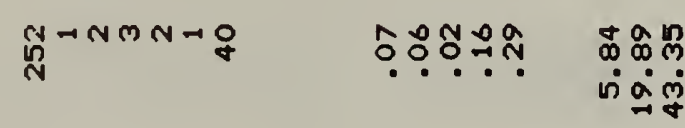

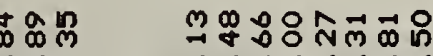

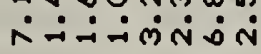

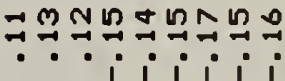

$$
\vec{n}^{-N M n-R-~}
$$

ํำำำำ

롤

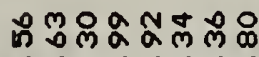

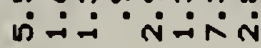

อำำำำกำำ

$$
\frac{4}{b-n \rightarrow m-d}
$$

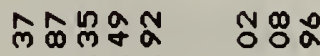

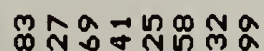

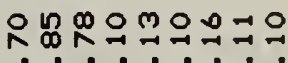

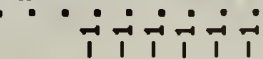

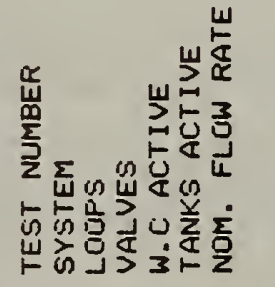

$$
\underset{A}{A} \rightarrow n \rightarrow A-Q
$$

霖 $\underset{\frac{a}{a}}{\frac{a}{a}}$ $\frac{4}{n \rightarrow n \rightarrow n \rightarrow d}$ กิ่สู

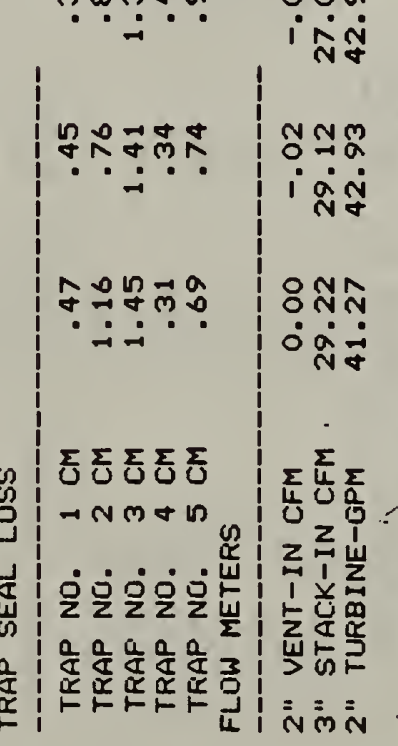

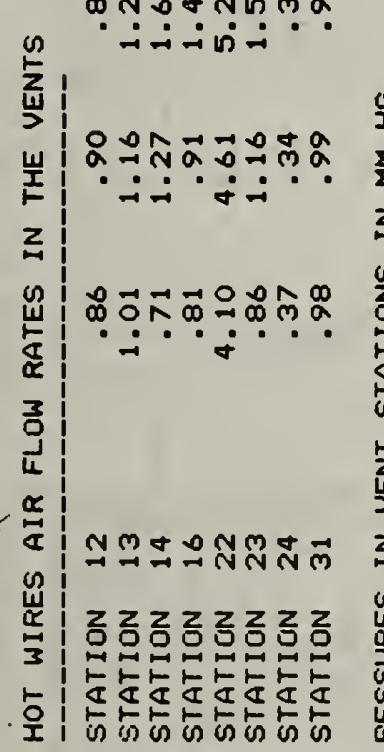

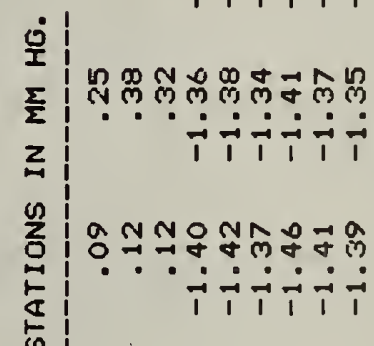

$\sum_{\text {岀 }}^{5}$

$\int_{1}$

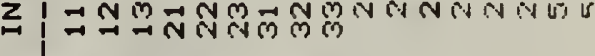

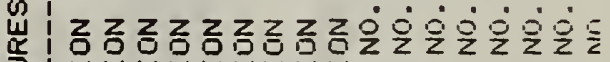

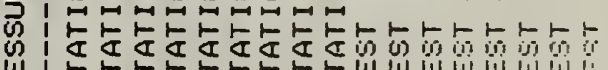




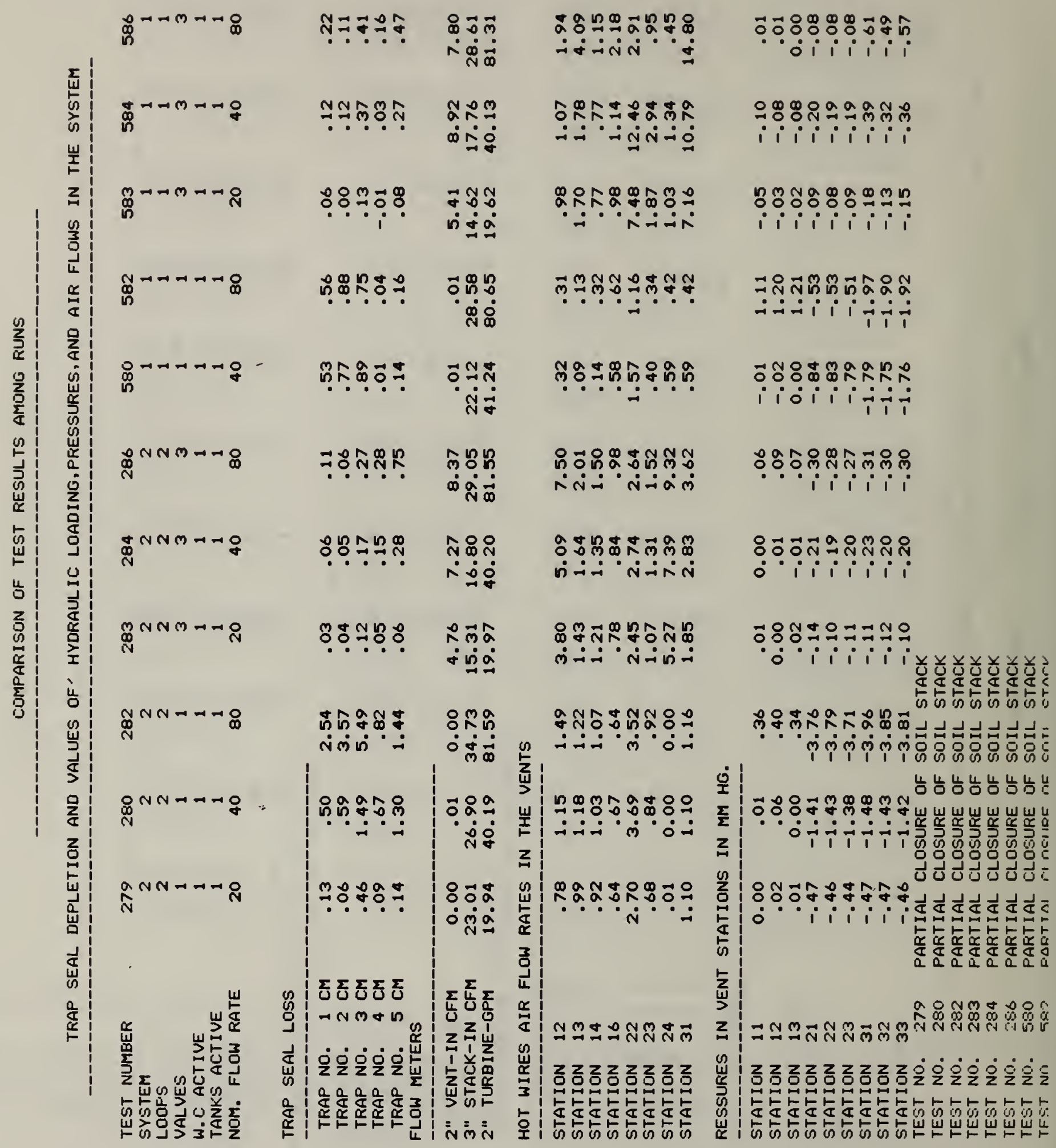


NBS-114A (REV. 2-8C)

U.S. DEPT. OF COMM.

BIBLIOGRAPHIC DATA

SHEET (See instructions)

1. PUBLICATION OR

REPORT NO.

NBSIR 82-2602

2. Performing Organ. Report No. 3. Publication Date

December 1982

4. TITLE AND SUBTITLE

EXPERIMENTAL EVALUATION OF CIRCULATION LOOP DRAIN AND VENT PLUMBING MODIFICATIONS FOR BUILDING REHABILITATION

5. $A \cup T H O R(S)$

Fred Winter and Lawrence Galowin

6. PERFORMING ORGANIZATION (If jolnt or other than NBS, see instructions)

NATIONAL BUREAU OF STANDARDS

DEPARTMENT OF COMMERCE

WASHINGTON, D.C. 20234

7. ContracuGrant No.

8. Type of Report \& Period Covered

9. SPONSORING ORGANIZATION NAME AND COMPLETE ADDRESS (Street, City, Stote, ZIP)

10. SUPPLEMENTARY NOTES

[Document describes a computer program; SF-185, FIPS Software Summary, is attached.

11. ABSTRACT (A 200-word or less foctual summory of most significant informotion. If document includes a significant bibliogrophy or literoture survey, mention it here)

Rehabilitation or modernization of existing buildings frequently imposes increased

loads on the plumbing water supply and drainage system. The requirement for venting

in U.S. practice is intended to prevent trap seal loss from exceeding values pres-

cribed in model plumbing codes. The vent piping in older buildings may be marginal

for retrofit under code requirements for new construction with the same or increased

numbers of fixtures and devices installed into the plumbing system.

An experimental laboratory investigation of a "circulation loop" modification to a drain-waste-vent (DWV) system was conducted to determine the change in performance. An experimental evaluation of the performance of the modified system and a conventional system were undertaken for a variety of simulated wastewater-loads with various plumbing fixtures and multi-story soil stack loads. The performance parameters considered were trap seal failures, backflow, and the siphonic action of the water closets. Also, the dynamic responses to pressure excursions and air flow rates in the branches were measured. Both systems were tested to the limiting condition for single-stack performance over a range of air flow rates into the soil and vent stack.

The circulation loop system was found to decrease the pressure difference in the upper a portion of the soil stack, and to provide limited benefits in reducing trap seal failures and fallure due to reduced siphonic action in the lower level water closets. With vent valves open, both the conventional and modified loop systems provided satisfactory venting except at the highest loads. Additional research should be undertaken to develop methods for sizing the soil stack and vent connection fitting connection to the circulation loop. Further testing should also be done with small regulated air flows into the vent stack.

12. KEY WORDS (Six to twelve entries; alphobetical order; copitolize only proper nomes; ond seporate key words by semicolons) innovative venting; plumbing; plumbing renovation; rehabilitation; vents for plumbing

\section{AVAILABILITY}

[X] Unlimited

For Official Distribution. Do Not Release to NTIS

Order From Superintendent of Documents, U.S. Government Printing Office, Washington, D.C. 20402.

14. NO. OF PRINTED PAGES

94

15. Price

[X] Order From National Technical Information Service (NTIS), Springfield, VA. 2216I

$\$ 10.50$ 


